\section{Pacific Northwest}

National Laboratory

Operated by Battelle for the

U.S. Department of Energy

\title{
ImBuild II: Impact of Technologies on Energy Efficiency Programs
}

\author{
M.J. Scott \\ J.M. Roop \\ R.W. Schultz
}

June 2002

Prepared for the U.S. Department of Energy under Contract DE-AC06-76RL01830 
PNNL-13926

\title{
ImBuild II: Impact of Technologies on Energy Efficiency Programs
}

\author{
M. J. Scott \\ J. M. Roop \\ R. W. Schultz
}

June 2002

Prepared for

the U.S. Department of Energy

under Contract DE-AC06-76RL01830

Pacific Northwest National Laboratory

Richland, Washington 99352 


\section{Summary}

This version of IMBUILD represents the "next generation" of the previously developed spreadsheet based IMBUILD version that was developed in the Excel 7 programming environment. More specifically, a special-purpose version of the Benchmark national I-O model was designed specifically to estimate the employment and income effects of building and other Office of Energy Efficiency and Renewable Energy (EE) developed energy-saving technologies. In comparison with the previous version of IMBUILD, this version allows for more complete and automated analysis of the essential features of energy efficiency investments in buildings, industry, and the electric power sectors. IMBUILD II is also easier to use than extant macroeconomic simulation models and incorporates information developed by each of the EE offices as part of the requirements of the Government Performance and Results Act. While it does not include the ability to model certain dynamic features of markets for labor and other factors of production featured in the more complex models, for most purposes these excluded features are not critical. The analysis is credible as long as the assumption is made that relative prices in the economy would not be substantially affected by energy efficiency investments. In most cases, the expected scale of these investments is small enough that neither labor markets nor production cost relationships should seriously affect national prices as the investments are made. The exact timing of impacts on gross product, employment, and national wage income from energy efficiency investments is not well-enough understood that much special insight can be gained from the additional dynamic sophistication of a macroeconomic simulation model. Thus, we believe that this version of IMBUILD is a cost-effective solution to estimating the economic impacts of the development of energy-efficient technologies. 



\section{Contents}

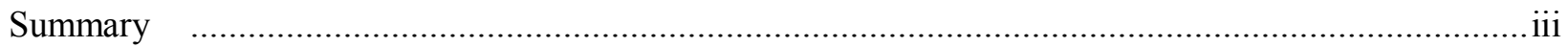

1.0 Introduction: A Method for Assessing Economic Impacts of Energy-Efficient Technologies ......... 1.1

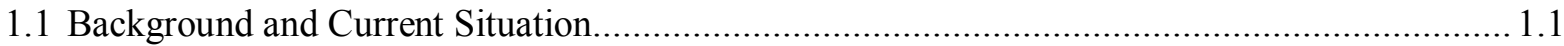

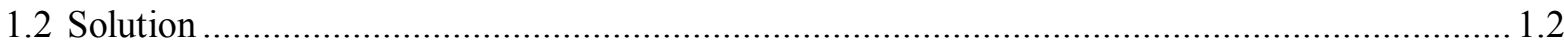

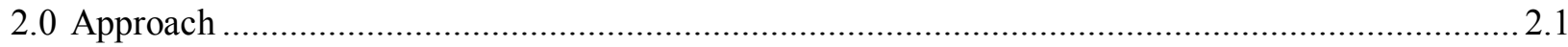

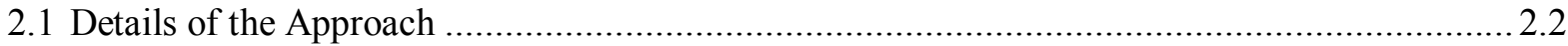

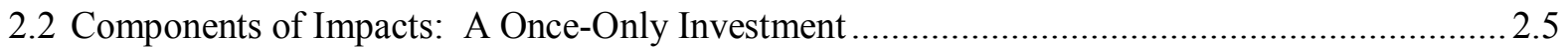

3.0 ImBuild II Model Results for Example BTS Programs .......................................................... 3.1

3.1 Comparison of Capital and Operating Cost Scenarios for Example Technologies ..................... 3.1

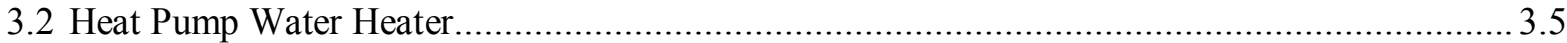

3.3 EPACT (Commercial Air Conditioning) Efficiency Standards.......................................... 3.11

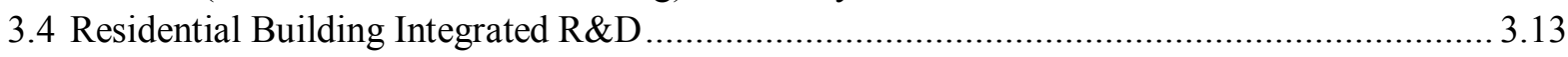

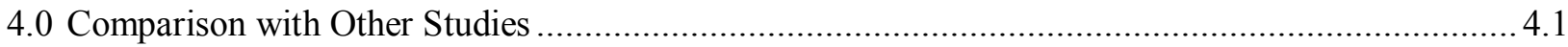

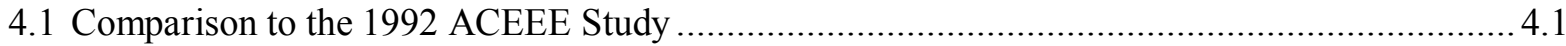

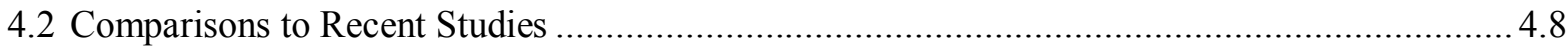

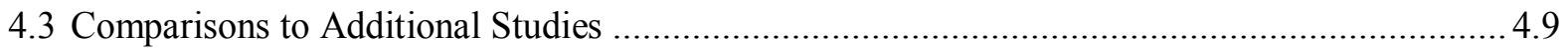

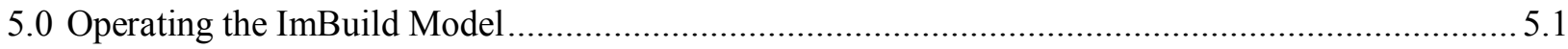

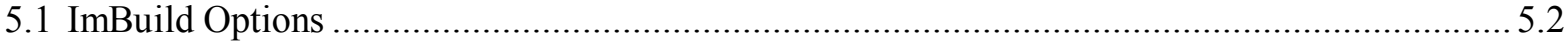

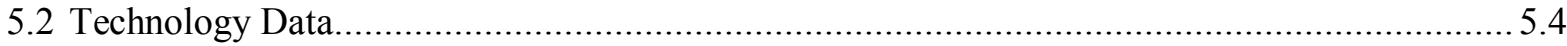

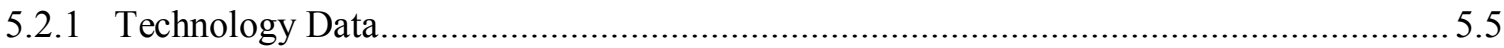

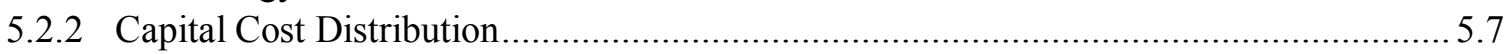

5.2.3 Energy and Water Cost Savings Distribution ........................................................ 5.7

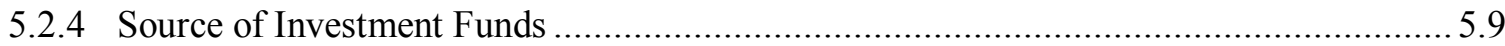

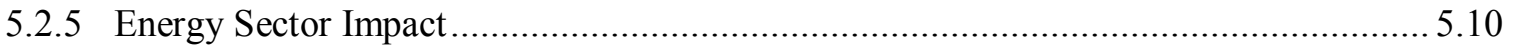

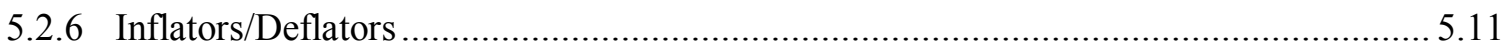

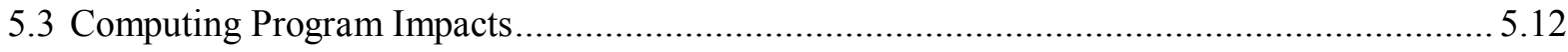

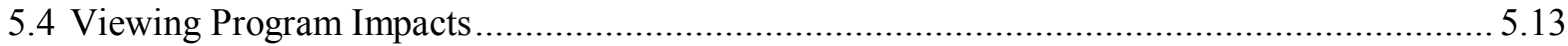

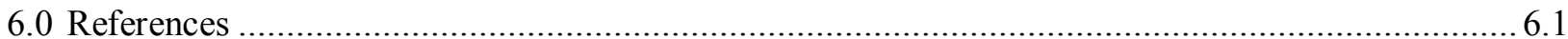

Appendix A - Base Cases for Building Energy Efficiency Technologies ......................................... A.1

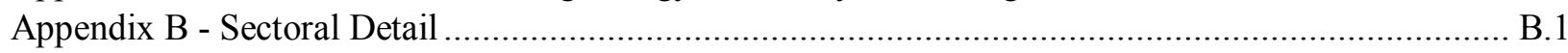

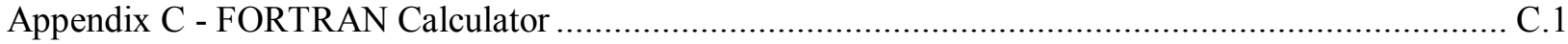

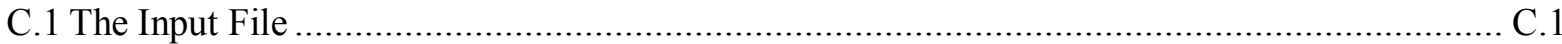

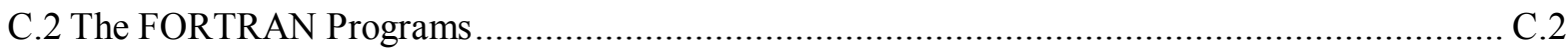

C.2.1 The Main Program, IBLDCALC ......................................................................... .2

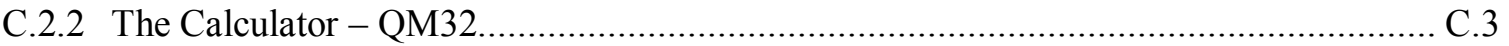




\section{Figures}

2.1 Process for Analyzing Economic Impact of Energy Efficiency Programs................................2.1

2.2 Detailed Calculations of the ImBuild II Model ................................................................... 2.3

2.3 Impact on National Employment of a Hypothetical Once-Only Investment in Appliance Efficiency.

3.1 Incremental Capital Costs by Year for GPRA Metrics Market Scenarios of Heat Pump Water Heater, EPACT Efficiency Standards, and Residential Building Integration R\&D ............ 3.2

3.2 Value of Energy Savings by Year Relative to Baseline for GPRA Metrics

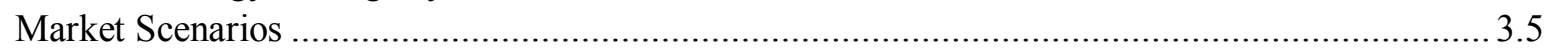

3.3 Employment Impacts of Investment in Heat Pump Water Heaters ............................................. 3.6

3.4 Effect of HPWH Financing on Employment .......................................................................... 3.8

3.5 Impact of HPWH Investment on National Wage Income .......................................................... 3.9

3.6 Sensitivity of Impacts on National Wage Income to HPWH Investments ..................................... 3.10

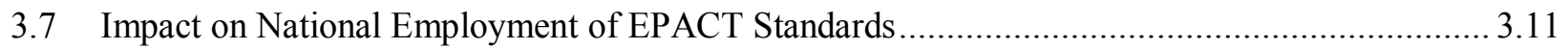

3.8 Impact of EPACT Standards Energy Savings on National Wage Income ................................. 3.12

3.9 Impact of Building America Energy Savings on National Employment ................................. 3.13

3.10 Impact of Building America Energy Savings on National Wage Income................................ 3.14

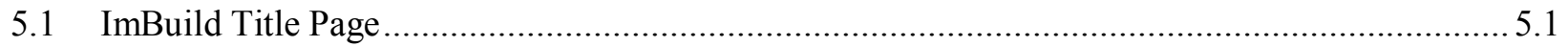

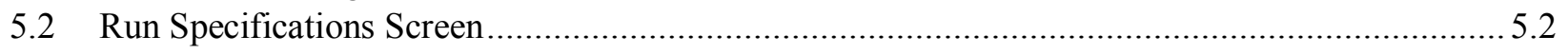

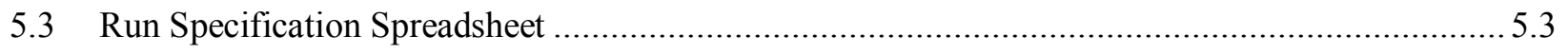

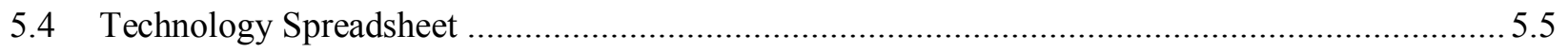

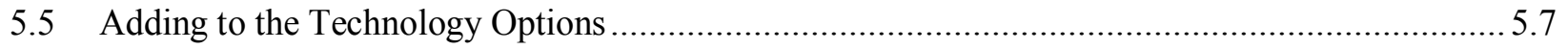

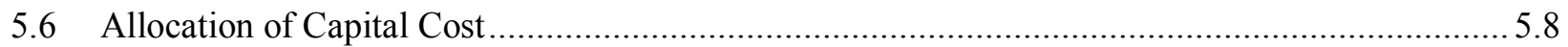

5.7 Energy Cost Savings Distribution Across Sectors ............................................................... 5.9

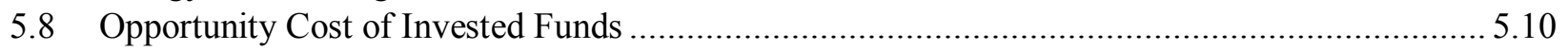

5.9 Impact of Energy Savings on Energy Sector Investments ............................................. 5.11

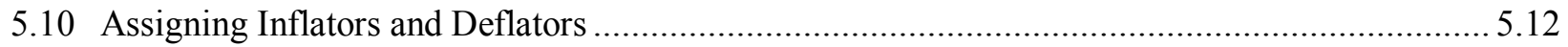

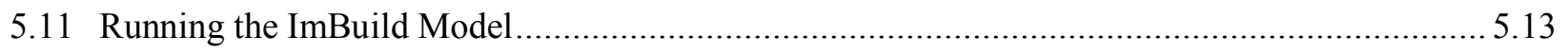

5.12 Report Manager Screens for Output (Graphical Display) .................................................. 5.14

5.13 Report Manager Screens for Output (Table Display) ...................................................... 5.15

\section{Tables}

4.1 Comparison of Output and Employment Multipliers for the ACEEE Version of IMPLAN and ImBuild II Model.

4.2 Comparison of the Impact on Gross Output of a Hypothetical \$100 Investment in New

Energy-Efficient Electric Motors Within the Pulp and Paper Industry (ACEEE Version of IMPLAN vs. ImBuild)

4.3 Economic Impact of High Efficiency Investments in the Residential and Commercial Buildings Sectors on the U.S. Economy 


\subsection{Introduction: A Method for Assessing Economic Impacts of Energy-Efficient Technologies}

\subsection{Background and Current Situation}

As part of measuring the impact of government programs in improving the energy efficiency of the nation's building stock, the U.S. Department of Energy's Office of Building Technology, State and Community Programs (BTS) is interested in assessing the economic impacts of these programs, specifically upon national employment and wage income. As a consequence, BTS funded Pacific Northwest National Laboratory (PNNL) to develop a simple-to-use method that could be used in-house to estimate economic impacts of individual programs. After surveying three fundamental methods available to estimate employment and wage income impacts for selected energy efficiency improvements in the U.S. economy (multipliers input-output (I-O) models, and macroeconomic simulation models), the I-O approach was selected for the original version of ImBuild. (For an overview of each of these approaches, see the previous documentation in Scott, Hostick, and Belzer 1998).

This version of ImBuild uses essentially the same methodology as the previous version, but greatly expands the scope of the model to include more industrial sectors of the economy and thus covers a wider array of buildings technologies. By covering more industrial sectors, the model lends itself to assessing the impacts of evaluating technologies developed outside the BTS scope, including power technologies, industrial technologies and transportation technologies. The major differences between this version and the previous version of ImBuild are:

- The Visual Basic-EXCEL environment has been replaced with a Visual Basic (VB) program that assembles, accesses, and stores data in Access data files.

- The Input-Output structure is based on the 1992 Benchmark U.S. table, ${ }^{(a)}$ specially aggregated for this project to 98 sectors rather than the previous 35 -sector model.

- The manipulation of this larger I-O structure is done by a VB call to a FORTRAN program that returns the results to the VB program where the results are transformed into graphics and stored in Access files.

The model remains a static input-output model, which allows a great deal of flexibility concerning the types of energy efficiency effects that can be accommodated. Certain economic effects of energy efficiency improvements require an assessment of inter-industry purchases. As an example, some "energy efficiency" investments will not only reduce the costs of energy but the costs of labor and other goods and services as well. In the language of economics, this represents an investment-specific increase

(a) Ann M. Lawson, "Benchmark Input-Output Accounts of the U. S. Economy, 1992: Make, Use and Supplementary Tables," Survey of Current Business, November, 1997, pp. 36-82. 
in productivity and value-added ${ }^{(a)}$ and a change to the input-output structure, differing from a case in which a constant I-O structure is applied to a change in investment. Yet, this effect is at the heart of many investment decisions. Savings in the energy, labor, materials, and services from improved productivity are the source of subsequent rounds of investment and economic growth.

I-O models such as this one can be used to estimate the impact of changes in overall efficiency and productivity in the economic sectors that make energy-efficiency investments. In contrast to the previous version of ImBuild, which was designed only to estimate the impacts of energy efficiency in residential and commercial buildings, ImBuild II could apply to an investment by a paper mill in more energyefficient equipment, the investment by an electric utility in more efficient plant, or improvements in transportation infrastructure. An input-output model also can keep track of the potential increases in value added that result from the improvement in efficiency and can, with appropriate assumptions, calculate the macroeconomic effects associated with spending of this increased income.

While this model has been greatly expanded in its capabilities, it retains its user-friendly shell that makes it easy to use, with the advantage that it provides more theoretically plausible and comprehensive results than alternative models.

The chief drawbacks of this, or any I-O models, are that 1) they do not provide information on the timing of impacts (for example, they do not say how long an investment in efficiency will take to work its way through the economy), and 2) because no prices or explicit behavioral adjustment mechanisms are found in I-O models, no internal market features are present, such as increasing prices for sector output or for factors of production that automatically limit the size of impacts. In an I-O model, it is assumed that inputs needed for production in each sector are available without limit in constant proportions at constant unit cost. Thus, when analyzed in an I-O model, even very large scale investments that increase the scale of an industry many times over would not encounter either labor or material shortages that might cause prices to rise in the real world and dampen the economic response.

While we acknowledge these drawbacks, the scale of most energy-efficiency improvements, relative to the overall economy, are small enough to make this an inconsequential effect.

\subsection{Solution}

The programmatic needs of BTS suggest that a simple, flexible, user-friendly method is needed to derive national employment income and output impacts of BTS programs. A special-purpose version of an I-O model was designed specifically to estimate the employment, income, and output effects of building and other EE energy technologies. This model retains its original name, Impact of Building Energy Efficiency Programs (ImBuild ), though the new version (ImBuild II) can now handle energy efficiency improvements of almost any sort. In comparison with alternative models, ImBuild II allows for more complete and automated analysis of the essential features of energy efficiency investments.

(a) Value-added is the difference between the value of the output of a sector and the costs of the purchased goods and services that go into the sector. It is mainly composed of labor and proprietor income, retained earnings of corporations, rents, and taxes. 
ImBuild II is also easier to use than extant macroeconomic simulation models. It does not include the ability to model certain dynamic features of markets for labor and other factors of production featured in the more complex models, but for most purposes these excluded features are not critical. The analysis should be credible as long as the assumption is made that relative prices in the economy would not be substantially affected by energy efficiency investments. In most cases, the expected scale of these investments is small enough that neither labor markets nor production cost relationships should seriously affect national prices as the investments are made. The exact timing of impacts on gross product, employment, and national wage income from energy efficiency investments is not well-enough understood that much special insight can be gained from the additional dynamic sophistication of a macroeconomic simulation model. Thus, we believe that ImBuild II is a cost-effective solution to the problem at hand. 


\subsection{Approach}

The macroeconomic impacts of BTS programs can be analyzed using the following 4-step process, illustrated in Figure 2.1. The first three steps are conducted as part of the normal GPRA Metrics process; however, the fourth step (calculating the economic impacts) has been automated. The process uses a version of the Benchmark U.S. national I-O table incorporated in a Visual Basic program that controls processing in a FORTRAN impacts calculator. The goal of the model-building process was to create a computerized tool that required only a knowledge of ImBuild II technologies to run. The national I-O model is a 98- x 98-sector version of the 498- x 498- sector benchmark U.S. Input-Output table for 1992. The 98 sectors are those most important for analyzing economic impacts of residential and commercial buildings technologies, but is comprehensive enough to cover other energy-efficient technologies as well. ImBuild II is a particularly easy model to use, and was made even easier by the creation of an inexpensive, user-friendly front end to facilitate user inputs. Dialog boxes and spreadsheet-like data entry screens create this user-friendly front end. Thus, the project provides an analytical tool that BTS policy analysts can use without having to be programming experts.

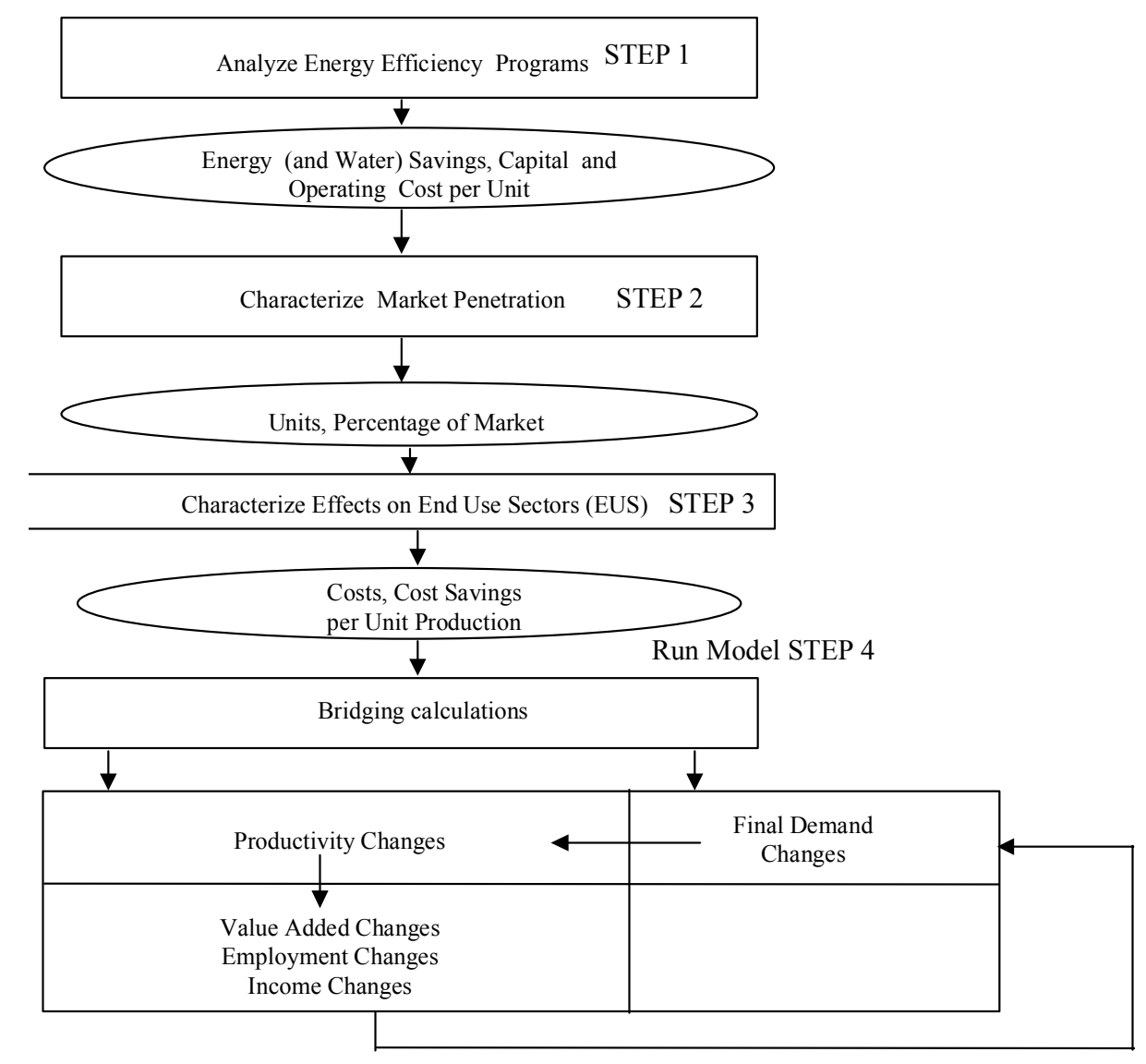

Figure 2.1. Process for Analyzing Economic Impact of Energy Efficiency Programs 


\subsection{Details of the Approach}

\section{Step 1. Identify Program Economic Characteristics}

To analyze existing BTS programs, a set of assumptions must be developed concerning the effects in the marketplace when more efficient technologies are developed or adopted as a result of the programs. The relevant program information includes: size of the incremental investment in the technology over time compared with the conventional technology it replaces, corresponding extra energy savings by fuel type in physical and monetary terms (may include additional use of some fuels when one type of fuel replaces another), and non-energy operations savings (if any) in comparison with current (conventional) technology. Sufficient information of this type currently exists on many, if not most, of the BTS programs as a result of the GPRA Metrics process. Three technologies are used as examples in this report. They were chosen to demonstrate different types of BTS programs, as well as some related macroeconomic issues.

- Residential Heat Pump Water Heater. The purpose of the DOE program in this area is to develop and commercialize highly efficient water heaters. The technology is expected to displace the next generation of already highly-efficient conventional water heaters.

- EPACT Commercial Building Standards-Air Conditioning. The DOE program is continuing the development of efficiency standards for commercial air conditioning that will improve the comfort and reduce the cost of air conditioning commercial retail and office space.

- Residential Buildings Integration $R \& D$. The final technology is Residential Buildings Integration $\mathrm{R} \& \mathrm{D}$, a program that seeks to improve the energy efficiency of new factory-built, modular, manufactured, and small-volume site-built homes by use of systems engineering concepts, new products, and new processes.

Together, these examples demonstrate the impact of programs aimed at residential technology development, programs aimed at commercial technology development, and programs aimed at integration of energy efficiency knowledge and products into building systems.

\section{Step 2. Characterize Market Penetration of the New Technologies}

Existing research of the BTS market niche is used to characterize market penetration of the new technologies. Analysis depends on input from the GPRA Metrics program.

\section{Step 3. Characterize Effects of the BTS Programs on End Use Sectors (Residential and Commercial Buildings)}

Effects of the program on the end-use sectors, utilizing the technology or results of the program, must be characterized. This step combines analysis from Steps 1 and 2. A bridging matrix is used to match buildings and equipment investments in end-use sectors (for example, classes of commercial buildings) to 
the economic sectors that construct, operate or occupy these buildings. This process is necessary because, although the BTS programs are organized around buildings, equipment types and end uses, I-O models use economic sectors organized according to Standard Industrial Classification (SIC) codes. For purposes of the empirical analysis in this report, economic sectors occupying commercial buildings are assumed to experience savings in proportion to their baseline expenditures on energy and building maintenance goods and services.

\section{Step 4. Calculate Economic Impacts}

Given the data developed in Steps 1 through 3, the ImBuild II model then calculates the impacts of energy efficiency programs on employment in the following three substeps.

\section{Initial Investment Impacts}

First, the model calculates the income and employment effects of initial spending on energy efficiency investments. (These impacts include the initial spending on plant and equipment by businesses and households that adopt the new energy-efficient equipment and practices. The impact of spending by the BTS programs on services provided in government, universities, and other contractors is not computed.) In an I-O model, this impact is estimated by changing expenditure levels in the government, household, and business investment columns of final demand and productivity in the last box of Figure 2.1. The left-hand side of Figure 2.2 illustrates the necessary calculations in more detail. The household and business investments are estimated, based on Step 2, then allocated to business sectors through the bridging calculations.

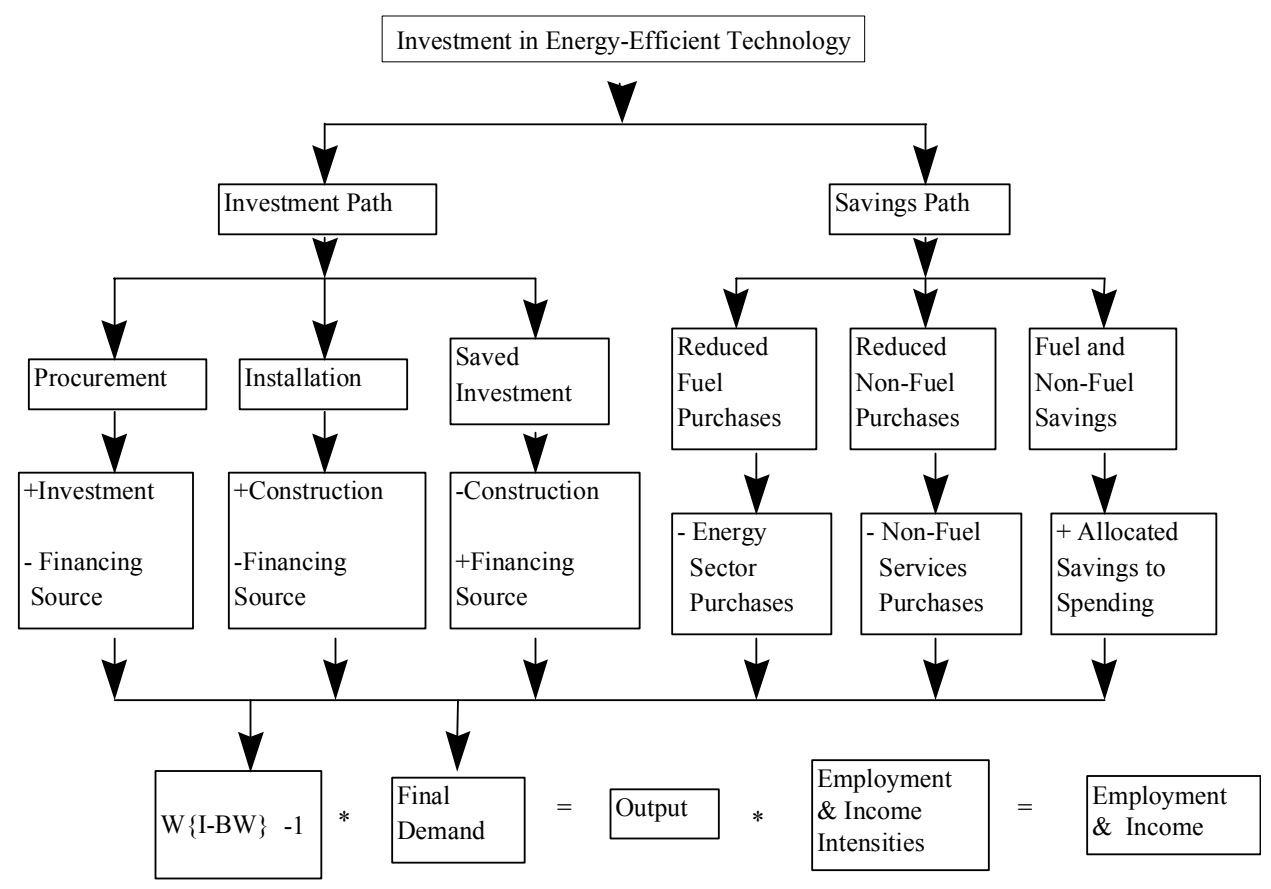

Figure 2.2. Detailed Calculations of the ImBuild II Model 
An important finding of this project is that the size and algebraic sign of the employment impacts of the initial investment process can depend critically on project financing. The investment typically must be paid for by diverting resources elsewhere in the economy. Therefore, the net employment impact of these energy-saving investments depends not only on the labor intensity of the investment process itself, but also on the relative labor intensities of those investment and consumption processes from which the necessary investment resources are diverted. As shown in Section 3.0, the positive impact of the initial capital investment is dampened considerably and may be reversed after the opportunity cost of the investment funds is taken into account.

\section{Calculate Impact of Energy Savings on Value Added and Residential Savings}

ImBuild II calculates economic savings associated with changes in the use of energy, labor, and materials with the improved technologies and practices. In the case of residential applications this is relatively straightforward, because residential savings are assumed to be recycled into final demand. For commercial building applications, the process is more complicated because the interindustry relationships between specific sectors are affected, not just final demand. For example, if the commercial building saves electricity, the business sectors operating/occupying these buildings would have lower purchases from the electric utility industry per dollar of output; thus, the coefficients in the utility industry row of the input/output structure of the economy must be reduced. Results from Step 3 are inserted into the ImBuild II model in the interindustry portion of the I-O table (shown as Productivity Changes in the last box of Figure 2.1); then the model is run with the automatically recomputed table.

Because the energy and maintenance intensity of the commercial sector changes, the coefficients of the I-O structure are automatically recalculated at each time step. This re-computation process requires less than 1 second on a Pentium 500 MHZ personal computer.

The financial impacts of energy and non-energy savings (for example, savings in building maintenance) are computed by the model. These savings are treated as free income that is available to be saved or invested by the sector collecting the income.

The energy and non-energy savings do not affect employment in the national economy until they are reinvested or spent. For purposes of the analysis conducted for this report, the increments to value added (savings) are assumed to be allocated to compensation of labor and capital and to business taxes in the same proportion as all other value added in each sector. Then, the income of these sectors is assumed to be spent on final demand in the same proportion as existing compensation of labor, capital, and government. That is, if a given sector has $1 \%$ of all personal consumption expenditures in the economy and a $0.7 \%$ share of all business fixed investment, the sector will receive these same percentage shares of the efficiency-related increase in spending. Similarly, if labor compensation represents $70 \%$ of the baseline total value added in an industry, labor will receive $70 \%$ of any energy savings in that industry. Finally, labor compensation, business profits, and taxes are allocated to consumption, investment, and government spending according to current proportions. 


\section{Calculate Economic Impact of Value Added and Residential Savings}

ImBuild II accumulates the energy and non-energy savings in the residential buildings sector and the value-added changes associated with energy and non-energy savings within the commercial buildings (or industrial or transportation) sector. The model then calculates spending impacts associated with these savings by proportionately increasing final demand across all sectors as noted, while at the same time reducing final demand in the sectors that supplied the saved resources. This step accounts for the spending associated with the monetary savings and improvements in technological efficiency and for the associated shift from energy to non-energy spending. It also accounts for changes in the patterns of economic activity in the economy, due to technological changes caused by the BTS programs (for example, in retailing less electricity is used per dollar of output because of more efficient lighting). ${ }^{(a)}$

ImBuild II collects the estimates of the initial investments, energy and non-energy savings, and economic activity associated with spending of the savings (increases in final demand in personal consumption, business investment, and government spending), and provides overall estimates of the increase in national output for each SIC sector using the adjusted I-O matrix. Finally, the model applies estimates of employment and wage income per dollar of economic output for each sector and calculates impacts on national employment and wage income.

When finished, the results of ImBuild II model runs can be saved by running an imbedded dialog designed for this purpose.

\subsection{Components of Impacts: A Once-Only Investment}

Energy conservation technology affects the activity level of the U.S. economy through three primary mechanisms. First, if the incremental capital costs of the new technology per installed unit are different than those of the conventional technology, changes in final demand will occur in the sectors involved in manufacturing, distribution, and installation for both technologies, changing the level of overall economic activity. ${ }^{\text {(b) }}$ Second, depending on how the efficiency investment is financed, it may "crowd out" other domestic saving, investments, and consumer spending, somewhat reducing overall economic activity. Third, energy and non-energy expenditures are reduced. On the one hand, this reduction lowers final demand in the electric and gas utility sectors, as well as the trade and services sectors that provide

(a) ImBuild II does not account for all of the long run impacts of technological change. The change in energy using capital in the commercial sector would alter the marginal value of all of the factors of production (including labor and capital) and would induce a rearrangement of capital and labor that ultimately results in an increase in output and in final demand. We show part of this effect, that of the initial spending associated with the savings, but not the effect of increased capital stock that would be created by the investment portion of the spending. Most economic models, including many dynamic simulation models, do not completely reflect the effect of capital accumulation and growth in capacity on final output and employment.

(b) Frequently, a premium is present in the cost of appliance purchase and installation, over and above the cost of an alternative conventional system. We have assumed the premium attached to the new technology is due entirely to the differential cost of manufacturing the equipment. Distributor and dealer/installation costs are assumed to be unaffected. 
maintenance, parts, and services. On the other hand, it increases net disposable income of households and businesses and increases general consumer and business spending in all sectors (including some increases in expenditures for electric and gas utility services and retail trade and services).

Figure 2.3 demonstrates how these mechanisms work by showing the effect of a hypothetical onceonly investment in residential energy conservation technology in the ImBuild II model. It is assumed that consumers spend a premium of $\$ 100$ million on more-efficient residential appliances in the year 2000 that each year thereafter saves $\$ 15$ million of electricity, $\$ 30$ million in natural gas, and $\$ 5$ million building maintenance expenditures, for annual savings of $\$ 50$ million. This $\$ 50$ million annual savings yields a simple payback period of 2 years. The first two cases in Figure 2.3 show only the employment effects of the $\$ 50$ million savings. In the first case, the savings are confined to the residential sector. The second case shows how the impacts would change if these energy savings had instead been experienced in the commercial sector, where the savings are initially experienced as an increase in the profitability of those businesses saving the energy. These profits are assumed to be recycled in the economy as spending by workers, spending by the firms themselves, and by governments experiencing increases in tax collections. In the first case, the energy savings in the residential sector of $\$ 50$ million have a net impact on the U.S. economy of about 306 jobs, or about 0.6 additional jobs per $\$ 100$ thousand dollars of direct energy savings. The impact is virtually identical if the energy savings occur in the commercial sector, because the employment intensity of the spending mix of businesses, their workers, and government associated with commercial savings is only slightly different from the spending intensity of the household sector alone, which is associated with residential savings.

Next, Figure 2.3 adds a third and fourth case to show the employment impacts of the $\$ 100$ million investment itself. The third case shows the impact of the investment premium. In this case, even though investment in the technology itself generates employment, the short run net employment impact is negative (minus 200 jobs) because the opportunity cost of the investment premium is the dollar amount the investment would have produced elsewhere in the U.S. economy, which on average is more laborintensive than the manufacturing sector that makes the new technology. ${ }^{\text {(a) }}$ Typically, efficiency programs are considered relatively labor-intensive, but this is not always the case. Heating and air conditioning manufacture, for example, is quite capital-intensive. The strength and direction of the investment effect depends on the size of the investment premium and its combined domestic U.S. direct and indirect labor intensity, relative to that of other domestic spending (the opportunity cost of the investment). For the employment impact of the investment to be positive, the sectors supplying the new technology must on average create more domestic jobs per dollar of spending than does other domestic spending. An extreme form of this positive investment effect would occur, if the investment were financed internationally (that is, no domestic opportunity cost is included). This is the fourth case in Figure 2.3, which shows a shortrun jobs impact of more than 1700 and a long-run jobs impact of 300 . The fourth case also corresponds to many regional analyses that have been made of energy conservation impacts, where the investment funds are assumed to come from somewhere else and have no opportunity cost in the region.

(a) Strictly speaking, the labor intensity that counts is the employment, direct and indirect, that is created by each dollar of spending. Thus, it is theoretically possible for a capital-intensive industry to buy lots of laborintensive inputs from other industries and the total effect to be labor intensive as a result. 


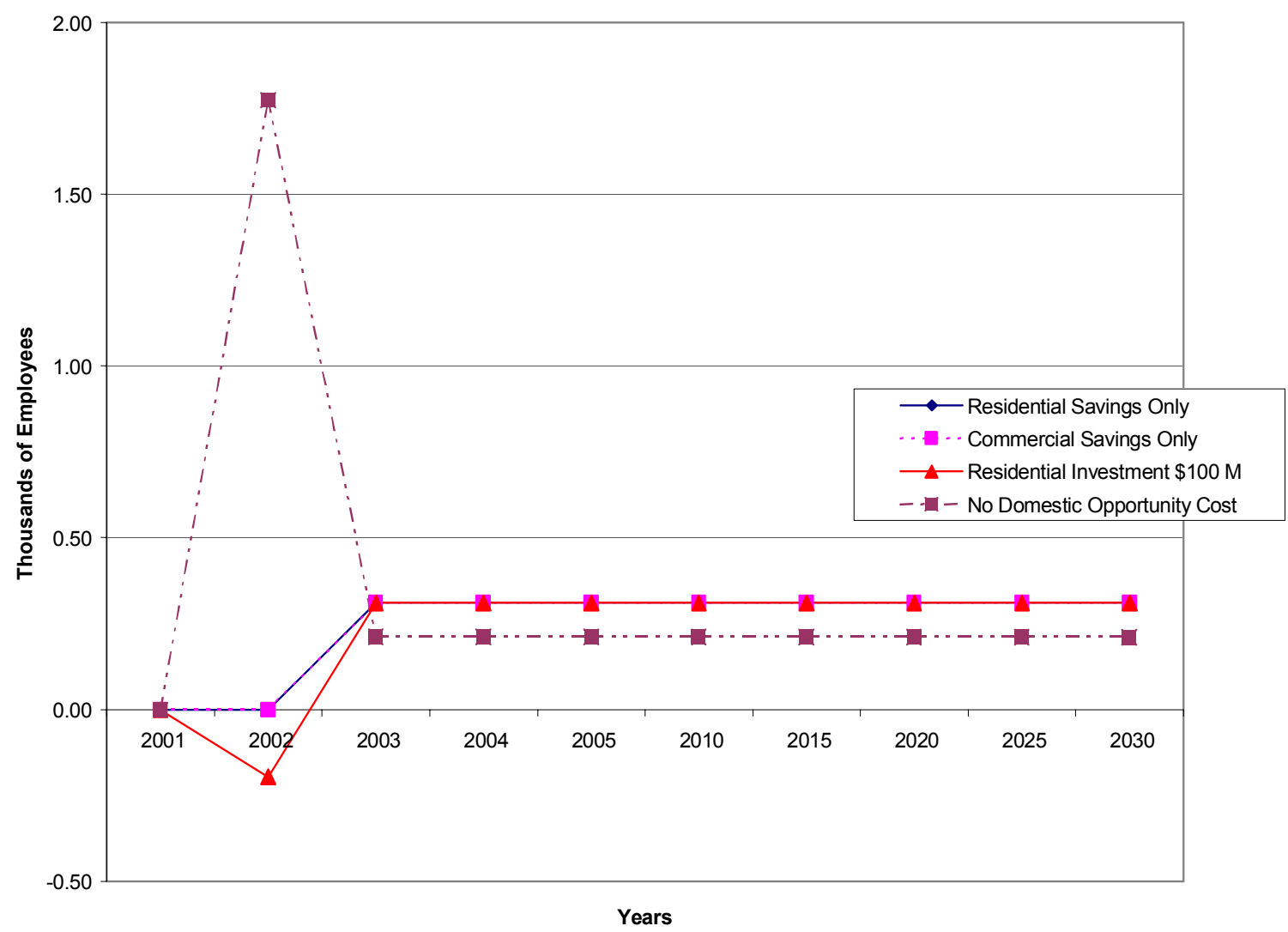

Figure 2.3. Impact on National Employment of a Hypothetical Once-Only Investment in Appliance Efficiency 


\subsection{ImBuild II Model Results for Example BTS Programs}

This section discusses the results obtained by using the ImBuild II model to calculate the employment and income consequences of three specific building technologies as they are expected to be introduced into the U.S. residential and commercial buildings sectors. The three technologies were chosen because they represent a diversity of BTS program characteristics, are likely to affect the economy in different ways, and illustrate a number of issues concerning the economic impact of building technologies.

\subsection{Comparison of Capital and Operating Cost Scenarios for Example Technologies}

The impact of BTS technologies on the national economy depends on the market penetration of these technologies and their associated investments and operating costs. This analysis is tied to the scenarios for market conditions, costs, and energy consumption of specific technologies and programs from the BTS GPRA Metrics, a product of significant work on technology performance, costs, and markets. ${ }^{\text {(a) }}$ Appendix A shows the specific values of these savings and expenditures for the specific scenarios of market penetration. Figure 3.1 shows the premium in capital costs for the GPRA Metrics market penetration scenarios associated with three programs: Emerging Technology R\&D on heat pump water heaters, EPACT Energy Efficiency Standards, and Residential Buildings Integration R\&D. These choices illustrate three basic types of BTS programs: an equipment R\&D program (focused on the residential sector), an equipment efficiency standards program (focused on the commercial sector), and a systems and education program. Descriptions of these programs follow.

Heat Pump Water Heaters. The first program is Emerging Technology R\&D on the heat pump water heater (HPWH) and other follow-on technologies. The purpose of this program is to commercialize highly efficient water heaters for new and existing manufactured and single-family residential buildings. The general program seeks comprehensive solutions for water heating consumption (low cost heat pump water heaters, condensing gas water heaters, waste heat recovery, and water conservation devices), and wants them well established in the market. Long-term goals include HPWHs being sold at a rate of $50,000 /$ year in five years (currently, the volume is about 2,000/year). The program would like to see an increased likelihood of HPWH standards/building codes in the 2010 to 2020 timeframe, introduction of gas condensing residential gas water heaters, and increased likelihood of future standards. Near-term milestones include: market introduction of a low cost HPWH (less than \$600) by the end of 2003, establishment of HPWH advocacy group with DOE funding for 3 to 5 years, and market introduction of residential gas condensing water heaters by 2005 . Estimated markets are:

- HPWH: Target market of 13.6 million existing homes of the 36 million home potential with electric resistance water heaters, and approximately $40 \%$ of new homes. Limited but initial market for light commercial.

(a) This report used BTS program data reported in the BTS GPRA Metrics Estimates, FY03 Budget Request, December, 2001, as well as program information from PNNL (2002) that PNNL updated by and with DOE/EE program managers to produce the descriptions shown here. 


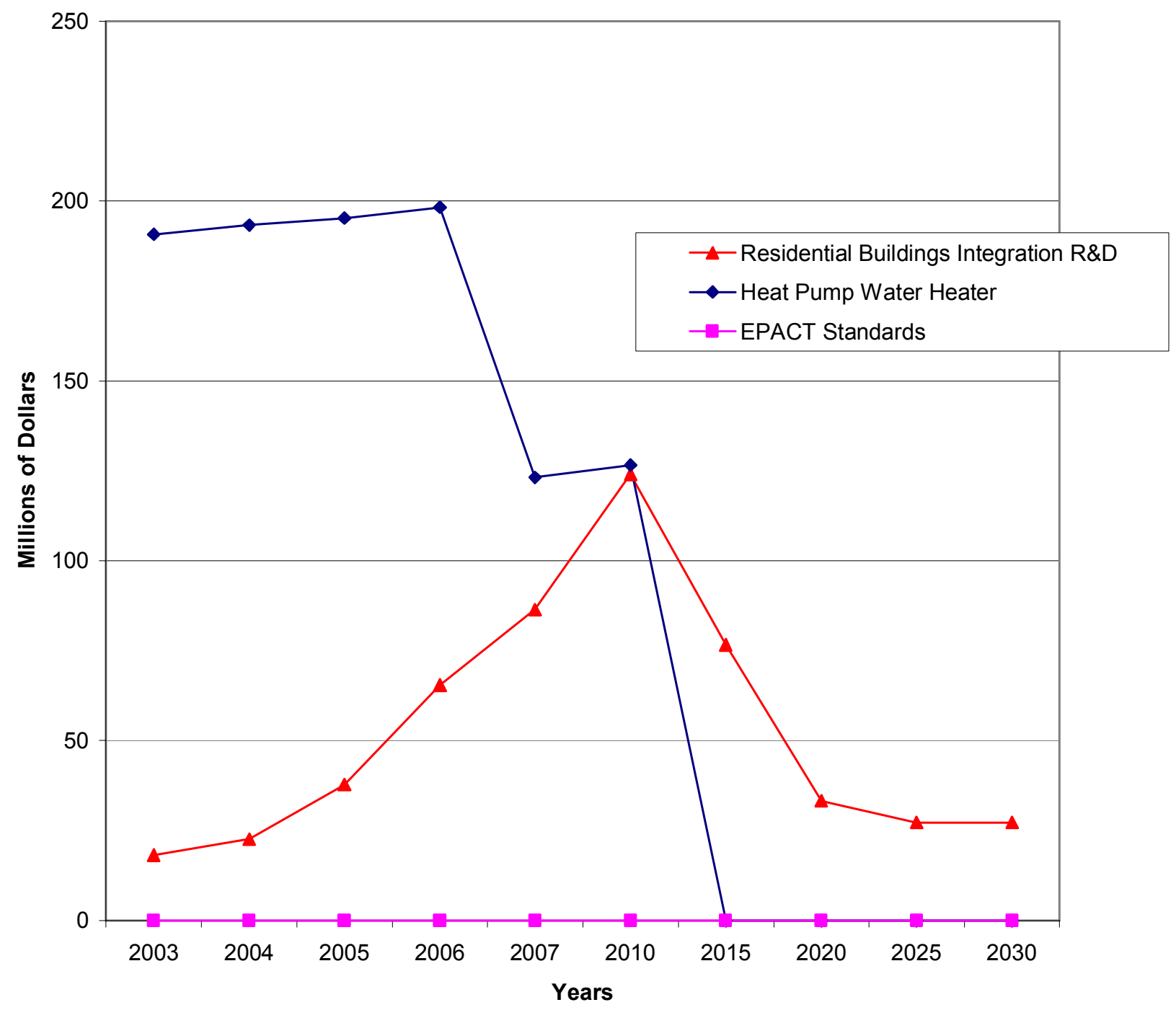

Figure 3.1. Incremental Capital Costs by Year for GPRA Metrics Market Scenarios of Heat Pump Water Heater, EPACT Efficiency Standards, and Residential Building Integration R\&D

- Condensing Gas Water Heaters: Target market of approximately 20 million existing homes of the over 60 million homes potential, and about $40 \%$ of new homes.

About $50 \%$ of the program funds are spent on $\mathrm{R} \& \mathrm{D}$, and about $50 \%$ on market transformation activities.

\section{Heat Pump Water Heater}

Market introduction: 2004

Performance Target: 2.00 Energy Factor (demonstrated)

Sales Target:

More aggressive sales target by 2015 (currently 6\%) - perhaps 10\% (building codes expected to help by excluding electrical resistance $\mathrm{WH}$, as will be case in California)

Installed cost: $\quad$ Initial installation cost of $\$ 700$ dropping to $\$ 650$ in 2010 


\section{Residential Gas Condensing Water Heater \\ Market introduction: 2005 \\ Performance Target: $\quad$ Energy Factor of 0.80 \\ Penetration Target: $\quad 9-10 \%$ by 2020 \\ Installed Cost: $\quad$ Assume $\$ 350$ base cost, new WH will have an incremental cost of $\$ 150-\$ 200$}

EPACT Energy Efficiency Standards. The second program is EPACT Energy Efficiency Standards. The DOE program is continuing the development that will make a number of types of commercial space conditioning and other equipment commercially feasible. The mission of the overall lighting and appliance standards program is to achieve significant energy savings, consumer cost savings, and reduced air emissions through standards rulemaking.

The program also prescribes test procedures that measure energy efficiency and energy use and provide an estimate of the annual operating cost of each appliance.

The long-term goal of the program is the setting of efficiency standards that lead to substantial increases in the average efficiency of new building equipment. The assumption for GPRA is that work will continue in FY2003 for products for which cost-effective additional energy savings may be large. For this version of the GPRA process, these products include boilers, three-phase residential-size cooling equipment, PTAC and PTHP equipment, and large rooftop AC equipment. Major near-term milestones include publishing a Notice of Proposed Rulemaking for certain ASHRAE 90.1-1999 products (commercial HVAC and water heating equipment); for medium (1-200 hp) motors, residential furnaces and boilers, dishwashers, and fluorescent and reflector lamps; for residential central air and combination space and water heating appliances; and for plumbing products, pool heaters, and direct heating equipment.

Three basic kinds of commercial air conditioning equipment are considered, at various sizes. In general, the goal for these units is to increase their Seasonal Energy Efficiency Rating (SEER) from roughly $8-10$ to around $10-12$ by the year 2008 :

\begin{tabular}{|l|l|l|l|l|l|l|l|}
\hline & \multicolumn{3}{|l|}{ Efficiency (SEER,EER) } & \multicolumn{4}{|l|}{ Energy Savings in Year (TBtu) } \\
\hline Equipment Category & EPCA 92 & New Std & Eff. Date & 2010 & 2020 & 2030 & Cum. \\
\hline 3-Phase S. Package, Air Source AC, $<65 \mathrm{kBtu} / \mathrm{h}$ & 9.7 & 12 & 2005 & 4.6 & 21.0 & 26.5 & 396.0 \\
\hline 3-Phase Split, Air Source AC, $<65 \mathrm{kBtu} / \mathrm{h}$ & 9.7 & 11 & 2005 & 0.9 & 4.1 & 5.2 & 78.1 \\
\hline Central, Air Source AC, $>=65,<135 \mathrm{kBtu} / \mathrm{h}$ & 8.9 & 11 & 2008 & 5.5 & 25.0 & 31.6 & 471.6 \\
\hline Central, Air Source AC, $>=135,<240 \mathrm{kBtu} / \mathrm{h}$ & 8.5 & 11 & 2008 & 5.4 & 24.6 & 31.0 & 463.1 \\
\hline Packaged Terminal AC, $7-10 \mathrm{kBtu} / \mathrm{h}$ & 8.6 & 10.8 & 2008 & 0.4 & 1.8 & 2.2 & 33.3 \\
\hline Packaged Terminal AC, $10-13 \mathrm{kBtu} / \mathrm{h}$ & 8.1 & 10.2 & 2008 & 0.6 & 2.6 & 3.3 & 49.5 \\
\hline Packaged Terminal AC, $>13 \mathrm{kBtu} / \mathrm{h}$ & 7.8 & 9.5 & 2008 & 0.3 & 1.3 & 1.7 & 25.2 \\
\hline
\end{tabular}

Residential Buildings Integration R\&D. The final program is Residential Building Integration $\mathrm{R} \& \mathrm{D}$, which seeks to consolidate the formerly separate systems engineering programs of Building America, Industrialized Housing, Passive Solar Buildings, indoor air quality, and existing building research into a comprehensive program to accelerate the introduction of highly-efficient building technologies and practices through research and development of advanced systems for production builders. The program seeks to improve and change current practices by emphasizing system engineered 
whole-building approaches that integrate component-based research and technology. Long term, the overall program wants to develop advanced systems to improve the energy performance of over 300,000 of the 1 million homes built in 2010. The performance increase will allow the homes to use $50 \%$ less energy for space conditioning and water heating use than typical homes built in 1993.

The program targets new single family, multi-family, and manufactured housing units with over $\$ 25,000$ annual income in all climate zones as well as new single family homes, multi-family infill, Housing and Urban Development (HUD) code homes, and small commercial buildings. Existing homes benefit from new technologies and improved construction practices developed for new homes.

About 1.2 million new housing units are built per year. This is the primary target of Building America. In addition, the program targets 31.1 million existing households with incomes from $\$ 25,000$ to 50,000 per year. (DOE's Weatherization Program targets the lower-income households). The incremental investment is assumed to be about $2 \%$ above conventional construction costs.

Figure 3.2 shows the associated energy and non-energy savings (reduction in operating costs) compared with conventional technologies. All cost premiums and savings are measured relative to baseline conditions by the GPRA Metrics program. These figures represent total increases or decreases in cash outlays in the year shown and not the annualized savings or costs. ${ }^{\text {(a) }}$ Cash outlays vary not only because of the characteristics of the technologies themselves, but also because the market penetration of each technology is expected to change over time as a result of BTS program success.

Capital expenditures shown in Figure 3.1 represent the premium of investment cost over the money that otherwise would have been spent to equip the same residential and commercial building stock with baseline technologies. The costs shown are dependent not only on the cost per unit of the new technology but also on the costs of the technology with which it is assumed to compete. Thus, no cost premium is shown at all for EPACT Standards, which are assumed to result in commercial equipment that is costcompetitive with current equipment, or for shown for the heat pump water heater in Figure 3.1 beyond the year 2010. Conversely, because of variation in the rate of building and relative reduction in costs for new technology over time, Residential Buildings Integration R\&D at first peaks and then declines. The peak occurs as program-related investment grows in size relative to current technology, then declines as program-related investment is overtaken by the advanced technology installation that would have occurred anyway in the absence of the program.

All three programs show significant energy cost savings in Figure 3.2. These cost savings depend on the cumulative number of units installed compared with the same market developed with more conventional technology, the relative amount of energy used or saved, and any additional non-energy costs or savings.

(a) We do this because economic impacts, such as employment, will occur when the money is actually being spent, not when the economic entities incur the costs associated with the spending. Thus, for purposes of this analysis, if an investment is made in the year 2000, the jobs created are the same whether the money to pay the workers is accumulated cash or borrowed funds. The impact of the opportunity cost is more of a question, as financing theoretically could change the time distribution of the impact on the cost side. We have chosen to show the impact as if it all occurred in the same year as the investment in energy efficiency. 


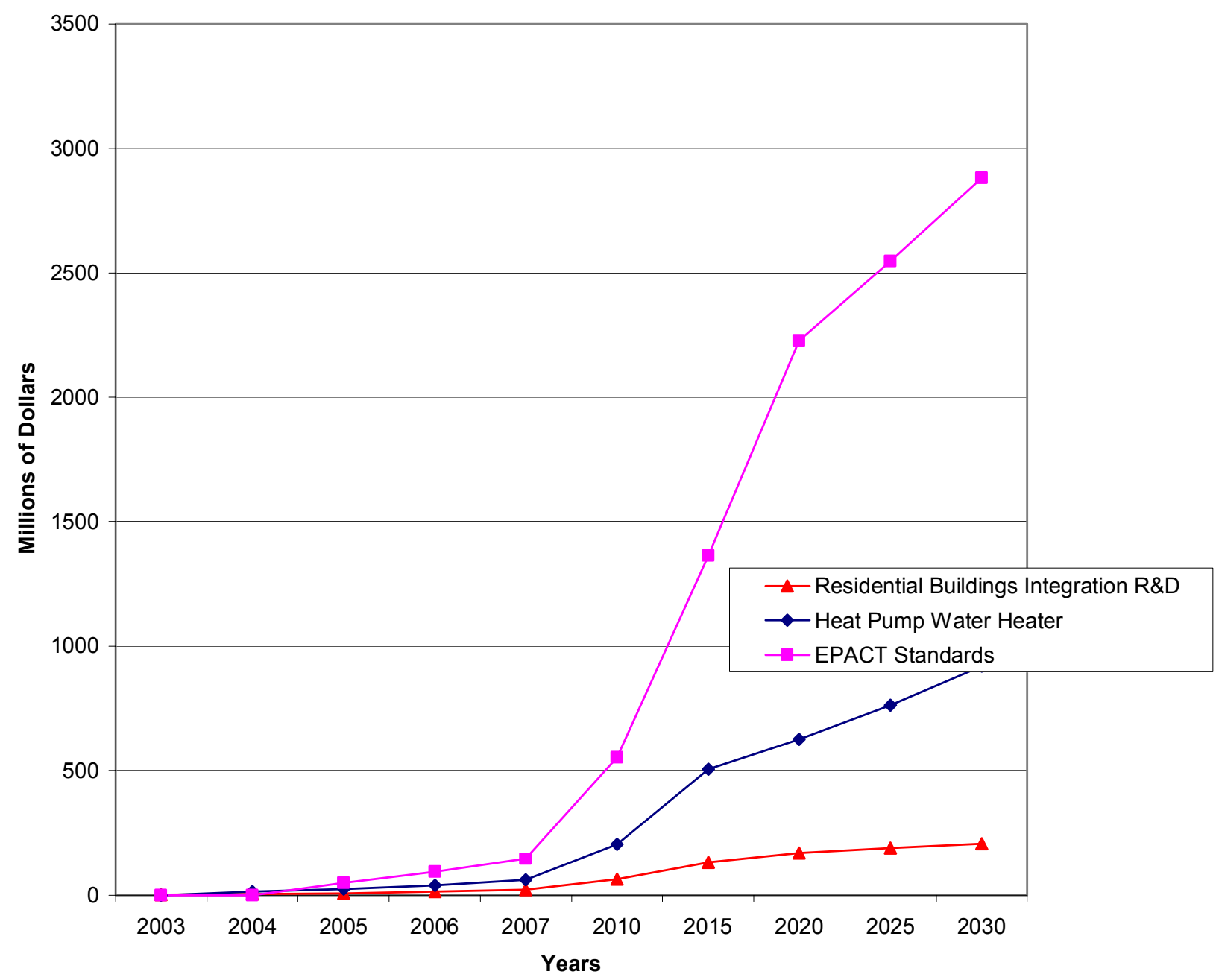

Figure 3.2. Value of Energy Savings by Year Relative to Baseline for GPRA Metrics Market Scenarios

\subsection{Heat Pump Water Heater}

Figure 3.3 shows the employment impacts associated with variations of the GPRA Metrics heat pump water heater scenario. An essential feature of this scenario is the accelerating investment in heat pump water heaters throughout the forecast period out to 2010, with a high level of new investment thereafter. This investment path means that in any time period, the economy is experiencing a mix of consequences from energy savings and new energy efficiency investment, with the prospect that negative investment consequences could dominate. In fact, however, the energy savings dominate. The line in Figure 3.3 marked Energy Savings Only demonstrates that eventually, the energy savings in the scenario could generate a considerable economic surplus with the potential to create up to several thousand jobs. ${ }^{\text {(a) }}$ The Base Case includes the negative net impact on jobs of the investment in water heaters (spending is

(a) Whether the jobs actually would be created depends on future labor market supply conditions and macroeconomic policy. See, for example, Solow (1994) or Moscovitch (1994). 


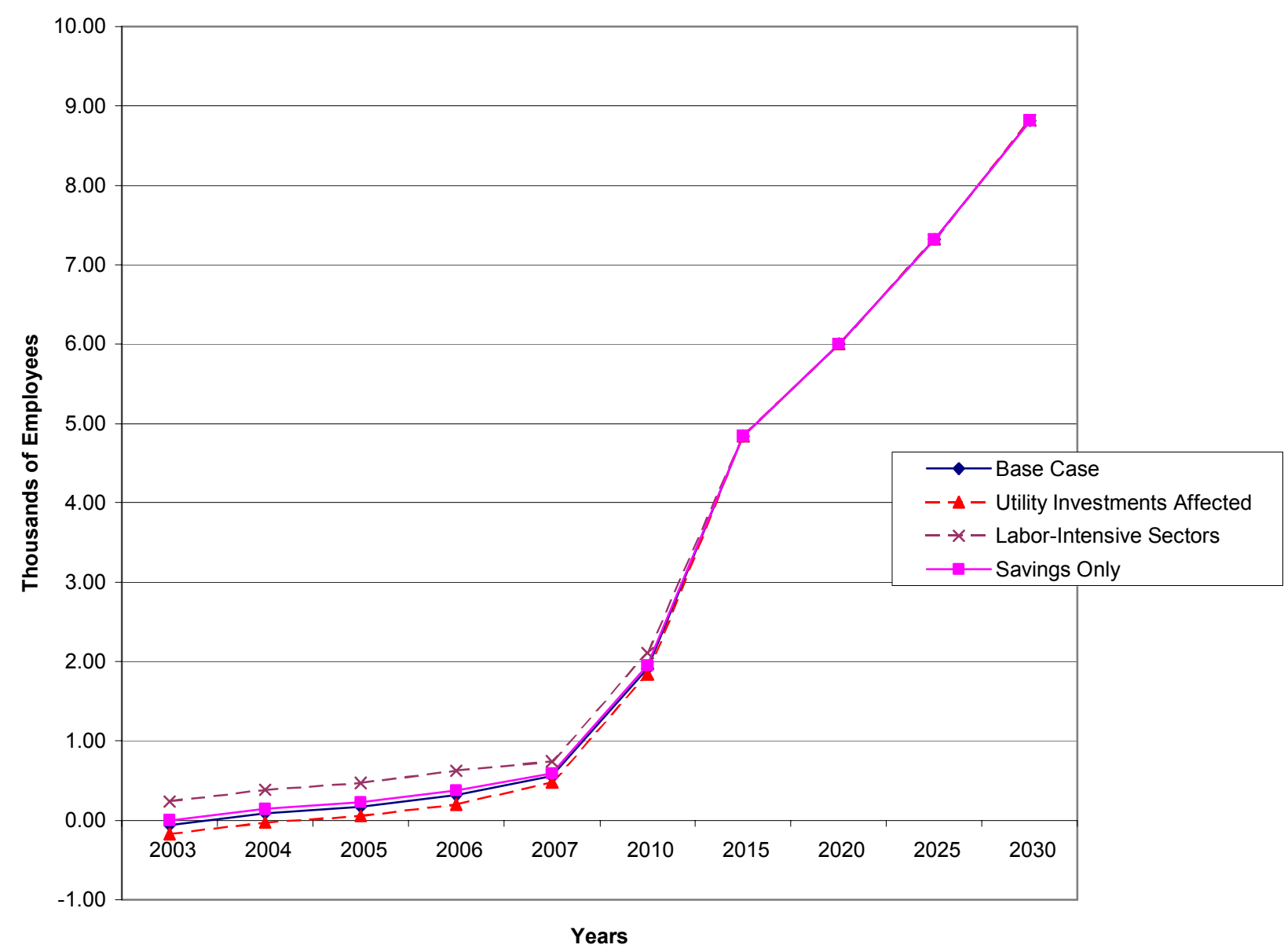

Figure 3.3. Employment Impacts of Investment in Heat Pump Water Heaters

transferred from labor-intensive to capital-intensive sectors). Thus, the Base Case lies slightly below the Savings-Only Case. Next, we consider the effect of energy conservation on investment in capital by electric utilities and gas utilities. If energy consumption decreases, it may be possible for utilities to defer investments they otherwise would make in plant and equipment.

To analyze this question, we assume that each reduction of 1 trillion Btu of annual electrical energy demand saves $\$ 32.9$ million of electric utility investment (about $\$ 590$ per MW of capacity) and every trillion Btu of natural gas saved in annual demand saves $\$ 5.29$ million of gas utility investment. ${ }^{\text {(a) }}$ Reduced investment by utilities releases resources from the utility construction sector, which is relatively capital-intensive, to the economy as a whole, which is slightly less so. The net effect is small - an

(a) For this report, we estimated electric power plant construction savings at about $\$ 590 / \mathrm{kW}$ of delivered electric energy, based on data in EIA (1997). The equivalent value for natural gas, is about $\$ 1.20 /$ cubic foot/day capacity, based on EIA (1996). 
increase of just 1000 jobs (the net employment impact is about 9800 instead of 8800). Thus, saved utility investment, to the extent it occurs, has a slightly positive impact on employment. ${ }^{(a)}$

So far, this analysis has assumed that the cost premium for heat pump water heaters is entirely due to their manufacture. The case in Figure 3.3 marked Labor-Intensive Sectors is a sensitivity case that shows if more labor-intensive appliance distribution sectors of the economy were affected by the initial investment (not just appliance manufacturing), the net employment effects of the investment premium would be higher, and the overall net effects could be above those of the energy savings alone. ${ }^{(b)}$ However, we have no reason to believe that traditional percentage wholesale and retail trade markups would necessarily be maintained in the face of the higher manufacturing cost. It is more likely that distribution, marketing, and installation costs would be about the same for the HPWH and the competitor unit.

Figure 3.4 shows that financing affects the size of the projected net employment effect. The net effect depends on the market penetration scenario itself (that is, how fast and at what cost the technologies enter the market) and on what activity in the U.S. economy is displaced by the investment in water heaters. Employment impacts are estimated for the Heat pump water heater market penetration of the GPRA Metrics scenarios under differing scenarios concerning the financing of substantial up-front investment. For example, in the base case, the funds necessary to finance the water heater investment are drawn proportionately from the all sectors of the economy. ${ }^{(\mathrm{c})}$ In the highest scenario in Figure 3.4 (Free Financing), the assumption is the investment does not impinge on U.S. economic activity, and thus, the entire incremental investment adds to U.S. final demand and domestic product. A number of reasons exist why this could happen. From a macroeconomic perspective, two plausible reasons are that consumers decide to spend previously accumulated savings or else the international financial markets judge the investment to be a cost-effective use of their loanable funds, so that investments in some other country are crowded out. This results in the maximum possible impact on U.S. employment from the investment, an impact large enough to dominate other macroeconomic effects of the technology.

(a) This analysis assumes that saved utility investment funds would be recycled in the economy, as are ordinary earnings. If these funds were used to make foreign investments, for example, the negative impact would be much greater.

(b) The differential employment impact of the HPWH investment arises because the appliance manufacturing sector and its suppliers are slightly more capital-intensive as a group than the economy as a whole. Thus, diverting investment funds from the rest of the economy to appliance manufacturing tends to reduce employment. If the investment cost premium were spread among more labor-intensive sectors, such as wholesale and retail trade, the average employment intensity of the HPWH investment would be much closer to the national average. For the sensitivity case in the figure, we assumed that manufacturing took $46 \%$ of the investment premium; wholesale and retail trade, $37 \%$; and construction, $17 \%$. These proportions are normal industry averages.

(c) Personal (household) consumption is assumed to represent $70 \%$ of spending; gross private fixed investment, $10 \%$; federal defense spending, $2 \%$; federal non-defense spending, $6 \%$; and state and local government spending, about $12 \%$. These percentages are close to the actual distribution of final demand among these sectors. 


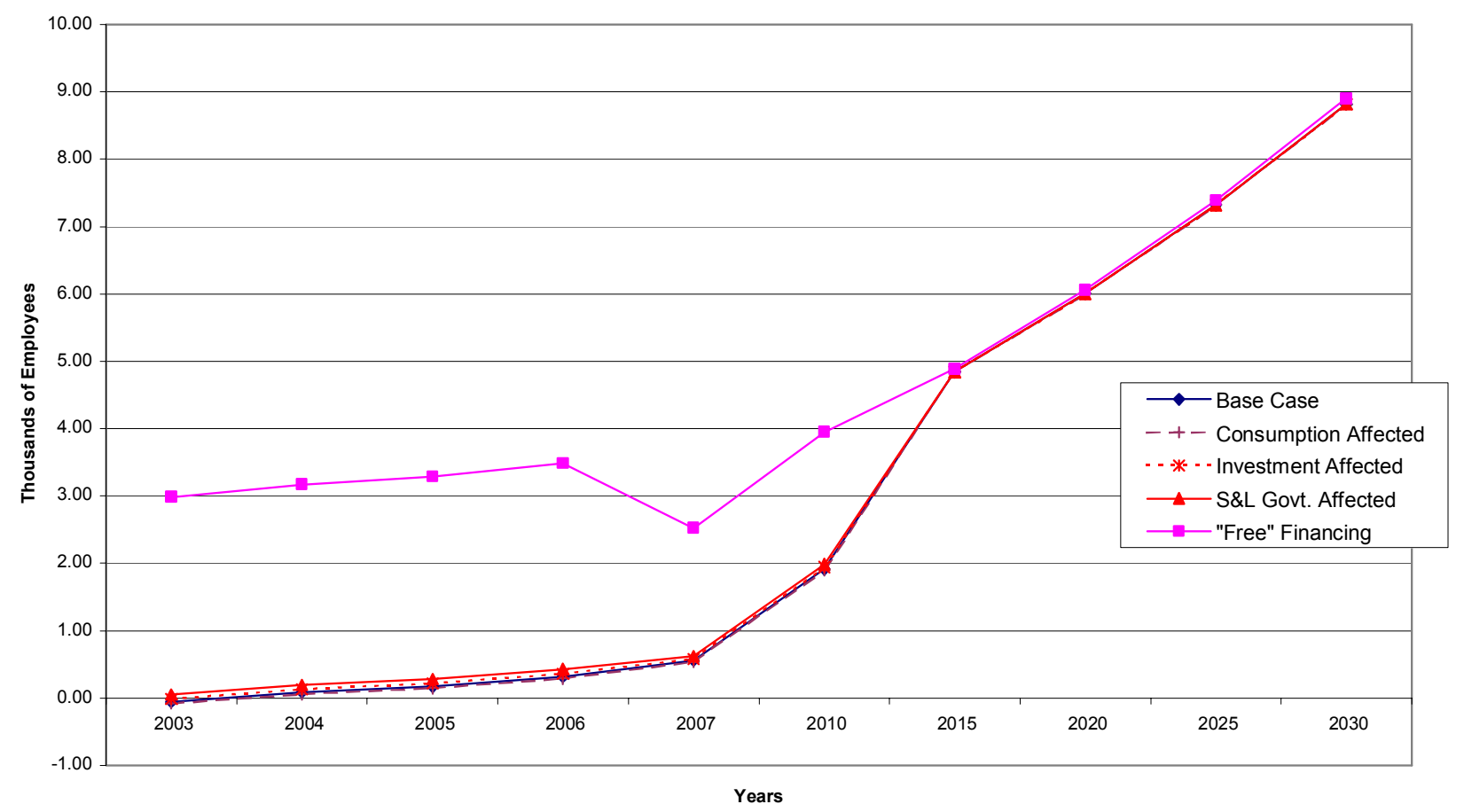

Figure 3.4. Effect of HPWH Financing on Employment

The other scenarios in Figure 3.4 demonstrate to slight-but-varying degrees that the employment impact would be temporary, if the new incremental investment in water heaters displaces enough other consumer spending or business investment. ${ }^{(a)}$ However, because the effects of energy savings are relatively large, the net effect on employment is positive. A major reason for the slight negative investment impact is, although the HPWH technology is cost-effective, it is slightly less employmentintensive than the general economy. ${ }^{(\mathrm{b})}$

Because the amount of the funds needed for investment in heat pump water heaters is the same in each scenario in Figure 3.4, the level of the offsetting impact depends on the relative employment intensity of economic activity in the various sectors from which the investment funds come. Overall, although government activity is particularly labor intensive, the differences in employment that would occur if domestic spending were reduced in different ways to make the HPWH investments are very small.

(a) The financing effects could be thought of in the following ways. If consumer spending is the only sector affected, it might be because consumers reduce their purchases of consumer durables like washing machines (or buy less expensive ones) to afford the additional water heater investments. Business investments could be reduced instead because lenders provide loans to households to pay water heaters instead of loans to business to buy plant and equipment. Finally, state and local government spending could be reduced because tax credits are allowed on state and local income taxes for investments of this type.

(b) Although a HPWH investment may be cost-effective in comparison with the alternative energy technology, these impact calculations do not address whether the HPWH investment provides as many net economic benefits to the economy as other, non-energy investments with which it also competes. 
Of course, jobs are not the only metric by which we can measure the macroeconomic impact of energy efficiency programs. Because different industries pay different wages on average, it is theoretically possible to create a number of low-paying jobs while reducing the number of well-paying jobs and overall income. Thus, it is worth looking at the impact on earnings as well as employment. Figure 3.5 illustrates the effects on national earned income of the various scenarios, previously shown in Figure 3.4, with their different sources of investment capital.

Figure 3.5 illustrates that, as before with employment, the impact of the water heater investments and savings on the national economic activity are positive when the investment does not crowd out domestic spending and investment. With the source of investment funds being the entire economy (Base Case), the net impact on national incomes is positive, as also was shown in Figure 3.4 for employment. As was true with employment, the impact on wage income is generally reduced (but not negative) if normal domestic investments are foreclosed by water heater investments. The difference if government investment is crowded out is near zero in the short run.

Figure 3.6 is the wage income equivalent of Figure 3.3, but does not show the same results. Because the initial investment has a larger gross product multiplier than the economy as a whole and occurs in a high-wage, capital-intensive sector, activity created in water heater manufacturing and its supplying

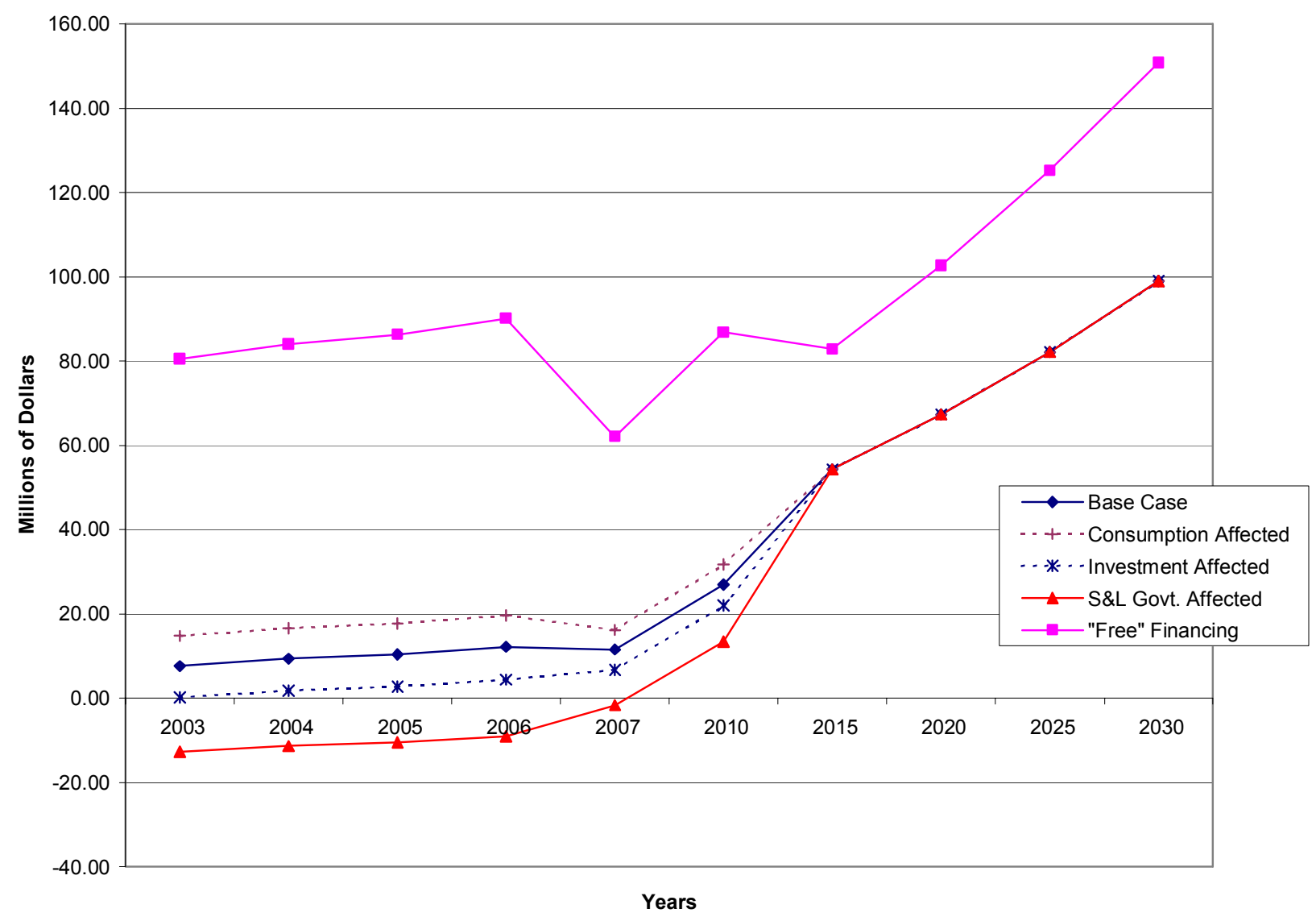

Figure 3.5. Impact of HPWH Investment on National Wage Income 


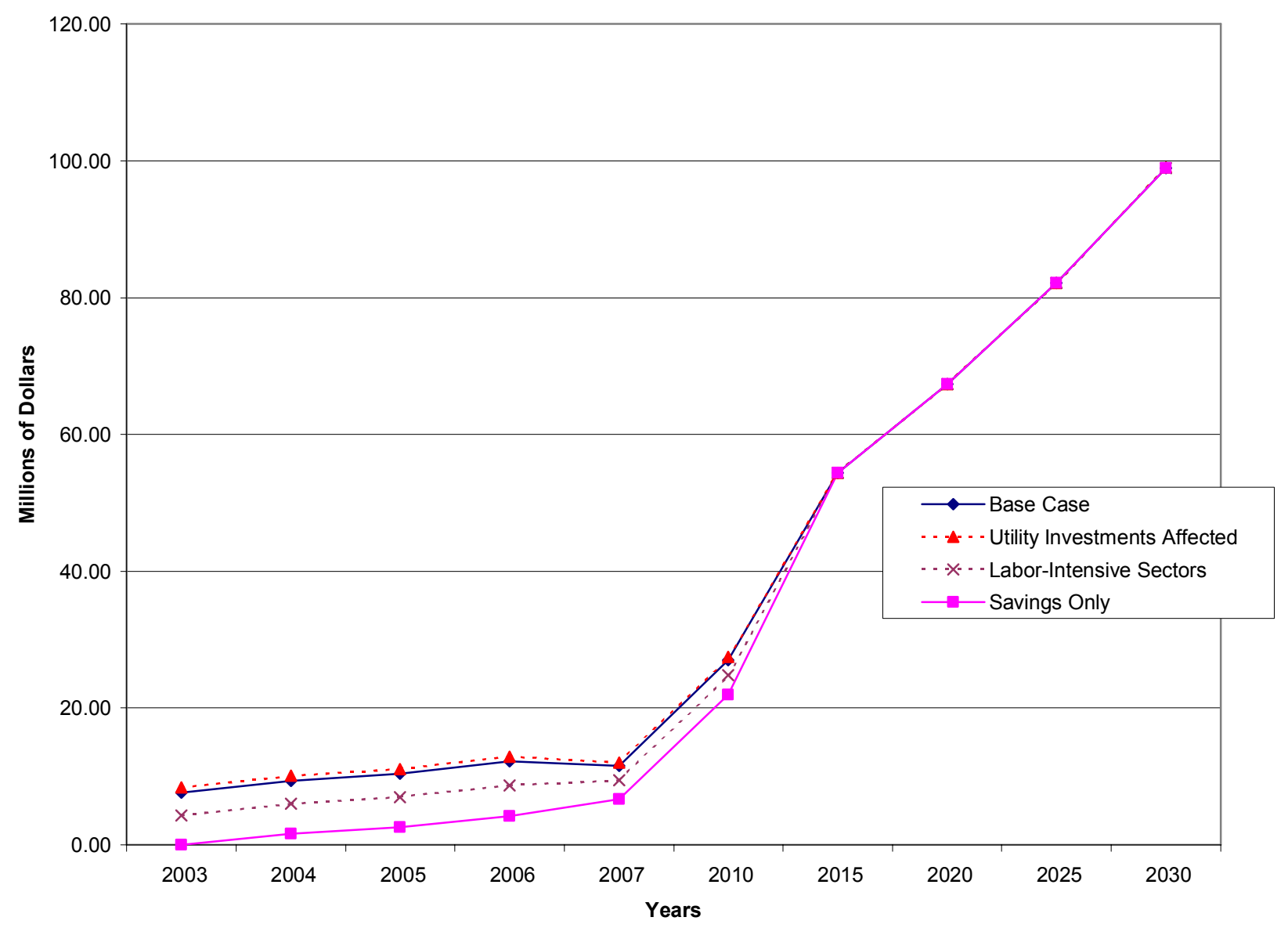

Figure 3.6. Sensitivity of Impacts on National Wage Income to HPWH Investments

industries employs fewer workers per dollar of activity than the national average but generates more-thanaverage income. Energy savings, if they are large enough, could reduce utility investment in new plant and equipment (mostly construction). Should this occur, Figure 3.6 shows that reducing construction activity frees up dollars that tend to have a slightly more positive impact on national wage income when spent on personal consumption, business investment, and government programs than if they had been spent in construction. ${ }^{(a)}$ Thus, the net impact on national wage income is very slight increase relative to the base case.

(a) In the case analyzed, this sign is the opposite of the comparable employment effect and is the combined result of inter-sector purchases and the wage rates in the affected sectors. The net effect is small, however, and could be of either sign, depending on exactly which sectors are affected. When relatively capital-intensive sectors spend the released investment funds, the effect is negative for both employment and income; when labor intensive sectors spend the money, the net effect is positive for both. The illustrated case involves a mix of sectors. 
Finally, the figure shows that if the investment in water heaters were distributed across more laborintensive industries rather than just appliance manufacturing, then there is a the net drag on national wage income, because the altered investment pattern would then represent a diversion of investment dollars into low-wage labor-intensive retail and wholesale distribution as well as high-wage construction and capitalintensive manufacturing. ${ }^{\text {(a) }}$ As before, however, it is likely that most of the premium in cost would be the additional cost of manufacturing.

\subsection{EPACT (Commercial Air Conditioning) Efficiency Standards}

Unlike heat pump water heaters, high-efficiency air conditioners (HEACs) installed in commercial buildings are not expected to require an incremental investment. Current assumptions for the EPACT program are that no additional cost will be required for the advanced equipment. Thus, the national economy is not stimulated by additional final demand focused on the manufacturing sectors that make commercial air conditioning equipment. Also, the national macroeconomic impacts are not sensitive to the financing of the investment premium because no premium is assumed.

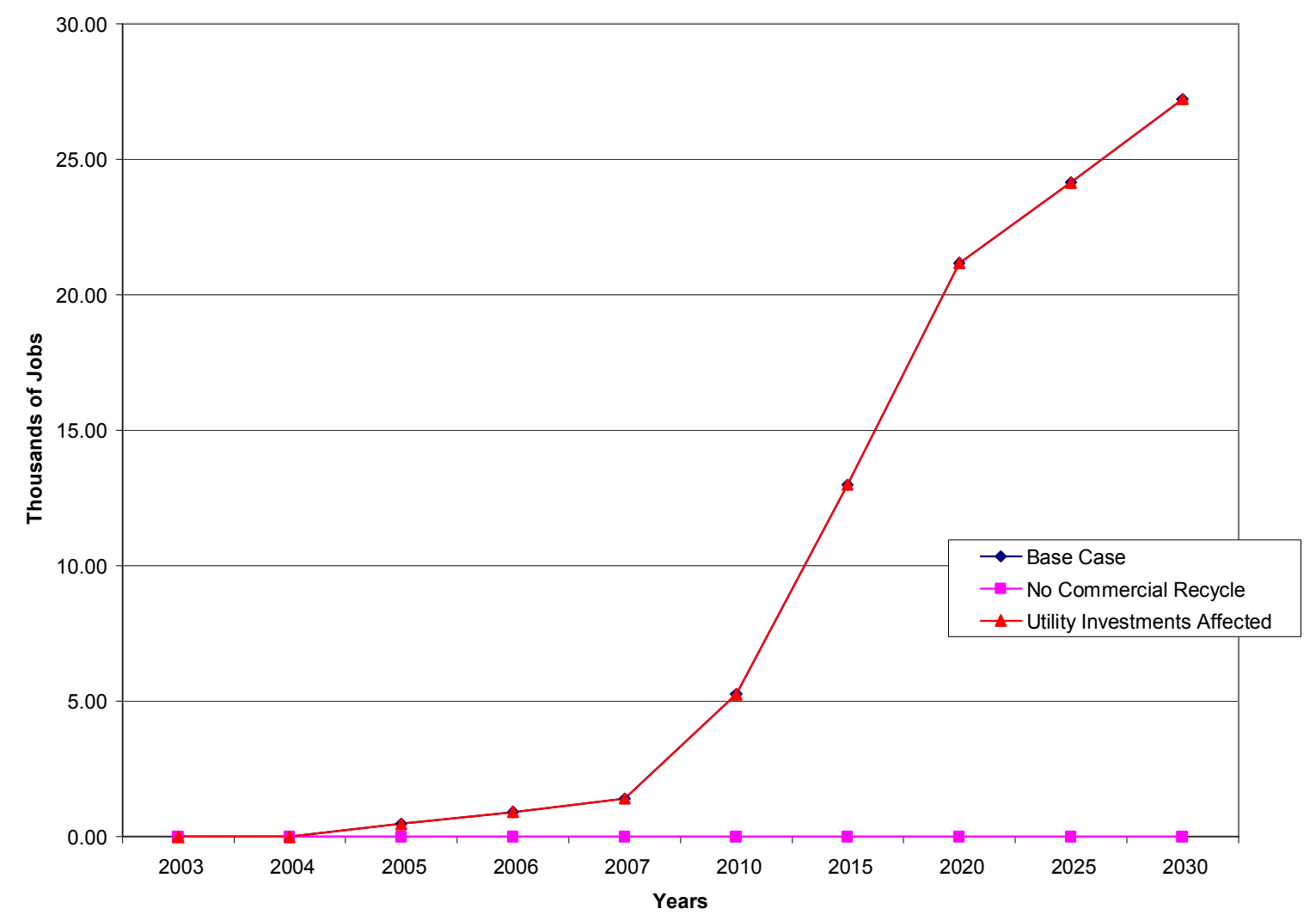

Figure note: Base Case and Utility Investment Cases are nearly identical

Figure 3.7. Impact on National Employment of EPACT Standards

(a) In this case, the investment premium was distributed $46 \%$ to appliance manufacturing, $37 \%$ to the wholesale and retail trade, and $17 \%$ to the construction sector for installation. 
The HPWH and HEAC scenarios also differ because the target market for HEAC is in commercial buildings. From a macroeconomic point of view, this difference is important because the destination for the energy/non-energy operational savings is not obvious. Potentially, energy savings would increase the profitability of firms that installed HEAC; however, the additional value-added per dollar of output could well be shared with the work force (in the form of higher wages due to higher productivity and effective bargaining by labor) and with the government (in the form of additional tax collections). With respect to business profits, it is not clear how much would be spent or invested, how much saved, and so on. However, even if a particular business had no immediate investment plans for the funds provided by energy savings, the economy as a whole would have abundant investment options available and the capital markets could readily absorb any savings. Therefore, we assume that energy savings by business (proportionately allocated to labor earnings, business profits, and taxes) are immediately recycled in the economy as consumer spending, business investment, and government spending. If the cost savings were not re-spent inside the U.S. economy (for example, they were invested in telecommunications in Asia), then that portion of the energy savings would have no positive effect on the economy as a whole. This is illustrated as the No Commercial Recycle case in the figure. As before, if the energy savings allow for the deferral of electric and gas utility infrastructure investments, there is a (very slight) positive impact on overall employment.

Figure 3.8 shows the net impact of the HEAC investments on the wage economy is significant and also positive (due strictly to energy savings).

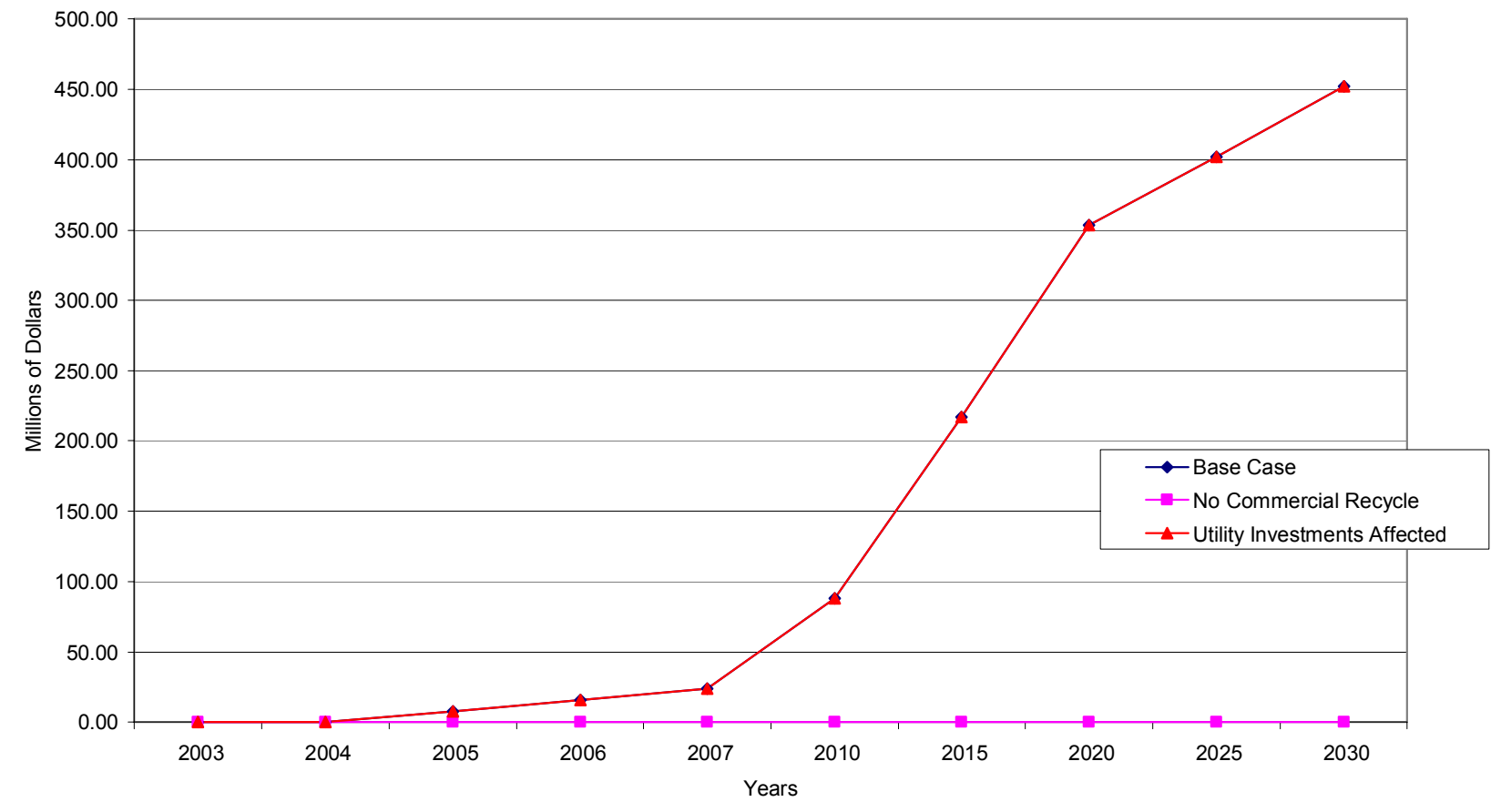

Figure 3.8. Impact of EPACT Standards Energy Savings on National Wage Income 


\subsection{Residential Building Integrated R\&D}

The final example program in this chapter is Residential Building Integrated $R \& D$, a program designed to reduce energy consumption in new residential buildings by implementation of better building designs and better buildings products and processes. According to the program objectives, and based on several results from prototypical homes, the new products, procedures, and designs eventually will cost about $2 \%$ more than their conventional competitors. The national economy is stimulated by additional final demand focused on the manufacturing sectors that make new products and equipment, and on sectors that implement the new processes. On the other hand, this additional investment requires capital that the nation's households and businesses otherwise would have had available to spend for other general investment and consumption purposes. Figure 3.9 illustrates this. The impacts of savings alone are slightly greater than the impact of the base case (which is virtually identical to the utility savings case in the figure), because the Base Case includes the net negative employment impact of diverting investment into equipment manufacture. Figure 3.9 also illustrates that, had the investment been made in laborintensive sectors, the impact of the investment on employment would have been still lower, mostly because the effects of concentrating investment in retail, wholesale, and construction produces relatively little GDP despite being labor intensive. As before, if utility capital investment can be saved because of reduced energy demand, the employment impacts are slightly larger.

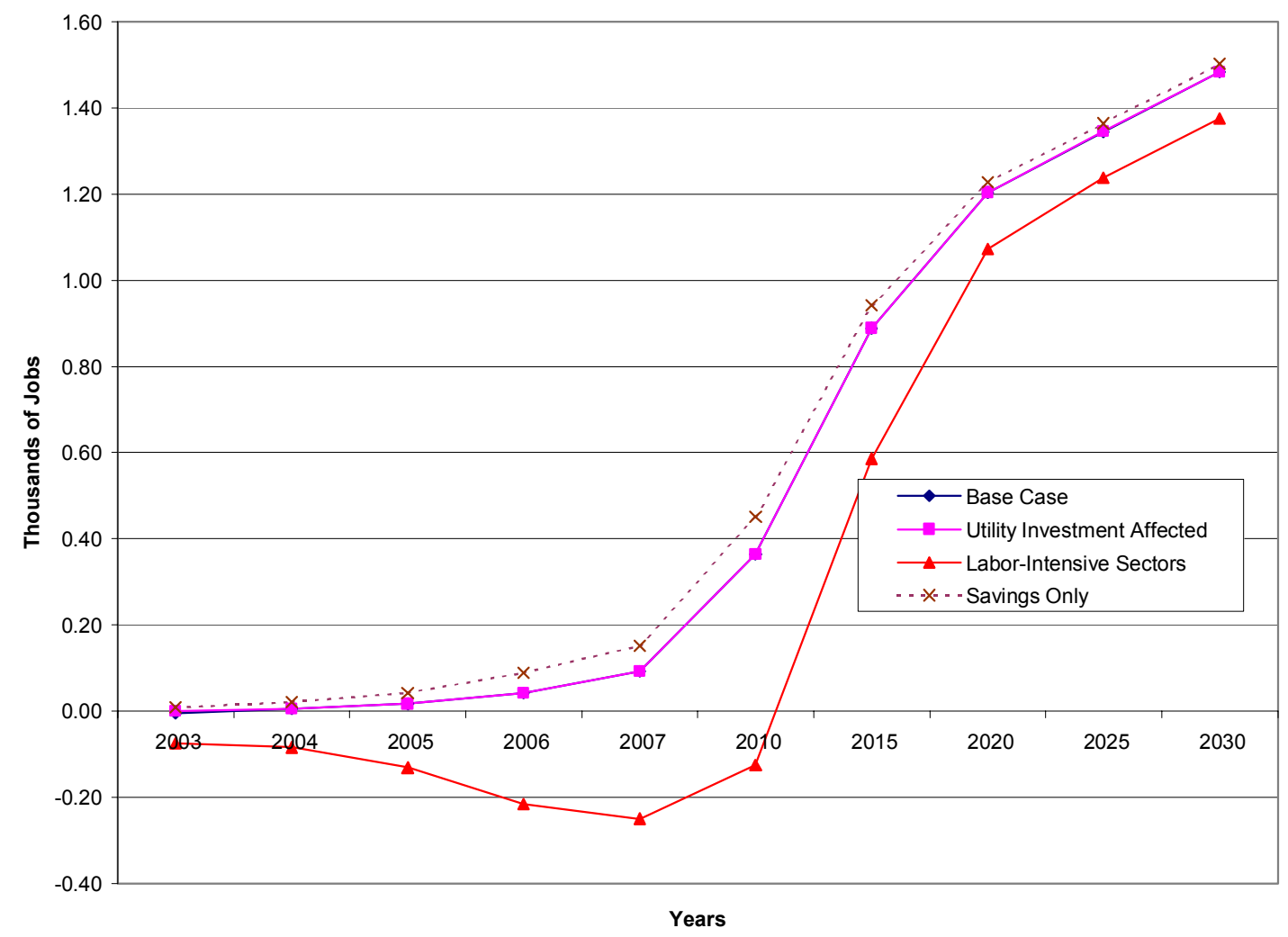

Figure note: Base Case and Utility Investment Cases are nearly identical

Figure 3.9. Impact of Building America Energy Savings on National Employment 
The earned income consequences of Residential Building Integrated R\&D arise from both the energy savings (which positively influence the economy as a whole) and the investment effects (which positively affect the high-wage manufacturing and construction sectors, but divert funds out of the relatively lowwage service sector). Thus, the Base Case lies above the Savings Only case. This impact is illustrated in Figure 3.10. The market penetration of energy-efficient homes creates additional jobs by moving activity out of the capital-intensive utility sector into manufacturing sectors that are generally more laborintensive and high-wage. If the investment related to Integrated R\&D is spread across labor-intensive, low-output, sectors the impact on overall income is negative. These other sectors generally pay lower average wages, acting as a net drag on incomes. If the reduced energy demand also reduces utility capital expenditures, the income consequences are slightly positive, for the same reasons as were found with the HPWH technology.

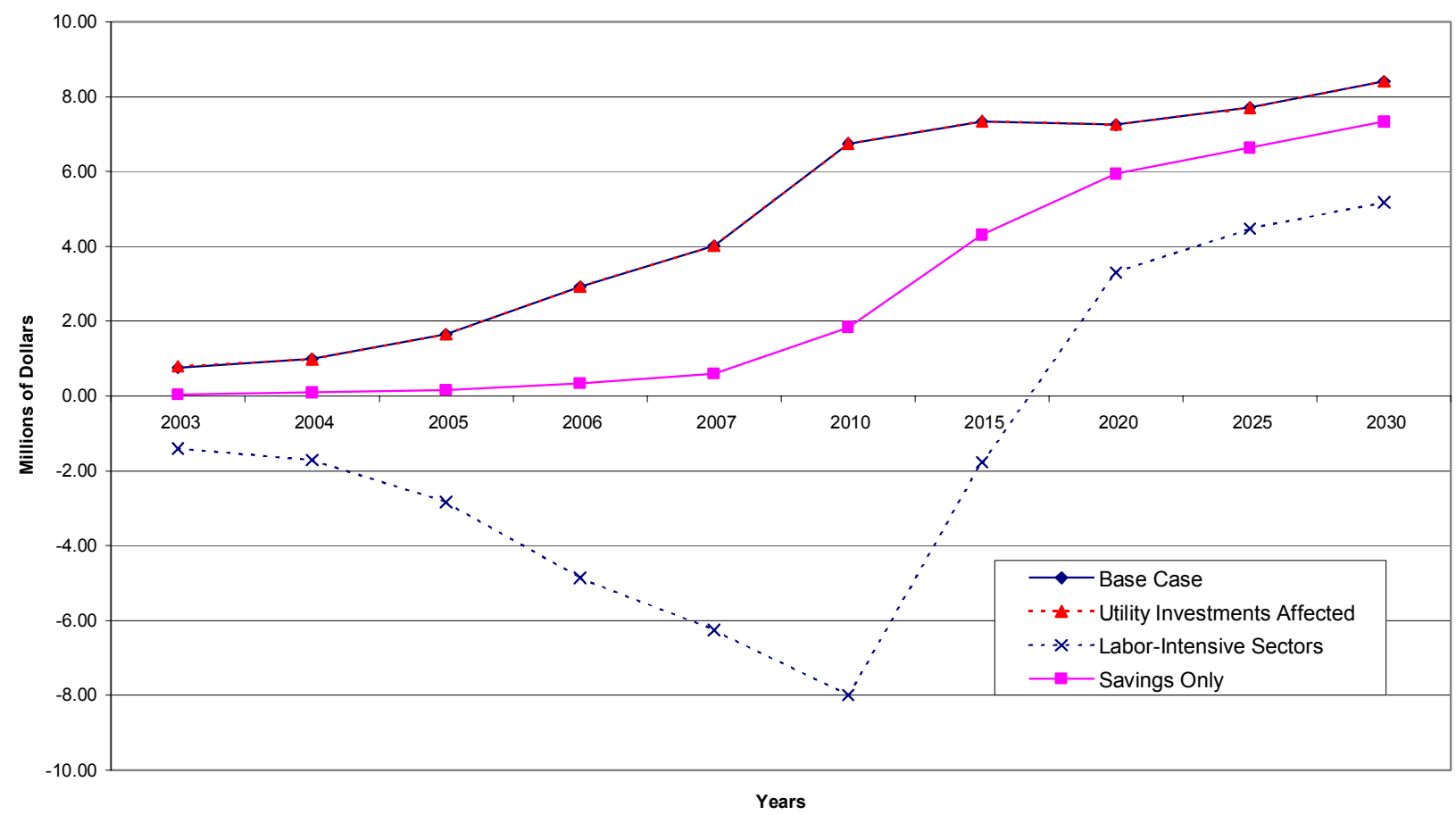

Figure note: Base Case and Utility Investment Cases are nearly identical

Figure 3.10. Impact of Building America Energy Savings on National Wage Income 


\subsection{Comparison with Other Studies}

The results in this study are somewhat different than other previously published work. This difference is largely due to a few critical assumptions where honest disagreement is possible. In order to highlight these differences and to improve reader understanding of how building technologies may affect the U.S. macro economy, this section looks closely at differences between the studies.

\subsection{Comparison to the 1992 ACEEE Study}

One of the studies that is frequently cited to demonstrate the employment impacts of investments in conservation technologies is Geller, De Cicco, and Laitner, Energy Efficiency and Job Creation: The Employment and Income Benefits from Investing in Energy Conserving Technologies, published by the American Council for an Energy-Efficient Economy (ACEEE) in 1992. That study used the IMPLAN model (Minnesota IMPLAN Group 1997) to derive employment and income multipliers for a number of sectors that were then used to estimate the impacts of energy conservation investments and savings. One of the reasons our results differ may stem from the use of different economic sectors, resulting in different multipliers. The ImBuild II model is designed specifically to analyze the results of building technologies and therefore has more detail in those manufacturing and trade sectors closely aligned with residential and commercial building equipment and operations, while summarizing those sectors of less direct importance. The ACEEE analysis was intended to be more general-purpose, including a wider variety of manufacturing sectors. Table 4.1 compares the Geller et al. (1992) gross output and employment multipliers with the most closely related gross output and employment multipliers in the ImBuild II model. ${ }^{(a)}$

Because the ImBuild II model and ACEEE (Geller et al. 1992) analysis have some different sectors, some differences in impacts are present due to these differences. ${ }^{(b)}$ More important, however, the Geller et al. (1992) analysis made different assumptions than we have concerning the economic treatment of new energy-efficient technologies, particularly the source of funds for investment. In their example of a new, more efficient electric motor, Geller et al. (1992) treat this investment in the pulp and paper industry as if it were a reduction in sales to consumers from that sector; in other words, a reduction in demand, not a change in supply technology. In the corrected treatment (the example that follows in Table 4.2), we recalculate the Geller et al. (1992) impact of an energy efficient investment in an electric motor. Note that in our re-analysis, the multiplier for the pulp and paper industry is not a factor because demand for pulp and paper is not directly affected by the energy efficient investment. ${ }^{(c)}$

(a) Gross output is the total value of economic activity in the economy, unadjusted for costs of production. It sums the value of final output and the value of intermediate goods and services. The latter are a cost of business in producing the former. While gross output is useful as a basis for calculating employment and income effects, it is not an accurate measure of net creation of wealth.

(b) It should also be pointed out that the ACEEE model is based on the 1987 benchmark input-output matrix for the US, while IMBuild II is based on the 1992 benchmark matrix. These structural differences can be significant depending on specific detailed sectors of interest. Some portion of the difference of the ACEEE numbers is due to the structural change represented in the 1992 benchmark matrix.

(c) A very small indirect effect would be related to the change in the overall size of the economy. 
Table 4.1. Comparison of Output and Employment Multipliers for the ACEEE Version of IMPLAN and ImBuild II Model

\begin{tabular}{|c|c|c|c|c|}
\hline \multirow[b]{2}{*}{ Industry } & \multicolumn{2}{|c|}{ Output (Total \$ Output per \$ Final Demand) } & \multicolumn{2}{|c|}{ Jobs (Total per Million \$ Final Demand) } \\
\hline & ACEEE & ImBuild II & ACEEE & ImBuild II \\
\hline Agriculture & 2.1198 & 2.2485 & 26.86 & 26.55 \\
\hline Other Mining & 1.8170 & $\begin{array}{l}\text { Mining exc. Nonmetallic minerals } \\
=1.9149\end{array}$ & 13.51 & $\begin{array}{l}\text { Mining exc. Nonmetallic } \\
\text { minerals }=10.31\end{array}$ \\
\hline Coal Mining & 1.8690 & 1.9149 & 12.88 & 10.31 \\
\hline $\begin{array}{l}\text { Oil and Gas } \\
\text { Extraction }\end{array}$ & 1.3438 & 1.9149 & 7.02 & 10.31 \\
\hline $\begin{array}{l}\text { Stone and Clay } \\
\text { Mining }\end{array}$ & $\begin{array}{l}\text { Use } \\
\text { "Other } \\
\text { Mining" }\end{array}$ & $\begin{array}{l}\text { Nonmetallic Mineral Mining= } \\
1.8029\end{array}$ & $\begin{array}{l}\text { Use } \\
\text { "Other } \\
\text { Mining" }\end{array}$ & $\begin{array}{l}\text { Nonmetallic Mineral } \\
\text { Mining=16.82 }\end{array}$ \\
\hline Construction & 1.9228 & $\begin{array}{l}\text { Res. }=2.1370 \\
\text { Comm. }=2.0223 \\
\text { Other }=1.9880\end{array}$ & 20.97 & $\begin{array}{l}\text { Res. }=20.26 \\
\text { Comm. }=21.26 \\
\text { Other }=15.73\end{array}$ \\
\hline Wood Products & $\begin{array}{l}\text { Use } \\
\text { "Other } \\
\text { Mfg." }\end{array}$ & $\begin{array}{l}\text { Other wood Prod. }=2.3549 \\
\text { Millwork }=2.3753 \\
\text { Fabricated Bldgs }=2.4105 \\
\text { Furniture and Fixtures }=2.1412\end{array}$ & $\begin{array}{l}\text { Use } \\
\text { "Other } \\
\text { Mfg." }\end{array}$ & $\begin{array}{l}\text { Other wood Prod. }=22.00 \\
\text { Millwork }=24.79 \\
\text { Fabricated Bldgs }=22.42 \\
\text { Furniture and Fixtures }=22.82\end{array}$ \\
\hline Paper & 2.1011 & $\begin{array}{l}\text { Paper Prod. Exc. Containers }= \\
2.2548 \\
\text { Containers and Boxes }=2.4290 \\
\text { Newspapers and Printing }=1.8713\end{array}$ & 14.29 & $\begin{array}{l}\text { Paper Prod. Exc. Containers }= \\
15.61 \\
\text { Containers and Boxes }=18.10 \\
\text { Newspapers and Printing }=24.16\end{array}$ \\
\hline Stone, Glass, Clay & 1.9051 & $\begin{array}{l}\text { See Stone \& Clay, or Glass \& } \\
\text { Glass Products }\end{array}$ & 17.25 & $\begin{array}{l}\text { See Stone \& Clay, or Glass \& } \\
\text { Glass Products }\end{array}$ \\
\hline $\begin{array}{l}\text { Glass \& Glass } \\
\text { Products }\end{array}$ & $\begin{array}{l}\text { Use } \\
\text { "Stone, } \\
\text { Clay \& } \\
\text { Glass" }\end{array}$ & $\begin{array}{l}\text { Other Glass Prod. }=1.9202 \\
\text { Glass Containers }= \\
1.9714\end{array}$ & $\begin{array}{l}\text { Use } \\
\text { "Stone, } \\
\text { Clay \& } \\
\text { Glass" }\end{array}$ & $\begin{array}{l}\text { Other Glass Prod. }=17.39 \\
\text { Glass Containers }=15.74\end{array}$ \\
\hline $\begin{array}{l}\text { Stone and Clay } \\
\text { Products }\end{array}$ & $\begin{array}{l}\text { Use } \\
\text { "Stone, } \\
\text { Clay \& } \\
\text { Glass" }\end{array}$ & $\begin{array}{l}\text { Cement }=2.0988 \\
\text { Lime and Gypsum }=2.3267 \\
\text { Mineral Wool }=1.9620 \\
\text { Other Nonmetallic Minerals = } \\
2.0555\end{array}$ & $\begin{array}{l}\text { Use } \\
\text { "Stone, } \\
\text { Clay \& } \\
\text { Glass" }\end{array}$ & $\begin{array}{l}\text { Cement }=13.64 \\
\text { Lime and Gypsum }=33.32 \\
\text { Mineral Wool }=15.27 \\
\text { Other Nonmetallic Minerals = } \\
17.58\end{array}$ \\
\hline
\end{tabular}


Table 4.1. (contd)

\begin{tabular}{|c|c|c|c|c|}
\hline \multirow[b]{2}{*}{ Industry } & \multicolumn{2}{|c|}{ Output (Total \$ Output per \$ Final Demand) } & \multicolumn{2}{|c|}{ Jobs (Total per Million \$ Final Demand) } \\
\hline & ACEEE & ImBuild II & ACEEE & ImBuild II \\
\hline Metal Durables & 1.9390 & $\begin{array}{l}\text { Metal Containers }=2.8851 \\
\text { Structural Metal }=2.2236 \\
\text { Metal Doors, etc. }=2.2916 \\
\text { Sheet Metal Work }=2.2086 \\
\text { Other Structural Metal Products } \\
=2.2401 \\
\text { Screw Machine Products }=2.1828 \\
\text { Other Fabricated Metal Products } \\
=2.1079\end{array}$ & 17.28 & $\begin{array}{l}\text { Metal Containers }=17.21 \\
\text { Structural Metal }=22.29 \\
\text { Metal Doors, etc. }=21.29 \\
\text { Sheet Metal Work }=18.47 \\
\text { Other Structural Metal Products } \\
=24.76 \\
\text { Screw Machine Products }=13.08 \\
\text { Other Fabricated Metal Products } \\
=19.86\end{array}$ \\
\hline Food & 2.4489 & Food and Tobacco $=2.4342$ & 19.77 & Food and Tobacco $=18.16$ \\
\hline $\begin{array}{l}\text { General Industrial } \\
\text { Machines }\end{array}$ & $\begin{array}{l}\text { Use } \\
\text { "Other } \\
\text { Mfg." }\end{array}$ & $\begin{array}{l}\text { Engines and Turbines }=2.2750 \\
\text { Machinery and Equip. }=2.0332\end{array}$ & $\begin{array}{l}\text { Use } \\
\text { "Other } \\
\text { Mfg." }\end{array}$ & $\begin{array}{l}\text { Engines and Turbines }=15.85 \\
\text { Machinery and Equip. }=16.37\end{array}$ \\
\hline $\begin{array}{l}\text { Office \& } \\
\text { Computing Equip. }\end{array}$ & $\begin{array}{l}\text { Use } \\
\text { "Other } \\
\text { Mfg." }\end{array}$ & $\begin{array}{l}\text { Computer and Office Equip. }= \\
2.2966\end{array}$ & $\begin{array}{l}\text { Use } \\
\text { "Other } \\
\text { Mfg." }\end{array}$ & 18.40 \\
\hline $\begin{array}{l}\text { Service Industry } \\
\text { Machines }\end{array}$ & $\begin{array}{l}\text { Use } \\
\text { "Other } \\
\text { Mfg." }\end{array}$ & $\begin{array}{l}\text { Comm. Laundry Equip. }=2.1471 \\
\text { Comm. Refrig. and Heating Equip. } \\
=2.2693 \\
\text { Other Service Equip. }=2.0799 \\
\text { Power Equip. }=2.1467\end{array}$ & $\begin{array}{l}\text { Use } \\
\text { "Other } \\
\text { Mfg." }\end{array}$ & $\begin{array}{l}\text { Comm. Laundry Equip. }=17.04 \\
\text { Comm. Refrig. and Heating } \\
\text { Equip. }=18.26 \\
\text { Other Service Equip. }=16.86 \\
\text { Power Equip. }=20.55\end{array}$ \\
\hline $\begin{array}{l}\text { Electric Industrial } \\
\text { Equip. }\end{array}$ & $\begin{array}{l}\text { Use } \\
\text { "Other } \\
\text { Mfg." }\end{array}$ & $\begin{array}{l}\text { Motors and Generators }=2.1398 \\
\text { Relays and Industr. Controls }= \\
1.9052 \\
\text { Other Electrical Equip. }=1.9870\end{array}$ & $\begin{array}{l}\text { Use } \\
\text { "Other } \\
\text { Mfg." }\end{array}$ & $\begin{array}{l}\text { Motors and Generators }=18.37 \\
\text { Relays and Industr. Controls }= \\
17.15 \\
\text { Other Electrical Equip. }=16.24\end{array}$ \\
\hline $\begin{array}{l}\text { Household } \\
\text { Appliances }\end{array}$ & $\begin{array}{l}\text { Use } \\
\text { "Other } \\
\text { Mfg." }\end{array}$ & $\begin{array}{l}\text { Heating Equip. }=2.0574 \\
\text { Household Cooking }=2.4073 \\
\text { HH Refrig. and Freezers }=2.3763 \\
\text { HH Laundry }=2.3336 \\
\text { Electric Houseware } \& \text { Fans }= \\
2.2172 \\
\text { HH Vacuum Cleaners }=2.1232 \\
\text { HH Appliances n.e.c. }=2.4111\end{array}$ & $\begin{array}{l}\text { Use } \\
\text { "Other } \\
\text { Mfg." }\end{array}$ & $\begin{array}{l}\text { Heating Equip. }=17.75 \\
\text { Household Cooking }=18.87 \\
\text { HH Refrig. and Freezers }=18.49 \\
\text { HH Laundry }=17.55 \\
\text { Electric Houseware \& Fans }= \\
20.70 \\
\text { HH Vacuum Cleaners }=14.54 \\
\text { HH Appliances n.e.c. }=19.08\end{array}$ \\
\hline $\begin{array}{l}\text { Electric Lighting } \\
\text { \& Wiring }\end{array}$ & $\begin{array}{l}\text { Use } \\
\text { "Other } \\
\text { Mfg." }\end{array}$ & $\begin{array}{l}\text { Lighting Bulbs, Tubing }=1.8387 \\
\text { Other Lighting and Wiring }= \\
2.0891\end{array}$ & $\begin{array}{l}\text { Use } \\
\text { "Other } \\
\text { Mfg." }\end{array}$ & $\begin{array}{l}\text { Lighting Bulbs, Tubing }=18.35 \\
\text { Other Lighting and Wiring }= \\
18.59\end{array}$ \\
\hline
\end{tabular}


Table 4.1. (contd)

\begin{tabular}{|c|c|c|c|c|}
\hline \multirow[b]{2}{*}{ Industry } & \multicolumn{2}{|c|}{ Output (Total \$ Output per \$ Final Demand) } & \multicolumn{2}{|c|}{ Jobs (Total per Million \$ Final Demand) } \\
\hline & ACEEE & ImBuild II & ACEEE & ImBuild II \\
\hline $\begin{array}{l}\text { Electronic } \\
\text { Components \& } \\
\text { Access. }\end{array}$ & $\begin{array}{l}\text { Use } \\
\text { "Other } \\
\text { Mfg." }\end{array}$ & $\begin{array}{l}\text { Communications Equip }=2.0176 \\
\text { Electronic Components }=2.0177 \\
\text { Misc. Electr. Supplies }=2.1555 \\
\text { Measuring and Control Devices }= \\
1.8691\end{array}$ & $\begin{array}{l}\text { Use } \\
\text { "Other } \\
\text { Mfg." }\end{array}$ & $\begin{array}{l}\text { Communications Equip }=14.07 \\
\text { Electronic Components }=16.50 \\
\text { Misc. Electr. Supplies }=17.61 \\
\text { Measuring and Control Devices } \\
=18.49\end{array}$ \\
\hline Other Mfg. & 2.0310 & $\begin{array}{l}\text { Fabrics and Yarn=2.4393 } \\
\text { Other Textiles }=2.4835 \\
\text { Apparel }=2.4761 \\
\text { Fabricated Textile } \\
\text { Products }=2.3786 \\
\text { Rubber and Plastic Products } \\
=2.2040 \\
\text { Footware and Leather }=2.3734 \\
\text { Other Manufacturing }=1.8997\end{array}$ & 20.75 & $\begin{array}{l}\text { Fabrics and Yarn=29.98 } \\
\text { Other Textiles=20.44 } \\
\text { Apparel }=29.20 \\
\text { Fabricated Textile } \\
\text { Products }=25.71 \\
\text { Rubber and Plastic Products } \\
=17.83 \\
\text { Footware and Leather }=26.17 \\
\text { Other Manufacturing }=16.43\end{array}$ \\
\hline Chemicals & 2.1282 & $\begin{array}{l}\text { Indust. } \text { Chemicals }=2.3165 \\
\text { Agr. Chemicals }=2.2837 \\
\text { Plastics }=2.4810 \\
\text { Synthetic Materials }=2.3576 \\
\text { Drugs and Cleaning }=1.9355 \\
\text { Paints and Allied }=2.2987\end{array}$ & 13.06 & $\begin{array}{l}\text { Indust. } \text { Chemicals }=13.31 \\
\text { Agr. } \text { Chemicals }=14.29 \\
\text { Plastics }=16.28 \\
\text { Synthetic Materials }=17.72 \\
\text { Drugs and Cleaning }=12.42 \\
\text { Paints and Allied }=13.73\end{array}$ \\
\hline Refining & 2.0209 & $\begin{array}{l}\text { Petroleum Ref. }=2.6651 \\
\text { Other Petrol. Products }=2.5353\end{array}$ & 7.14 & $\begin{array}{l}\text { Petroleum Ref. }=11.81 \\
\text { Other Petrol. Products }=13.00\end{array}$ \\
\hline Primary Metals & 2.0150 & $\begin{array}{l}\text { Iron and Steel }=2.2818 \\
\text { Aluminum }=2.6040 \\
\text { Other Nonferrous }=2.6021\end{array}$ & 13.05 & $\begin{array}{l}\text { Iron and Steel }=16.35 \\
\text { Aluminum }=15.19 \\
\text { Other Nonferrous }=21.12\end{array}$ \\
\hline Motor Vehicles & 2.1871 & $\begin{array}{l}\text { Motor Vehicles } \\
=2.4137 \\
\text { Bodies, Trailers, Parts }=2.7307 \\
\text { Aircraft and Parts }=2.1566 \\
\text { Other Transport Equip. }=2.0916\end{array}$ & 13.70 & $\begin{array}{l}\text { Motor Vehicles } \\
=16.12 \\
\text { Bodies, Trailers, Parts }=18.89 \\
\text { Aircraft and Parts }=17.69 \\
\text { Other Transport Equip. }=18.43\end{array}$ \\
\hline $\begin{array}{l}\text { Transport./Commu } \\
\text { nication }\end{array}$ & 1.5777 & $\begin{array}{l}\text { Rail Trans. }=1.8008 \\
\text { Motor Freight }=1.9660 \\
\text { Water Trans. }=1.9620 \\
\text { Air Trans. }=1.9213 \\
\text { Pipelines }=1.8427 \\
\text { Communications }=1.7330\end{array}$ & 16.37 & $\begin{array}{l}\text { Rail Trans. }=20.02 \\
\text { Motor Freight }=19.36 \\
\text { Water Trans. }=15.12 \\
\text { Air Trans. }=18.03 \\
\text { Pipelines }=16.39 \\
\text { Communications }=13.48\end{array}$ \\
\hline Electric Utilities & 1.7821 & 1.6978 & 9.54 & 9.15 \\
\hline Gas Utilities & 1.9921 & 2.6293 & 7.41 & 14.74 \\
\hline $\begin{array}{l}\text { Water/Sewer } \\
\text { Utilities }\end{array}$ & 1.5943 & 2.1390 & 14.00 & 25.93 \\
\hline
\end{tabular}


Table 4.1. ( contd0

\begin{tabular}{|c|c|c|c|c|}
\hline \multirow[b]{2}{*}{ Industry } & \multicolumn{2}{|c|}{ Output (Total \$ Output per \$ Final Demand) } & \multicolumn{2}{|c|}{ Jobs (Total per Million \$ Final Demand) } \\
\hline & ACEEE & ImBuild II & ACEEE & ImBuild II \\
\hline Retail Trade & 1.5984 & $\begin{array}{l}\text { Wholesale \& Retail Trade }= \\
1.5175\end{array}$ & 32.24 & $\begin{array}{l}\text { Wholesale \& Retail Trade }= \\
23.64\end{array}$ \\
\hline $\begin{array}{l}\text { Finance/Insurance/ } \\
\text { Real estate }\end{array}$ & 1.4220 & See Below & 10.10 & See Below \\
\hline $\begin{array}{l}\text { Finance and } \\
\text { Insurance }\end{array}$ & $\begin{array}{l}\text { Use } \\
\text { FIRE }\end{array}$ & 1.7593 & $\begin{array}{l}\text { Use } \\
\text { FIRE }\end{array}$ & 16.60 \\
\hline Real Estate & $\begin{array}{l}\text { Use } \\
\text { FIRE }\end{array}$ & $\begin{array}{l}\text { Owner Occ. } \text { Dwells. }=1.2343 \\
\text { Real Est and Royalties }=1.4514\end{array}$ & $\begin{array}{l}\text { Use } \\
\text { FIRE }\end{array}$ & $\begin{array}{l}\text { Owner Occ. } \text { Dwells. }=4.70 \\
\text { Real Est and Royalties }=7.63\end{array}$ \\
\hline $\begin{array}{l}\text { Hotels and } \\
\text { Lodging Places }\end{array}$ & 1.5815 & 1.7630 & 36.13 & 34.92 \\
\hline $\begin{array}{l}\text { Business \& Prof. } \\
\text { Services }\end{array}$ & $\begin{array}{l}\text { Use } \\
\text { "Other } \\
\text { Svc." }\end{array}$ & $\begin{array}{l}\text { Bus, Legal, Arch, Engin., Prof. , } \\
\text { "Other"= } 1.5667\end{array}$ & $\begin{array}{l}\text { Use } \\
\text { "Other } \\
\text { Svc." }\end{array}$ & $\begin{array}{l}\text { Bus, Legal, Arch, Engin., Prof., } \\
\text { "Other' = } 18.00\end{array}$ \\
\hline Other Services & 1.3726 & $\begin{array}{l}\text { Personal and Repair Services }= \\
1.7289\end{array}$ & 26.45 & $\begin{array}{l}\text { Personal and Repair Services }= \\
26.48\end{array}$ \\
\hline $\begin{array}{l}\text { Eating and } \\
\text { Drinking Places }\end{array}$ & $\begin{array}{l}\text { Use } \\
\text { "Other } \\
\text { Svc." }\end{array}$ & 2.0549 & $\begin{array}{l}\text { Use } \\
\text { "Other } \\
\text { Svc." }\end{array}$ & 33.85 \\
\hline $\begin{array}{l}\text { Auto Repair \& } \\
\text { Service }\end{array}$ & $\begin{array}{l}\text { Use } \\
\text { "Other } \\
\text { Svc." }\end{array}$ & 1.9315 & $\begin{array}{l}\text { Use } \\
\text { "Other } \\
\text { Svc." }\end{array}$ & 19.17 \\
\hline $\begin{array}{l}\text { Amusements \& } \\
\text { Recreation Service }\end{array}$ & $\begin{array}{l}\text { Use } \\
\text { "Other } \\
\text { Svc." }\end{array}$ & 1.7788 & $\begin{array}{l}\text { Use } \\
\text { "Other } \\
\text { Svc." }\end{array}$ & 23.45 \\
\hline Health Services & 1.9766 & 1.6006 & 23.15 & 21.59 \\
\hline $\begin{array}{l}\text { Education \& Other } \\
\text { Svcs. }\end{array}$ & $\begin{array}{l}\text { Use } \\
\text { "Other } \\
\text { Svc." }\end{array}$ & 1.7747 & $\begin{array}{l}\text { Use } \\
\text { "Other } \\
\text { Svc." }\end{array}$ & 35.10 \\
\hline Federal Enterprises & $\begin{array}{l}\text { Use } \\
\text { "Other } \\
\text { Svc." }\end{array}$ & 1.3370 & $\begin{array}{l}\text { Use } \\
\text { "Other } \\
\text { Svc." }\end{array}$ & 22.84 \\
\hline $\begin{array}{l}\text { State \& Local } \\
\text { Govt. Enterprises }\end{array}$ & $\begin{array}{l}\text { Use } \\
\text { "Other } \\
\text { Svc." }\end{array}$ & $\begin{array}{l}\text { S\& L Enterprises } \\
=2.2502\end{array}$ & $\begin{array}{l}\text { Use } \\
\text { "Other } \\
\text { Svc." }\end{array}$ & 41.48 \\
\hline $\begin{array}{l}\text { Government } \\
\text { Industry }\end{array}$ & $\begin{array}{l}\text { Use } \\
\text { "Other } \\
\text { Svc." }\end{array}$ & 1.0000 & $\begin{array}{l}\text { Use } \\
\text { "Other } \\
\text { Svc." }\end{array}$ & 21.74 \\
\hline $\begin{array}{l}\text { Miscellaneous } \\
\text { Prod. \& Svcs. }\end{array}$ & $\begin{array}{l}\text { Use } \\
\text { "Other } \\
\text { Svc." }\end{array}$ & $\begin{array}{l}\text { Non-Comparable Imports }=0.00 \\
\text { Miscellany }=1.6265\end{array}$ & $\begin{array}{l}\text { Use } \\
\text { "Other } \\
\text { Svc." }\end{array}$ & $\begin{array}{l}\text { Non-Comparable Imports }=0.00 \\
\text { Miscellany }=10.70\end{array}$ \\
\hline
\end{tabular}


Table 4.2. Comparison of the Impact on Gross Output of a Hypothetical $\$ 100$ Investment in New Energy-Efficient Electric Motors Within the Pulp and Paper Industry (ACEEE Version of IMPLAN vs. ImBuild)

\begin{tabular}{|c|c|c|c|c|}
\hline Component of Impact & $\begin{array}{c}\text { ACEEE } \\
\text { Multiplier }\end{array}$ & $\begin{array}{c}\text { ImBuild } \\
\text { Multiplier }\end{array}$ & $\begin{array}{c}\text { ACEEE } \\
\text { Impact on } \\
\text { National } \\
\text { Output } \\
\end{array}$ & $\begin{array}{c}\text { ImBuild } \\
\text { Impact on } \\
\text { National } \\
\text { Output } \\
\end{array}$ \\
\hline $\begin{array}{l}\text { Investment Impact } \$ 100 \text { incremental motor } \\
\text { purchase }\end{array}$ & $\begin{array}{l}2.0310 \text { ("Other" } \\
\text { Manufacturing) }\end{array}$ & $\begin{array}{l}2.1398 \text { (Motors } \\
\text { and Generators) }\end{array}$ & $+\$ 203.10$ & $+\$ 213.98$ \\
\hline $\begin{array}{l}\text { Revenue Impact: }-\$ 100 \text { required to finance } \\
\text { the investment }\end{array}$ & $\begin{array}{l}2.1011 \text { (treated like } \\
\text { loss of current sales } \\
\text { by pulp and paper) }\end{array}$ & $\begin{array}{l}2.0827 \text { (reduced } \\
\text { business } \\
\text { investment) }\end{array}$ & $-\$ 210.11$ & $-\$ 208.27$ \\
\hline $\begin{array}{l}\text { Substitution impact: } \$ 50 \text { of savings on } \\
\text { utility bills }\end{array}$ & $\begin{array}{l}2.1011 \text { (treated like } \\
\text { increase in current } \\
\text { sales by pulp and } \\
\text { paper) }\end{array}$ & $\begin{array}{l}1.7361 \text { (average } \\
\text { impact of } \\
\text { commercial } \\
\text { energy savings on } \\
\text { output) }\end{array}$ & $+\$ 105.06$ & $+\$ 86.81$ \\
\hline $\begin{array}{l}\text { Displacement impact: }-\$ 50 \text { revenue loss by } \\
\text { utility sector }\end{array}$ & 1.7821 & 1.6978 & $-\$ 89.11$ & $-\$ 84.89$ \\
\hline Net impact & & & $+\$ 8.94^{(\mathrm{a})}$ & $+\$ 7.62$ \\
\hline $\begin{array}{l}\text { "Out Year" net impact (ignore investment } \\
\text { effects on lines } 1 \text { and } 2 \text { ) }\end{array}$ & & & $+\$ 15.95^{(b)}$ & $+\$ 1.94$ \\
\hline \multicolumn{5}{|c|}{$\begin{array}{l}\text { (a) Geller et al. would have shown a net impact of } \$ 38.90 \text {, had their investment been in the commercial sector, as their savings impact } \\
\text { depends critically on which sector experiences the savings. Our calculation depends on the items purchased, both for investment and with the } \\
\text { resulting savings, not which sector purchases them. Our estimate varies far less by sector. } \\
\text { (b) Taking an approximate average output multiplier of } 1.6 \text { for their commercial sector, Geller et al. would show a net impact of about - } \\
\$ 9.10 \text { for the commercial sector. }\end{array}$} \\
\hline
\end{tabular}

Geller et al. showed a net impact of $\$ 8.99$ in this instance in the first year and $\$ 15.99$ in subsequent years. Their impact multiplier for the original investment was Other Manufacturing, with a multiplier of 2.0310, for example, instead of the more narrowly defined Motors and Generators used here. The major difference, however, was in their paper mill example, where the multiplier used in lines 2 and 3 above was the 2.1011 figure for pulp and paper. In contrast, we finance the motor investment here with a reduction of $\$ 100$ that otherwise would have been made in gross private fixed investment (GPFI), distributed across all sectors. The multiplier is somewhat lower for GPFI taken as a whole than it is for a change in final demand for pulp and paper, but this is a more natural experiment than directly reducing the operating budget of a firm in the pulp and paper industry. ${ }^{(a)}$ Also, our substitution impact (calculated in Table 4.2) assumes that the savings in electricity are realized as 1) changes in the technology of the industry (a small reduction in the I-O matrix row coefficients pertaining to electric utility services and the commercial sector SIC codes) and 2) a corresponding increase in savings in the commercial sector industries. Such savings are distributed to labor, capital, and taxes according to historical patterns and

(a) Geller et al. (1992) assume that the $\$ 100$ premium on the motor was paid for by reducing the purchase of copier machines. If so, the proper way to have shown the impact on pulp and paper would have been to reduce final demand in the business machines manufacturing sector, not in pulp and paper. 
then spent on consumption, investment, and government activity. Again, in this case, the average impact multiplier is somewhat lower than that for pulp and paper.

Although they account for opportunity cost by temporarily reducing sector activity (line 2 in Table 4.2), Geller et al. (1992) were not sensitive to the question of financing the investment in energy saving, although there apparently were differences between the methods described in the text and those actually used. $^{\text {(a) }}$ As our analysis in Chapter 3 shows, that issue is not very important when the investment is no larger for the energy-conserving technology than for the conventional one. ${ }^{(b)}$ However, our analysis of the heat pump water heaters showed that, during the period when the energy efficiency investments are in progress, the size of the short-run macroeconomic impact can be strongly affected by the source of the investment funds (if the net difference in investment is large).

The central analysis of Geller et al. examined a high-energy efficiency scenario for all sectors in the U.S. economy to determine whether energy efficiency investments increased or decreased jobs and income. We have used ImBuild II to re-analyze the residential and commercial building sectors in Geller et al. and have obtained broadly compatible results for a similar scenario.

Table 4.3 shows our estimates of the impact of energy efficiency investments in the residential and commercial buildings sectors on the U.S. economy in 1990 dollars (for consistency with Geller et al. 1992). Impacts were calculated assuming that end-use savings were allocated to electricity, natural gas, and oil in the same proportions as in the original study (Alliance to Save Energy et al. 1991) on which Geller et al. is based. Because no data were available on how Geller et al. allocated incremental energy efficiency investments across sectors, we assumed the following distribution: residential and commercial construction 10\% each; lighting tubes and bulbs and other lighting and wiring, 15\% each; household cooking, refrigeration and laundry appliance manufacture, 5\% each; commercial laundry, computer and office equipment, and motors and generators, $5 \%$ each; and household and commercial heating equipment manufacture, $10 \%$ each. Financing was assumed to affect the whole economy in proportion to the amounts each sector historically represents: $70 \%$ personal consumption, $10 \%$ fixed investment, $2 \%$ federal defense spending, $6 \%$ federal non-defense spending, and $6 \%$ each for state and local government investment and operations. Energy efficiency in the residential and commercial sectors generated roughly $46 \%$ of the investment and $41 \%$ of the total national energy savings by value in all sectors in the Geller

(a) They show the financing as reduced final demand in the sector making the investment. A more correct procedure for financing is shown in the previous note. More generally, however, investment is often accomplished with borrowed funds, drawn from the economy as a whole. The corresponding multiplier may be quite different from that of the borrowing sector. Subsequent personal contact with Skip Laitner, the economist for the ACEEE project, reveals several differences between the example given in the text and the actual production runs of IMPLAN: a) about 80 percent of all improvements were financed at $10 \%$ over 5 years, with the balance assumed to be funded either through savings or retained earnings; $b$ ) the large reductions in demand would put a downward pressure on energy prices; c) sector-specific labor productivity improvements such that one million dollars saved in ten years hence (measured, of course, in constant dollars), would have a reduced labor impact as a result of ongoing productivity gains); d) program costs of 15 percent of investment would be needed to drive the results of the scenario.

(b) A differential effect could result if the investments amounts were identical, but the processes that manufactured and installed the two technologies were very different. 
et al. (1992) analysis. Not too surprisingly, we show energy efficiency in residential and commercial buildings alone generates about $60 \%$ of the employment and $24 \%$ of the total income impacts reported by Geller et al.(1992) for all end use sectors combined. (Besides residential and commercial buildings, Geller et al. include the transportation, utility, and industrial sectors.) The impacts would vary somewhat, depending on exactly which sectors are affected and to what degree. With the particular assumptions used, if utility sector capital investment can be saved as a result of improved energy efficiency, the employment impacts shown in Table 4.3 would be higher than shown by about $16 \%$ and the income effects also about $16 \%$ higher.

Table 4.3. Economic Impact of High Efficiency Investments in the Residential and Commercial Buildings Sectors on the U.S. Economy

\begin{tabular}{|c|c|c|c|c|c|c|}
\hline & \multicolumn{3}{|c|}{$\begin{array}{c}\text { ImBuild (Residential and } \\
\text { Commercial Buildings Only) }\end{array}$} & \multicolumn{3}{|c|}{ Geller et al. 1992 (All End-Use Sectors) ${ }^{(a)}$} \\
\hline & 2000 & 2005 & 2010 & 2000 & 2005 & 2010 \\
\hline Investment (Billion 1990 \$) & $\$ 14.5$ & $\$ 27.3$ & $\$ 27.7$ & $\$ 35.1$ & $\$ 59.0$ & $\$ 59.7$ \\
\hline Energy Savings $\left(10^{15} \mathrm{Btu}\right)$ & 1.9 & 4.2 & 6.6 & 7.5 & 14.1 & 20.8 \\
\hline \multirow[t]{2}{*}{$\begin{array}{l}\text { Value of Energy Savings } \\
\text { (Billion } 1990 \$ \text { ) }\end{array}$} & $\begin{array}{l}\text { Res. } \\
\$ 15.4\end{array}$ & $\begin{array}{l}\text { Res. } \\
\$ 28.8\end{array}$ & $\begin{array}{l}\text { Res. } \\
\$ 42.5\end{array}$ & & & \\
\hline & $\begin{array}{c}\text { Comm. } \\
\$ 5.2\end{array}$ & $\begin{array}{c}\text { Comm. } \\
\$ 15.4 \\
\end{array}$ & $\begin{array}{c}\text { Comm. } \\
\$ 25.8\end{array}$ & & & \\
\hline Total & $\$ 20.6$ & $\$ 44.2$ & $\$ 68.3$ & $\$ 54.8$ & $\$ 109.9$ & $\$ 167.0$ \\
\hline $\begin{array}{l}\text { Net Impact on Employment } \\
\text { (Thousand Jobs) }\end{array}$ & 198 & 420 & 647 & 471 & 776 & 1087 \\
\hline $\begin{array}{l}\text { Net Impact on Income } \\
\text { (Billion } 1990 \text { \$) }\end{array}$ & $\$ 2.5$ & $\$ 5.1$ & $\$ 6.9$ & $\$ 10.7$ & $\$ 20.2$ & $\$ 28.5$ \\
\hline \multicolumn{7}{|c|}{$\begin{array}{l}\text { (a) Although Geller et al. } 1992 \text { provide some details on investments for residential and commercial end-use sector energy efficiency and } \\
\text { resulting energy savings, insufficient data was presented on the allocation of these investments to each SIC sector or the impacts on } \\
\text { output, employment and income attributed to each end use sector to permit a side-by-side comparison for the impacts of the residential } \\
\text { and commercial sector investments alone. }\end{array}$} \\
\hline
\end{tabular}

\subsection{Comparisons to Recent Studies}

One recent study similar to Geller et al. (1992) is Laitner et al. (1998), in which a later version of the IMPLAN model and the National Energy Modeling System (NEMS) were used to estimate employment and other macroeconomic impacts of an "innovation-led" climate strategy for the United Sates. In this study, an energy-efficient, low-carbon future of the economy is developed through a series of sectorspecific energy policies and programs, such renewable content standards, emissions performance allowances, an advanced vehicles initiative, investment tax credits, information programs, market transformation activities, and appliance and building standards. NEMS and auxiliary analyses estimated the incremental costs and savings to the U.S. economy, while IMPLAN was used to estimate the resulting effects on Gross Domestic Product, employment and wage income. Laitner et al. made several modifications made to the standard IMPLAN analysis: a) 10\% of efficiency investments would be outside 
of the United States; b) forecasted annual increases in labor productivity were used to reduce the employment impacts associated with any given change in sector output; c) about $80 \%$ of the investment upgrades were assumed to be financed with bank loans; and d) government program and marketing expenditures were assumed to be necessary to achieve the efficiency investments recorded in the building and appliance sectors. These costs were projected at 15\% of the efficiency investments.

Because Laitner et al. supplied their input data only in summary form, it was not possible to compare analyses directly by running ImBuild II using the same assumptions.

\subsection{Comparisons to Additional Studies}

Geller et al. (1992) report on a number of other regional, state, and national studies that have attempted to estimate economic impacts of energy efficiency programs. For example, they report that in 1984 Charles River Associates evaluated the regional employment impacts of weatherization programs for the Bonneville Power Administration using an I-O model, contrasting one million $\mathrm{kWh}$ provided by weatherization versus one million $\mathrm{kWh}$ provided by nuclear power. The key finding of that study was that rate increases would lead to net regional job losses from nuclear power (-31 jobs per 1 million $\mathrm{kWh}$ ), but that weatherization contributes slightly more jobs than it subtracts through rate increases (about +2 jobs per 1 million $\mathrm{kWh}$ ). As with the findings of the current study, if by saving energy the utility industry can avoid increased energy costs that result from investment in new capacity, the impact on jobs is positive. This situation would be especially true for a relatively labor-intensive energy efficiency program such as weatherization. It would be particularly true at the regional level, where the funds for energy efficiency investment would not necessarily come from the regional economy. In that case, the region would, in effect, import capital and jobs from somewhere else and another region would bear the opportunity costs. In effect, this case would be one where "financing is costless" and "utility capital expenditures are saved." Relatively high positive employment impacts would be expected and were found. It is not clear which way the effects would go at the national level, as the model would be closed with respect to the capital investment funds on the one hand, but the multiplier effects should be larger on the other.

In a Canadian study, Jaccard and Sims (1991) looked at the employment effects of energy and hydropower in British Columbia. The cost of saving electricity in this case was estimated at 1.9 cents per $\mathrm{kWh}$ and the cost of new hydroelectric power was estimated at 5 cents per $\mathrm{kWh}$. The net employment impact was positive (600 jobs per year), in large part because the direct cost of power was lower. Again, this study was regional, but the net effects would not necessarily have been smaller at a national level, because the source of regional funding for either weatherization or hydropower might have been the same. The ImBuild II model shows positive employment impacts from energy cost savings of about 10.5 jobs per million dollars worth of residential electricity saved, before accounting for either positive or negative investment effects.

The Council on Economic Priorities of the State of New York looked at the effects of 32 residential energy and conservation options in 1979 (Buchsbaum et al. 1979) using the Department of Commerce RIMS model and the National Economic Growth Model of the Bureau of Labor Statistics. The cost of the residential measures was estimated at $\$ 4.0$ billion over 38 years. They found that conservation and solar 
technologies would create up to 1.4 times as much national employment as a nuclear power plant or about 10,000 to 13,000 jobs nationally. Running ImBuild II for a $\$ 4.0$ billion investment (in 1979 dollars) over 38 years ( $\$ 105$ million per year) in energy saving technology to save an average $1000 \mathrm{MW}$

(5.7 billion $\mathrm{kWh}$ or 19.4 trillion Btu) at 5 cents per $\mathrm{kWh}$ (1979 dollars) generates an increase of about 5,100 jobs nationally. At 10 cents per $\mathrm{kWh}$ saved, the net job creation is about $10,300^{(\mathrm{a})}$, roughly the same as the Council on Economic Priorities figures.

A 1992 Missouri study found that cost-effective conservation resources could save about 100 trillion Btu per year (Laitner 1992). In the year 2000, an investment of $\$ 5$ billion ( $\$ 1$ billion per year over 5 years) would create about 8,000 to 13,000 new jobs for the state, increasing wages and salaries by $\$ 300$ million. When ImBuild II is run with a $\$ 1$ billion per year investment (in 1992 dollars) for 5 years, the energy savings associated with the initial national impact create about 11,200 jobs and \$162 million in wages (in 1992 dollars), allowing for the national opportunity costs of the invested funds. This solution is broadly consistent with the local Missouri figures, as some impacts would be out-of-state. In the longer term, about 11,900 jobs net and \$118 million in wages (in 1992 dollars) are created nationally by the energy savings associated with the investments. ${ }^{\left({ }^{b}\right)}$

In general, therefore, the ImBuild II results are roughly comparable to those of other recent analyses.

(a) We assumed \$105 million in additional investment, adjusted to 1992 dollars from 1979 dollars, distributed as residential and commercial construction $10 \%$ each; lighting tubes and bulbs and other lighting and wiring, $15 \%$ each; household cooking, refrigeration, and laundry appliance manufacture, $5 \%$ each; commercial laundry, computer and office equipment, and motors and generators, $5 \%$ each; and household and commercial heating equipment manufacture, $10 \%$ each. Annual energy savings were based on an average load factor of 0.65 .

(b) A total of 100 trillion Btu were assumed divided 25\% each for residential and commercial natural gas and electricity. Investment was distributed residential and commercial construction $10 \%$ each; lighting tubes and bulbs and other lighting and wiring, $15 \%$ each; household cooking, refrigeration, and laundry appliance manufacture, $5 \%$ each; commercial laundry, computer and office equipment, and motors and generators, $5 \%$ each; and household and commercial heating equipment manufacture, $10 \%$ each. Delivered energy prices were assumed to be \$19-\$21 (in 1992 dollars) per Mbtu for electricity and \$5 per Mbtu for natural gas. 


\subsection{Operating the ImBuild Model}

To use IMBUILD a user would necessarily have had to install the software with the SETUP.EXE program provided. This will ensure that all components of the model are properly installed. Once installed on a desktop PC the user starts the program as per normal Windows program methods.

Once started the IMBUILD program will display an introductory splash screen, then present the user with an introductory instructions screen. The user should select Continue to advance to the main "Run specifications" screen. It is in this screen that the user will add records to represent specific program assumptions.

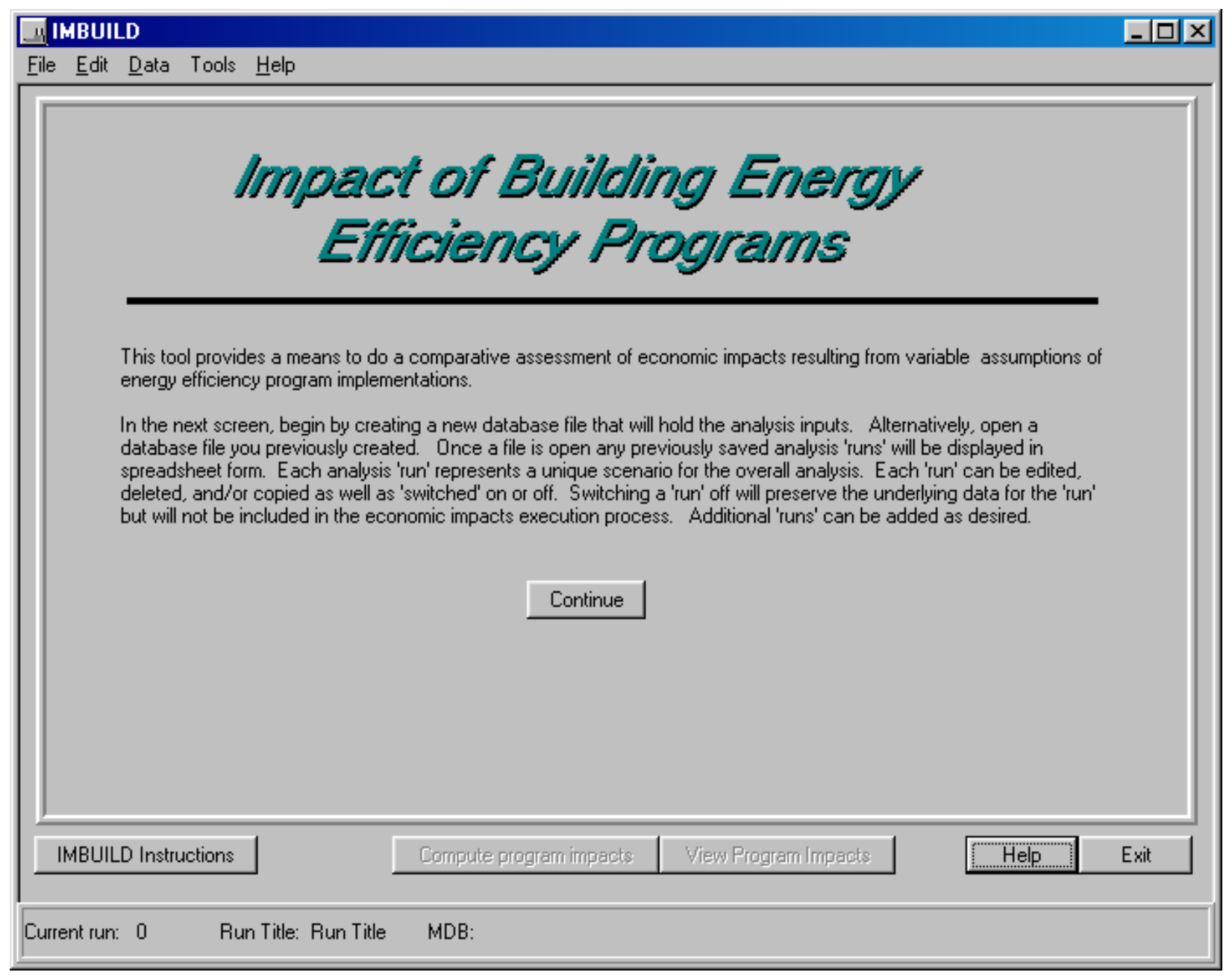

Figure 5.1. ImBuild Title Page 


\subsection{ImBuild Options}

The "Run specification" screen is used to specify unique program scenarios. Add as many records as there are unique scenarios to be compared. Only the records that have "Execute run" checked will be run and displayed in the results screen. Before specifying "run specifications" the user must first create a new "run database" using the menu options under the "File" menu. The "run database" will hold all information and results specific to the scenarios established and specified. Thus, a user can make any number of "run databases" for specifying unique scenarios.

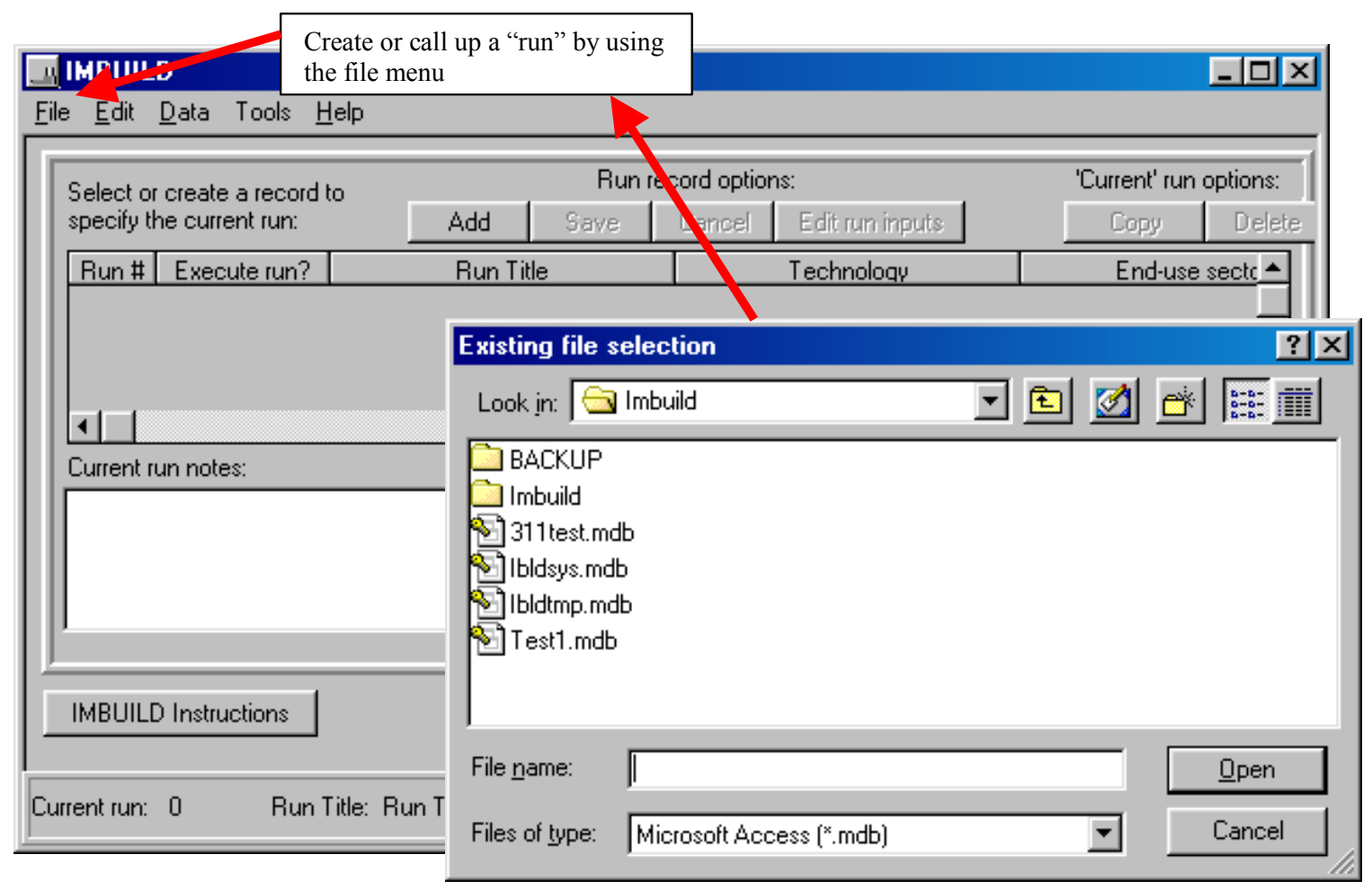

Figure 5.2. Run Specifications Screen

The "Run specification" screen is used to specify unique program scenarios. Add as many records as there are unique scenarios to be compared. Only the records that have "Execute run" checked will be run and displayed in the results screen.

Functionality of this screen is described below:

Add - Adds a "run" record to the spreadsheet.

Save - Saves the current "run specification" records to the currently opened database file.

Cancel - Cancels any changes to the "run specification" spreadsheet and refreshes the display.

Edit run inputs - Displays a screen of detailed "run inputs" that can be edited by the user.

Copy - Copies the currently selected "run record" (indicated by yellow marker in left most column and/or in status bar at the bottom of the screen. 
Delete - Deletes the currently selected "run record" from the spreadsheet and the database. A "confirmation prompt" will be displayed to verify the request. The "confirmation prompt" can be "turned off" for future deletions by checking the appropriate check box in the "confirmation prompt" screen.

IMBUILD instructions - Simply introductory instructions will be displayed.

Compute program impacts - Computations of program/technology impacts will be run on all "run specifications" that have the "Execute run" column checked. After computations are done the results screen will be displayed.

View program impacts - Displays the results screen without running computations. Results will be displayed for the last computed impacts.

Help - Displays the help file.

Exit - Exits the IMBUILD program.

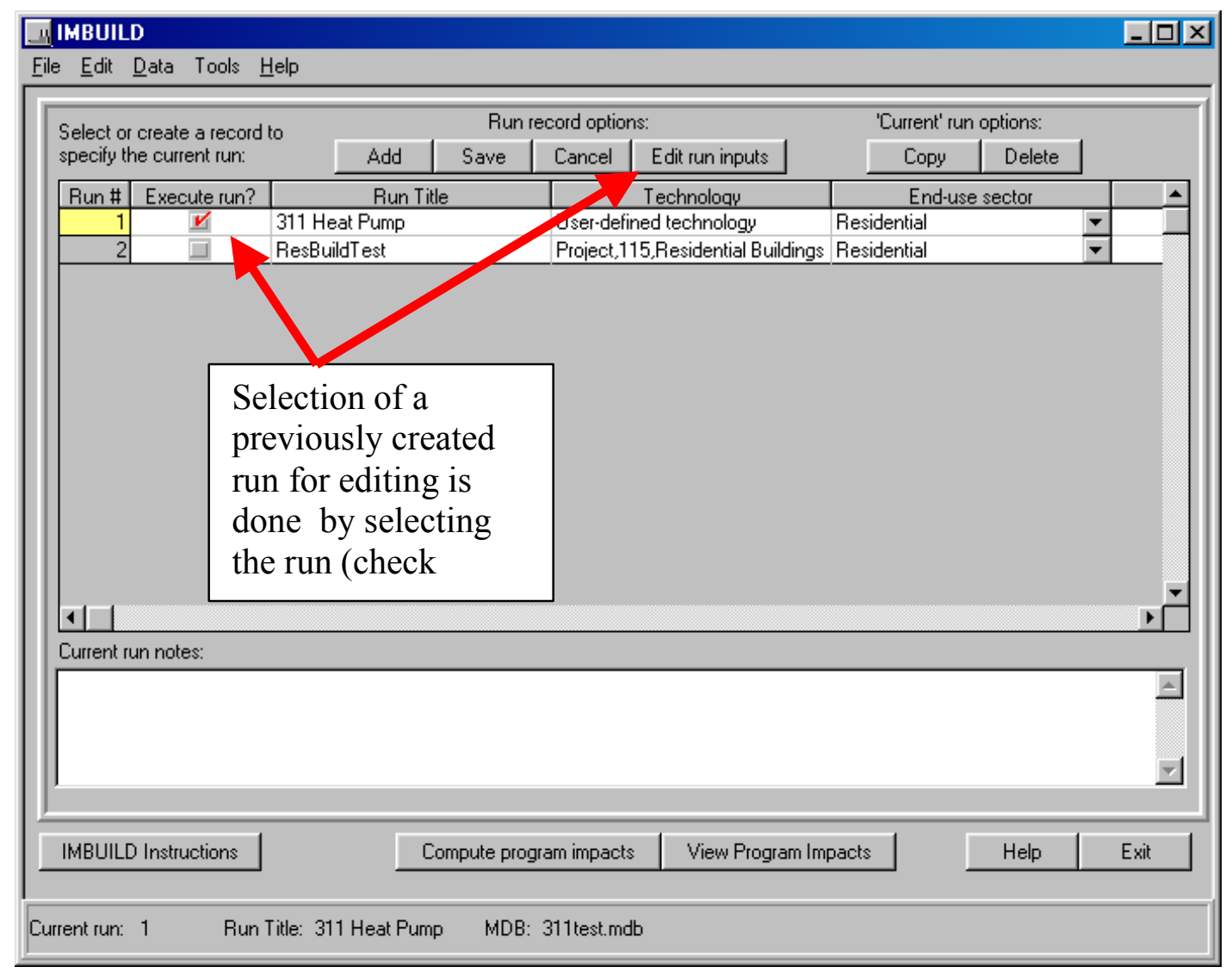

Figure 5.3. Run Specification Spreadsheet

\section{"Run specification" spreadsheet columns -}

Run \# - A unique identifier for a "run specification" record. This is a non-editable column and is determined programmatically.

Run title - User provided description of the "run specification". 
Technology - The technology/program that is assigned to the "run specification". When a "run specification" record is added the technology list will be displayed as a drop-down list containing all default technologies/programs. Select the appropriate choice.

Note: you cannot change your technology choice after you have saved the "run specification" record. However, after saving the record, you can edit the technology description and edit its underlying data and/or copy the edited technology to another "run specification" record.

End-use sector - Identifies the appropriate end-use sector for the "run specification" record. The selection determines what set of economic sector distribution factors you will have access to in the "run inputs" screen.

User name - User provided name for reference purposes only.

Date - User provided date for reference purposes only.

Last run time - Indicates the time the record impacts were last evaluated.

Last run date - Indicates the date the record impacts were last evaluated.

If a new "run database" has been newly created it will appear without any "run specification" records. Click the "Add" button to add a new record then fill in the cells. All cells except user name and date must be specified. Select "Save" to save any new records or changes to existing "run specification" records. To access the underlying economic and technical data of the "run specification" record, select the "Edit run inputs" button and review/edit the data as needed.

When all data have been specified the user should select "Compute program impacts" to do the actual calculations and display the results. Note that only those "run specification" records that have "Execute run" checked will be included in the calculation process and displayed in the results screen. If there are no changes since the last calculations were run and the user simply wants to review the results then select the "View program impacts" button.

\subsection{Technology Data}

The technology data spreadsheet is used to specify the incremental programmatic impacts on capital cost, installation cost, energy or resource cost, O\&M cost, and energy or resource savings. The appropriate units for each are displayed in the row headings. Note that all data are specific to the "run specification" described in the drop-down list at the top of the screen. Furthermore, the rows that are displayed in the spreadsheet are dependent on the "end-use sector" that is selected for the "run specification". To see other technology data select a different "run specification" record at the top of the screen.

Add technology to list of default technologies - Enables the user to add a technology to the "default" technology list. This feature allows the user to establish customized versions of a technology that can then be used repeatedly when adding new "run specification" records. More specifically, the user may have a particular set of technology data and years that are not currently represented in the "default" technology list. To create a new "default" technology simply select an existing "default" technology, modify its data accordingly, save any changes, then select the "Add technology to list of default technologies" pop-up choice. You would then see a new "Add technology" screen appear in which you 


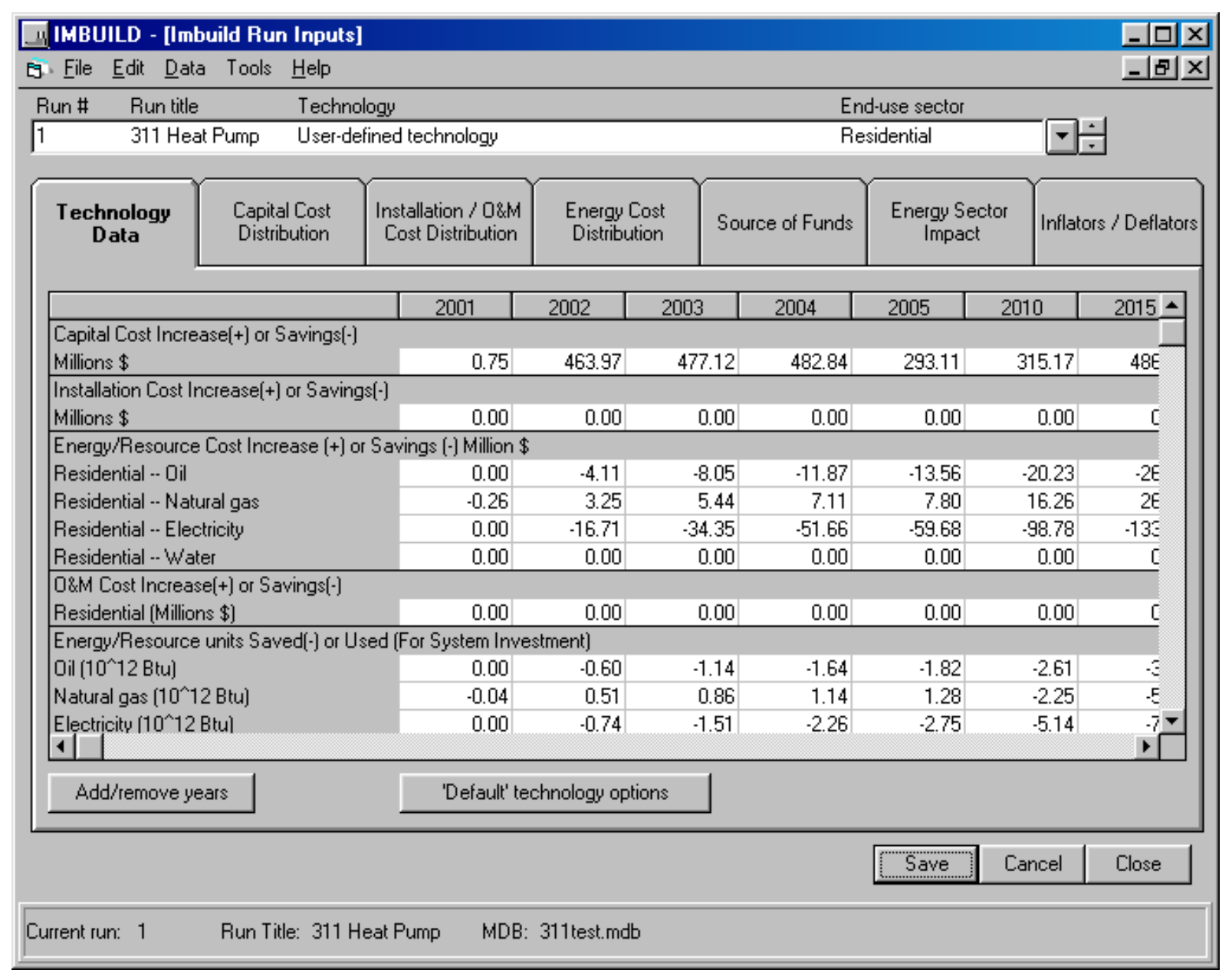

Figure 5.4. Technology Spreadsheet

enter a unique technology name where requested then select "Add" and "Close". At this point you can return to the "run specification" screen and if you add new "run specification" records the newly created technology will appear in the drop-down list of "default" technologies.

\subsubsection{Technology Data}

The technology data spreadsheet is used to specify the incremental programmatic impacts on capital cost, installation cost, energy or resource cost, O\&M cost, and energy or resource savings. The appropriate units for each are displayed in the row headings. Note that all data are specific to the "run specification" described in the drop-down list at the top of the screen. Furthermore, the rows that are displayed in the spreadsheet are dependent on the "end-use sector" that is selected for the "run specification." To see other technology data select a different "run specification" record at the top of the screen. 
The data on the technology data screen can be input or edited by hand. The years covered by the scenario also can be adjusted. Note that all costs or savings are considered to relate to differences from the conventional competing technology. For example, in example shown in Figure 5.4, the technology costs the economy an additional $\$ 463.67$ million in investment during the year 2002. The annual level energy and water impact in the same year is $\$ 4.11$ million saved in oil, an additional $\$ 3.25$ million used in natural gas, \$16.71 million saved in electricity, and no change to water use or non-energy operating costs. The energy, water, and operating cost savings are annual levels in the year shown that depend on cumulative investments. The capital costs are the cash investments in the year shown. This accounting is required by the input-output model's requirements for annual cash flow.

The following are some key functions:

"Advanced technology options" - Enables the user to add a technology to the "default" technology list and/or delete technologies from the "default" technology list. This feature allows the user to establish customized versions of a technology that can then be used repeatedly when adding new "run specification" records.

"Add/remove years" - Enables the user to add and/or remove years from the currently displayed "run specification".

Note: The choices only affect the currently displayed "run specification". Before "runs" can be processed all "run specifications" must have the same set of years.

\section{Changing the default technology options}

Add technology to list of default technologies - Enables the user to add a technology to the "default" technology list. This feature allows the user to establish customized versions of a technology that can then be used repeatedly when adding new "run specification" records. More specifically, the user may have a particular set of technology data and years that are not currently represented in the "default" technology list. To create a new "default" technology simply select an existing "default" technology, modify its data accordingly, save any changes, then select the "Add technology to list of default technologies" pop-up choice. The user would then see a new "Add technology" screen appear in which he enters a unique technology name where requested, then select s "Add" and "Close". At this point return to the "run specification" screen. If the user adds new "run specification" records, the newly created technology will appear in the drop-down list of "default" technologies.

Delete technology from list of default technologies - Enables the user to delete technologies from the "default" technology list. Note: the deletion of a technology only affects the "default" technology list and in no way deletes records from the user database file. 


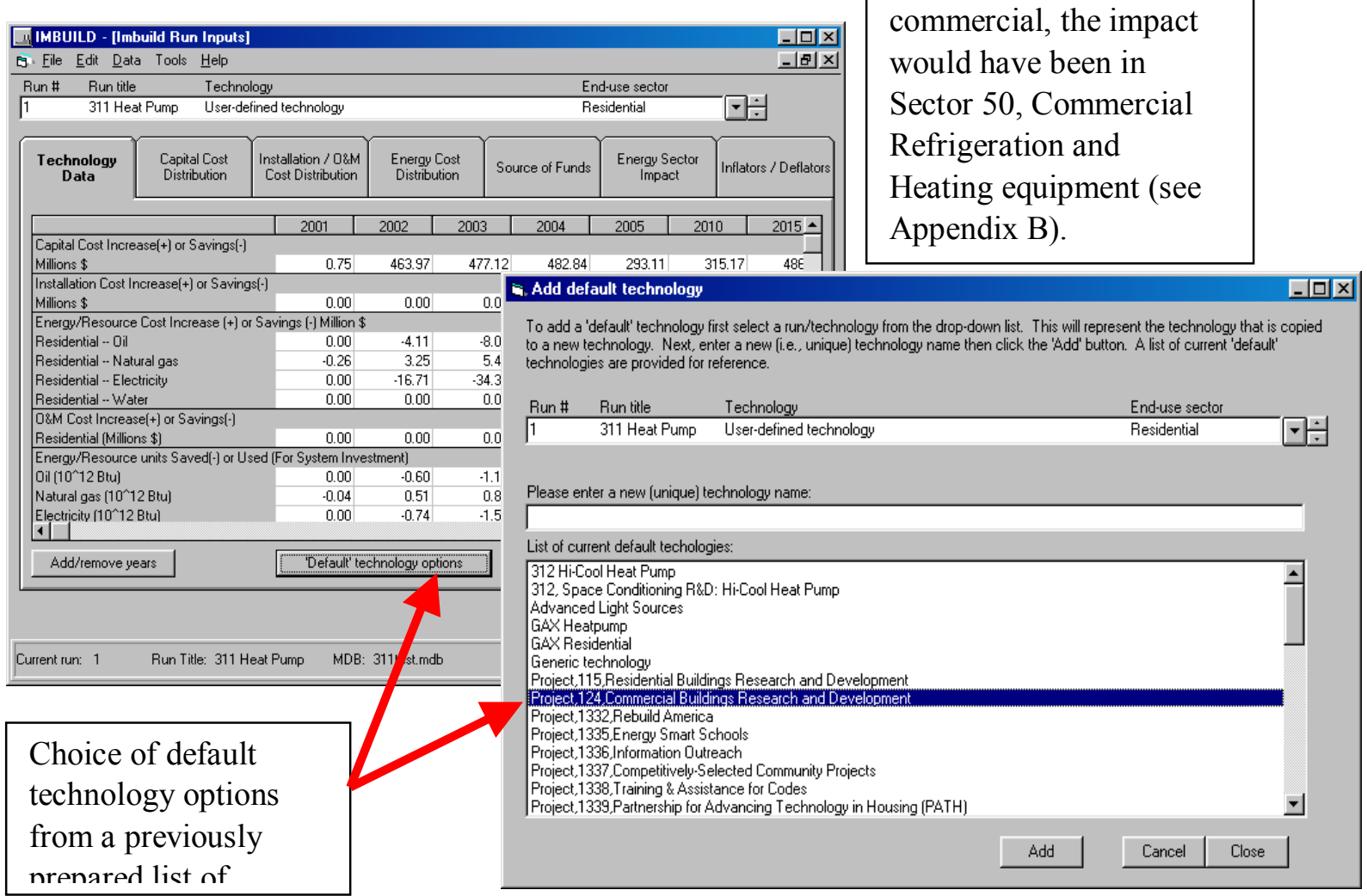

Figure 5.5. Adding to the Technology Options

\subsubsection{Capital cost distribution}

Enter the percentage values (enter $50 \%$ as 50 ) that represent the distribution of capital cost premiums for the applicable sectors. The total of all values must equal 100. In the example shown in Figure 5.6, $100 \%$ of the capital cost premium is spent on heating equipment (Sector 39).

\subsubsection{Energy and Water Cost Savings Distribution}

Enter the percentage values (enter $50 \%$ as 50 ) that represent the distribution of energy and water cost savings for the applicable sectors. The total of all values must equal 100. Note that the sectors shown will be dependent on the end-use sector targeted by the technology/program. For example, commercial end-use sectors will be the sectors numbered 82 through 95, industrial end-use sectors will be sectors 1 
through 72, transportation will be sectors 73 through 77. Residential end-use technology/program cost savings will all impact final demand; thus, there will be no industry sectors to specify.

In the original version of ImBuild, energy savings in commercial buildings were allocated to sectors 82 through 95 in proportion to each sector's baseline purchase of each fuel; e.g., if Sector 82, Wholesale and Retail Trade, purchased 30.00 percent of electricity purchased in sectors 82 though 95 , Sector 82 would have seen 30.00 percent of the savings as well. The user is now free to change these proportions. The new model also includes water cost savings. This is important for some water-using equipment such as laundry equipment.

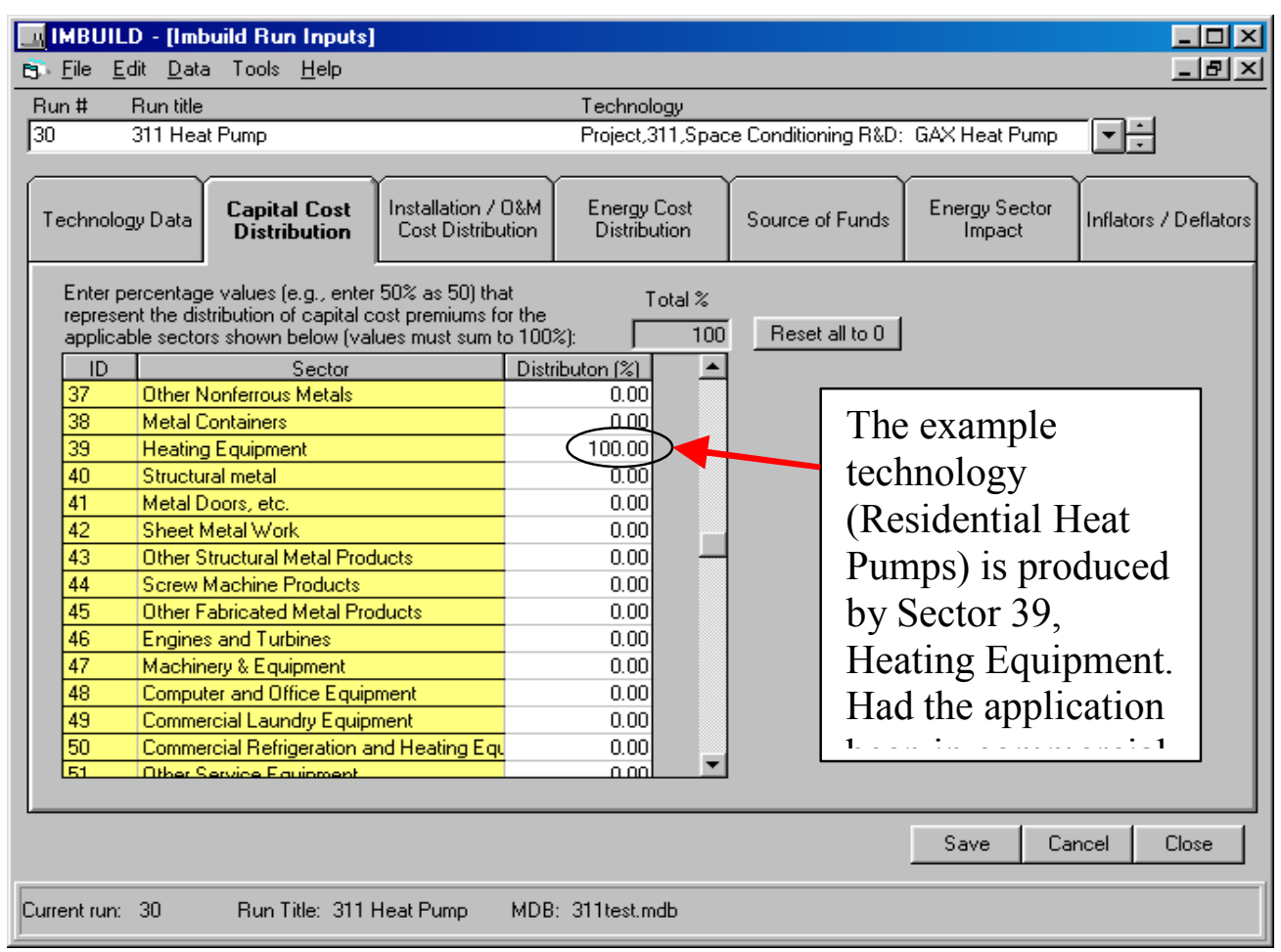

Figure 5.6. Allocation of Capital Cost 


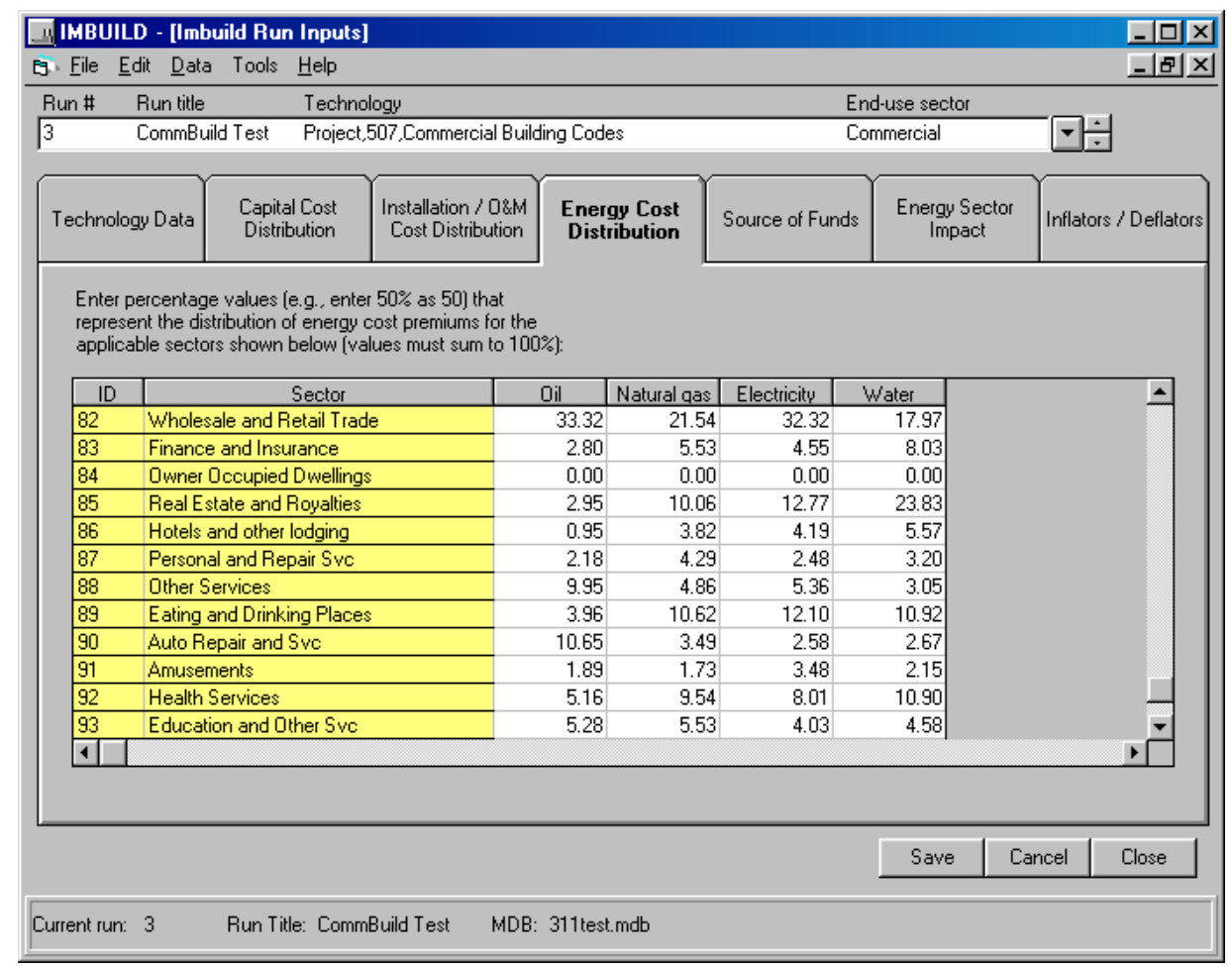

Figure 5.7. Energy Cost Savings Distribution Across Sectors

\subsubsection{Source of Investment Funds}

Investment funds spent on energy-efficient equipment have an opportunity cost; that is, they would have been spent somewhere else in the domestic economy or overseas if they were not spent on energyefficient equipment. The source of funds sheet allows the user to specify the source of the funds used for investment. Enter the percentage values (e.g., enter 50\% as 50) that represent the share of investment funding provided by each applicable. The sum of the sector allocations does not need to equal $100 \%$, but if it does not, the model will allocate the remaining percentage to sum to $100 \%$ unless it is overridden, and will allocate spending reductions within the remainder using the average proportions in all final demand. However, even if all of the explicit shares are set to zero, each sector will have its spending reduced by the proportion it represents of all final demand unless the override box is checked. The override check box allows some or all of the opportunity cost of invested funds to not be counted against domestic final demand. There are occasions when the user may not want to consider the opportunity cost of the funds used for investment. If, for example, only the impacts on a local region were being considered and the funds came from the national financial markets, then the local area might see the positive impact of the investment as well as any energy savings, but would not experience the costs to the national economy. These costs would be "somewhere else." Another reason might be if the displaced spending were somewhere else in the world and only the domestic impact was important. If opportunity cost of the investment funds is irrelevant to the analysis or the source of funds is "magic," then all values can be set to 0 . To do this, set all of the sectors to zero, check the check box, and then set the remainder box to zero as well. 
The most common assumption is that investment funds will come proportionately from all domestic spending.

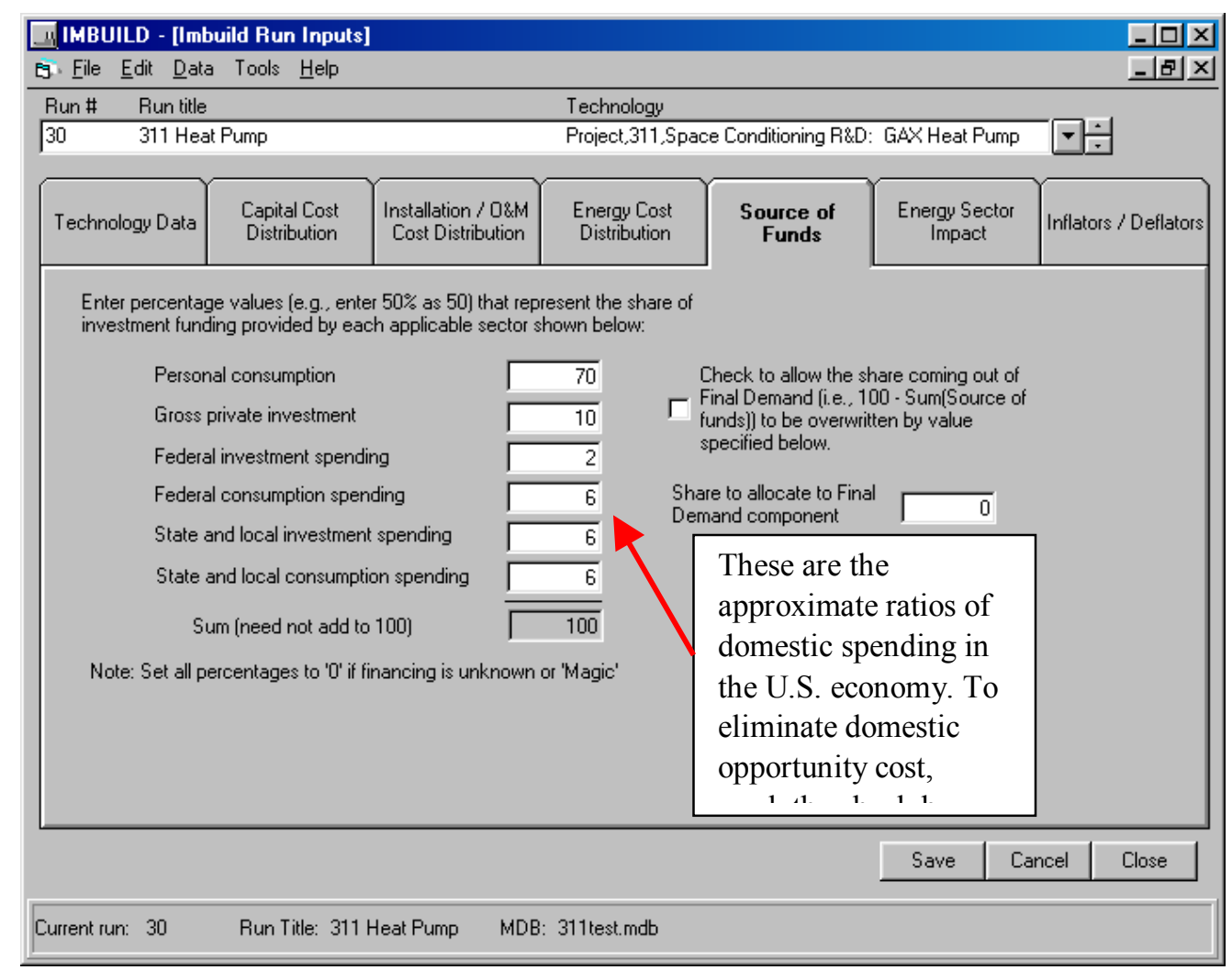

Figure 5.8. Opportunity Cost of Invested Funds

\subsubsection{Energy Sector Impact}

This screen allows the user to specify how the technology/program impacts will affect the investment in the energy sector, in particular the electricity and industries. Significant energy savings might allow electricity and natural gas production, transmission, and distribution companies to reduce the amount of investment that they undertake, which frees up investment capital for the general economy (this is the mirror image of the "source of funds" allocation). If reductions in investment occur due to the technology/program then enter "Yes" for the applicable question and enter any changes to load/capacity factors and costs as necessary. If either "Yes" is selected then enter where (percentage shares) investment dollars would be going to (what sectors would benefit) in the right hand box. In the example in Figure 5.9, the investment is proportionately distributed to the economy as a whole. Note that in this case the sum of those shares is handled the same way as the as the opportunity cost of invested funds. The "benefit" of investment savings need not remain in the region of interest. 


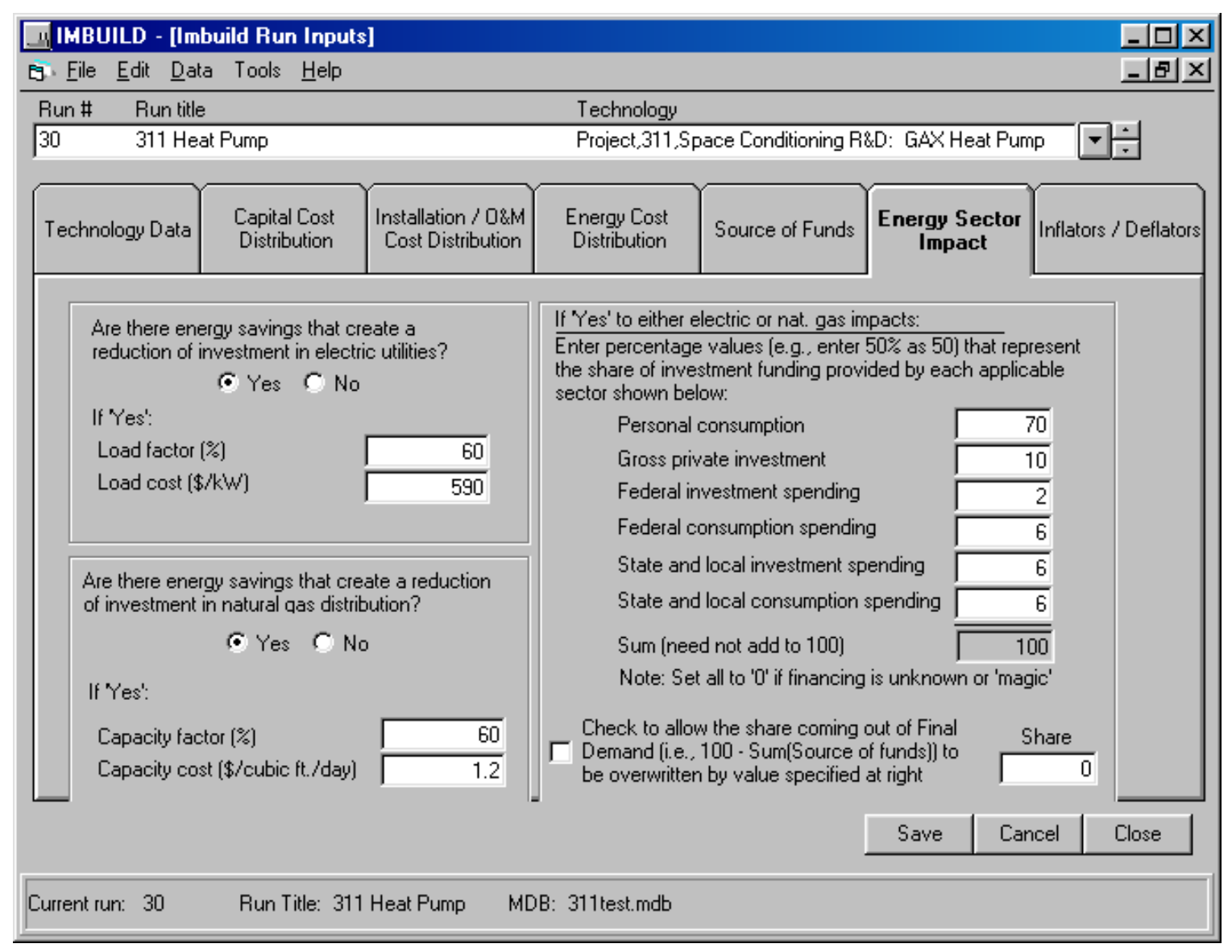

Figure 5.9. Impact of Energy Savings on Energy Sector Investments

\subsubsection{Inflators/Deflators}

The inflators/deflators page is designed to allow easy conversion of costs and savings to the appropriate year's dollars. The input-output table at the core of ImBuild is in 1992 dollars, so inputs to the model need to be converted to a 1992 basis. For example, in the first version of the ImBuild model, capital costs and savings were in 1995 dollars, which needed to be converted to 1992 dollars. This is the purpose of the deflators. On the other hand, for reporting purposes many users would like to see earnings numbers in some later year's constant dollars, not 1992. For example, in recent use of the model, results have been reported in constant 1999 dollars. This is the purpose of the inflators. Enter the appropriate inflators /deflators to use in the model. Note that capital cost deflators are used to adjust capital cost, installation costs, and utility impact costs to the base input-output year (1992). Operations cost deflators are used to adjust energy costs and O\&M costs to the base input-output year and to adjust the base inputoutput results for 'output' dollars back to the year assumed by the technology data. Both of these are based on Gross Domestic Product deflators. The inflator input is based on the appropriate year's Consumer Price Index and is used to adjust base input-output results for earnings to the technology data base year, or to some other year for reporting purposes. 


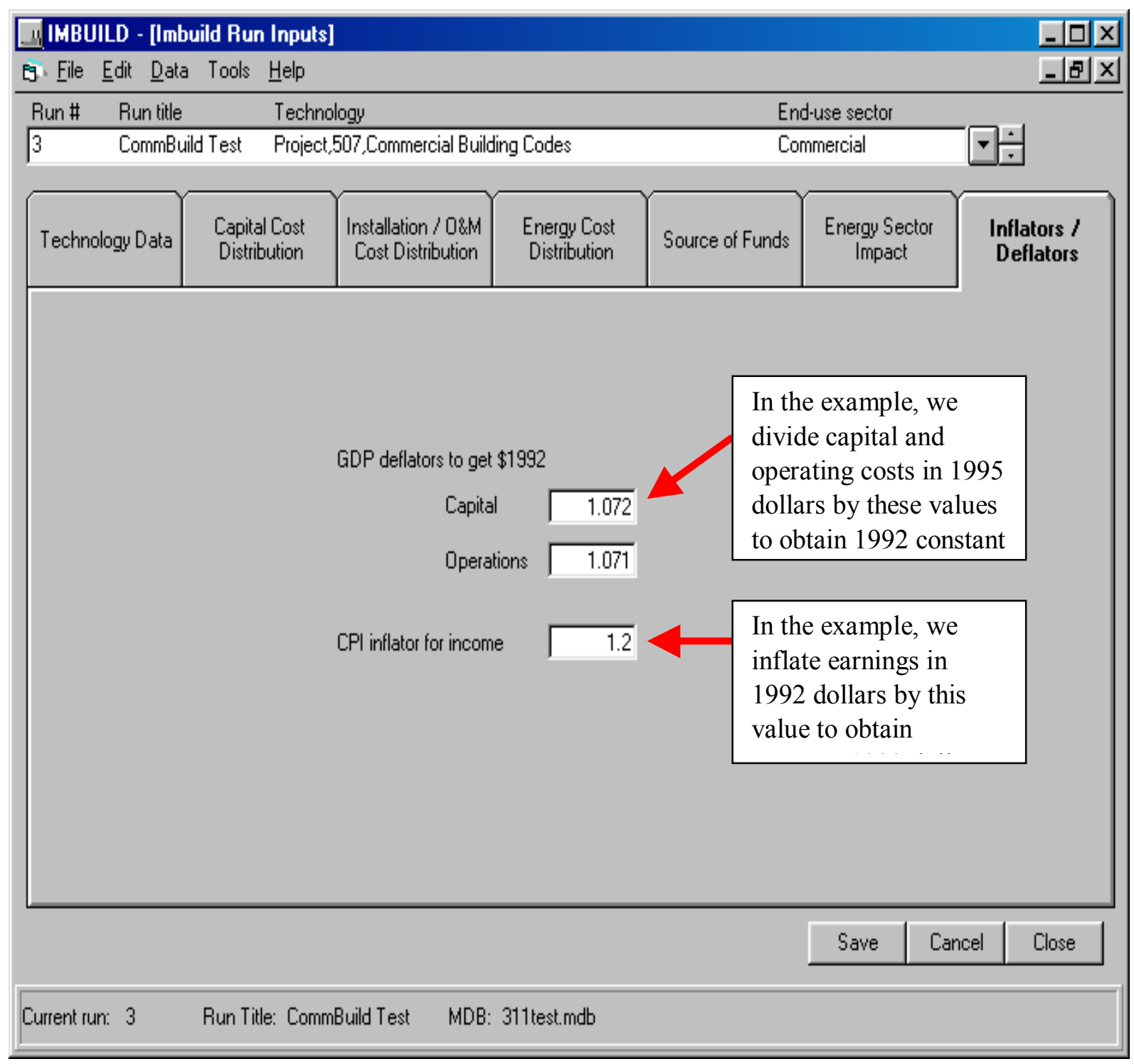

Figure 5.10. Assigning Inflators and Deflators

\subsection{Computing Program Impacts}

Selecting the "Compute program impacts" will run the computations for determining the impacts of the "run specifications". Only those records marked with "Execute run" will be processed. Before running computations the program checks for a common set of years between all technologies/programs. It will also test for conditions where there are no years represented. 
With data integrity checks complete, the process loops through each "run scenario" and, in turn, creates an associated ASCII file of data that will be read by the ImBuild model. The processing code (QMIO.EXE) is then called and when finished, the process retrieves the ASCII output file created by the model and parses and stores the results to the user database file. With that process complete, the IMBUILD tool opens the results screen and presents the calculated impacts in spreadsheet and graphical form.

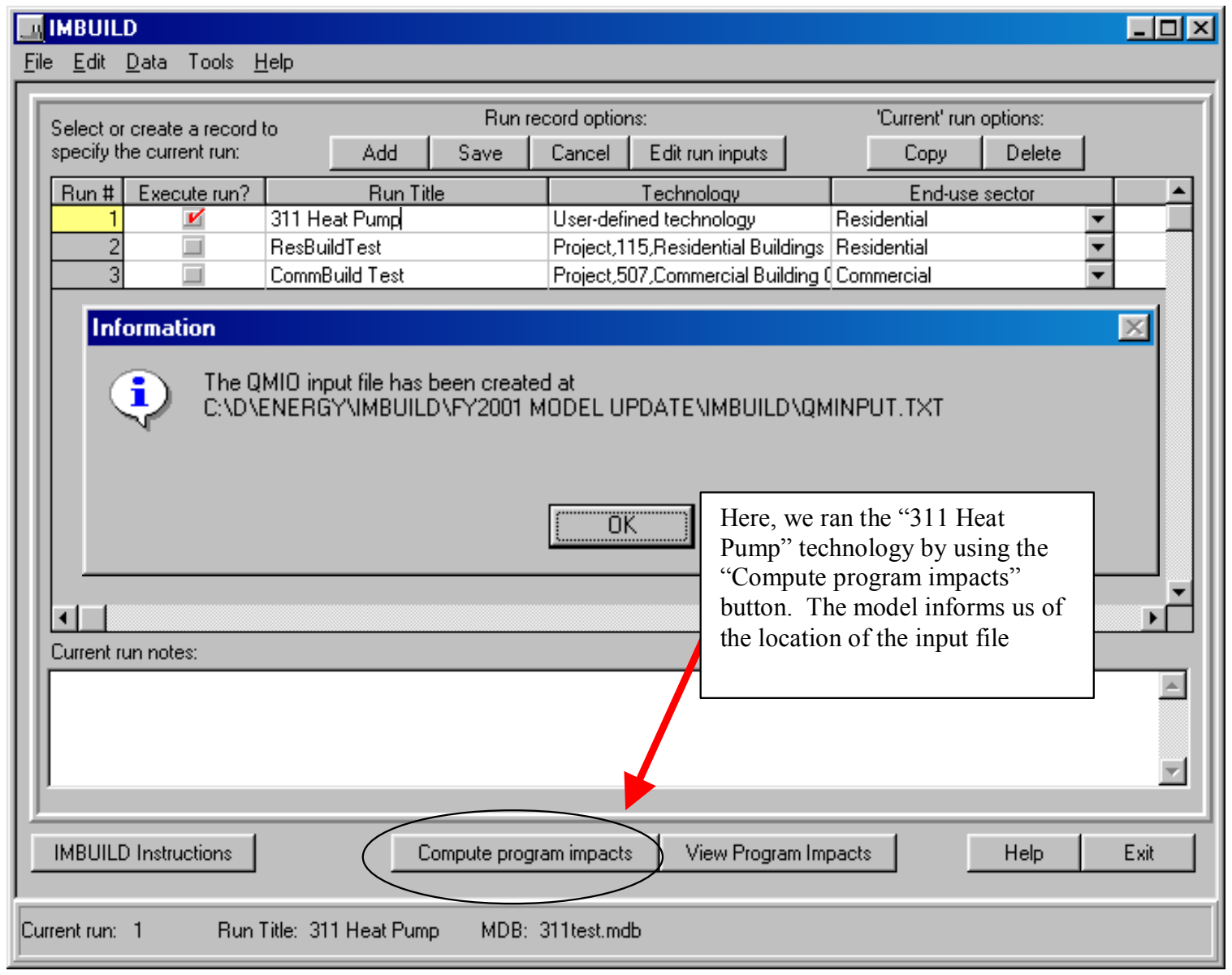

Figure 5.11. Running the ImBuild Model

\subsection{Viewing Program Impacts}

If the user wishes to view the last computed impacts without rerunning the calculations then he/she should select the "View program impacts" button. The results can be viewed in two display formats. The first will be in a spreadsheet form and second will be a graphical form. In either form the displayed data will be dependent on the "Impacts data type" choice that is available at the top of the screen. Additional options in this screen include printing the spreadsheet and all the data types and exporting all impact data types to an Excel spreadsheet file. The name assigned to the Excel file will be the same as the user database file. The graphical portion of the "Results" screen offers the user a rich set of options for 
changing the graph displayed. The user should feel free to "play" with the different option available including printing the graph to file or printer.

\section{Results presentation}

There are two styles of results presentation. The first style shows the results in tabular form and in graphical form presented in individual "tab" frames. Use the "Results type" drop-down list at the top of the screen to select the individual results data that are available. Select the "Print" button to print these as they appear on the screen. In this presentation style the user has liberty to access the graph properties pages to customize and print the graph in a customized fashion. The user also has the option of selecting which results to graph by selecting the appropriate button. The second results presentation is made available by clicking the "Reports manager" button in the "Results" screen. The "Report Manager" screen will present a spreadsheet contained all available reports. Each of these types of reports will display both a graph (Table 5.12) and cross-tabbed table (Table 5.13) of the selected results. This presentation of the results enables the user to export the results to a host of file formats.

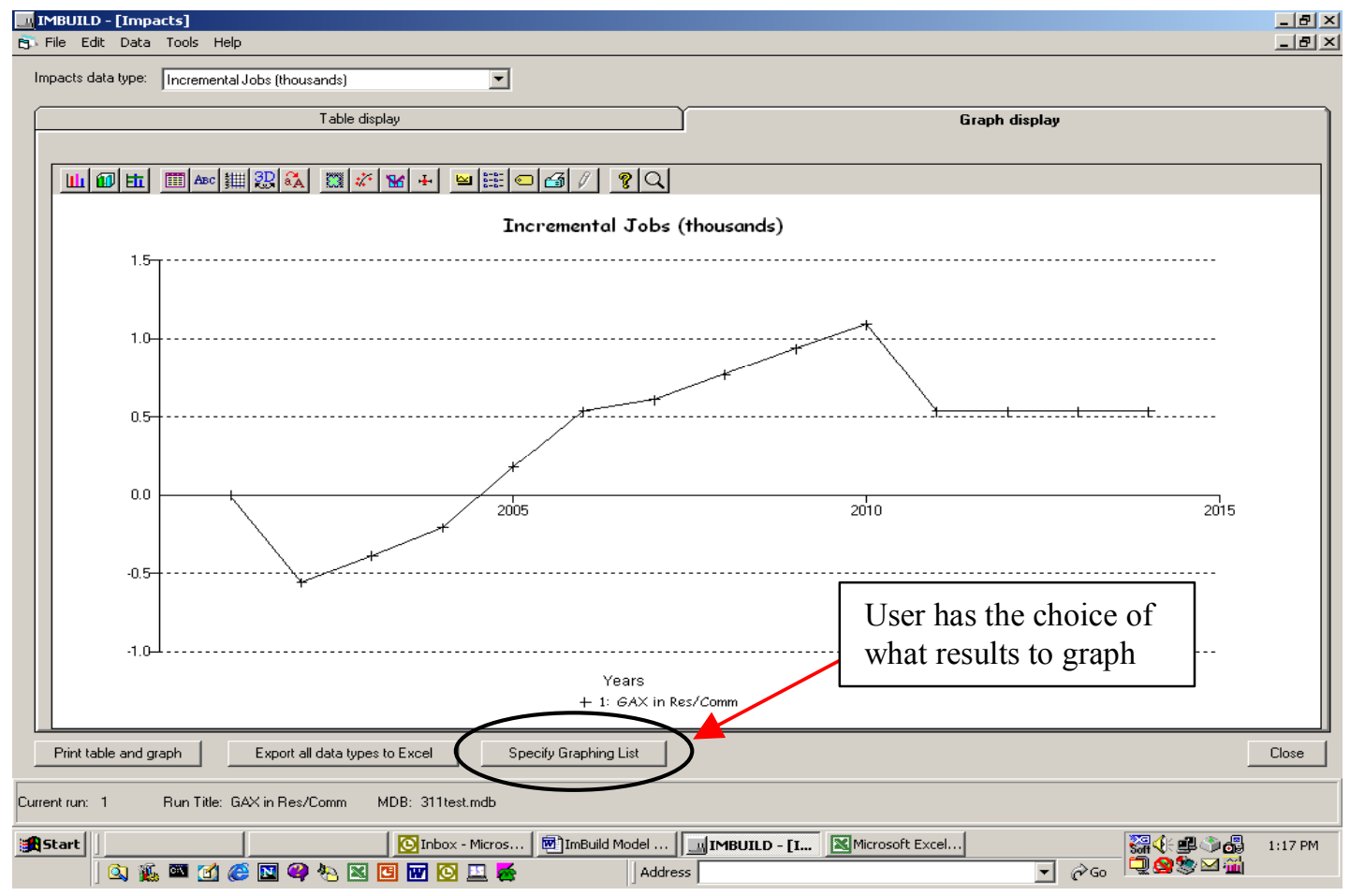

Figure 5.12. Report Manager Screens for Output (Graphical Display) 


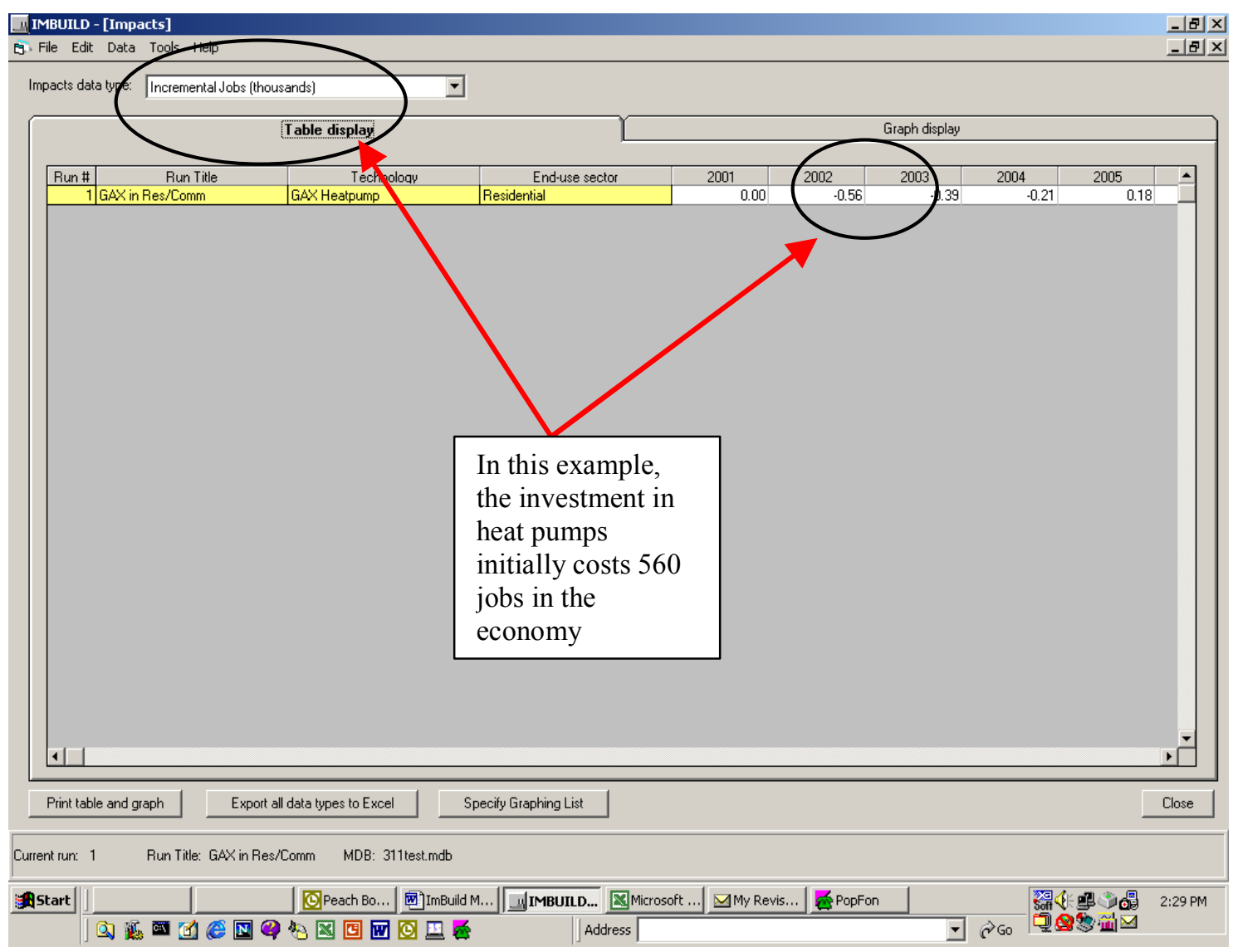

Figure 5.13. Report Manager Screens for Output (Table Display) 


\subsection{References}

Alliance to Save Energy, Council for an Energy-Efficient Economy, Natural Resources Defense Council, and Union of Concerned Scientists. 1991. America 's Energy Choices: Investing in a Strong Economy and a Clean Environment. Cambridge, Massachusetts: Union of Concerned Scientists.

Buchsbaum S, JW Benson, S Hildreth, SK Moody, and M Zylber. 1979. Jobs and Energy. NY: Council on Economic Priorities.

Energy Information Administration (EIA). 1996. Natural Gas 1996: Issues and Trends.

DOE/EIA-0560(96), Energy Information Administration, U.S. Department of Energy, Washington, D.C.

Energy Information Administration (EIA). 1997. Annual Energy Outlook 1998. DOE/EIA-0383(98).

Energy Information Administration, U.S. Department of Energy, Washington, D.C.

Geller H, J DeCicco, and S Laitner. 1992. Energy Efficiency and Job Creation: The Employment and Income Benefits from Investing in Energy Conserving Technologies. Washington, D.C.: The American Council for an Energy-Efficient Economy.

Jaccard M and D Sims. 1991. "Employment Impacts of Electricity Conservation: The Case of British Columbia. Energy Studies Review, 3(1):35-44.

Laitner S. 1992. “Missouri's Two-Percent Solution: Energy Efficiency for Economic Development and the Environment." Summary Report. Eugene, Oregon: Economic Research Associates.

Laitner S, S Bernow, and J DeCicco. 1998. "Employment and other macroeconomic effects of an innovation-led climate strategy for the United States," Energy Policy, 26(5):425-432.

Minnesota IMPLAN Group, Inc. 1997. IMPLAN Professional: Social Accounting and Impact Analysis Software. Minnesota IMPLAN Group, Inc., Stillwater, Minnesota.

Moscovitch E. 1994. "DSM in the Broader Economy: The Economic Impacts of Utility Efficiency Programs," The Electricity Journal, 7(4): 14-28.

Pacific Northwest National Laboratory (PNNL). 2001. FY2002 GPRA Metrics Inputs and Documentation. Pacific Northwest National Laboratory for U.S. Department of Energy, Office of Building Technology, State and Community Programs. Pacific Northwest National Laboratory, Richland, Washington.

Scott MJ, DJ Hostick, and DB Belzer. 1998. ImBuild: Impact of Building Energy Efficiency Programs. PNNL-11884, Pacific Northwest National Laboratory, Richland, Washington. 
Solow RM. 1994. "DSM: Not for Jobs, but on its Merits." The Electricity Journal, 7(4):80-81. 


\section{Appendix A}

\section{Base Cases for Building Energy Efficiency Technologies}

Table A.1. Heat Pump Water Heater Base Case

\begin{tabular}{|c|c|c|c|c|c|c|c|c|c|c|}
\hline \multirow[b]{2}{*}{ Base Case } & \multicolumn{10}{|c|}{ Heat Pump Water Heater } \\
\hline & 2003 & 2004 & 2005 & 2006 & 2007 & 2010 & 2015 & 2020 & 2025 & 2030 \\
\hline \multicolumn{11}{|c|}{ Installation Cost Increase (+) or Savings(-) Million \$ } \\
\hline & 190.74 & 193.29 & 195.23 & 198.23 & 123.17 & 126.57 & 0 & 0 & 0 & 0 \\
\hline \multicolumn{11}{|c|}{ Installation Cost Increase $(+)$ or Savings(-) Million \$ } \\
\hline & 0 & 0 & 0 & 0 & 0 & 0 & 0 & 0 & 0 & 0 \\
\hline \multicolumn{11}{|c|}{ Energy/Resource Cost Increase (+) or Savings (-) Million \$ } \\
\hline Residential -- Oil & 0 & 0 & 0 & 0 & 0 & 0 & 0 & 0 & 0 & 0 \\
\hline Residential -- Natural Gas & 0 & 0 & 0 & 0 & 0 & 0 & 0 & 0 & 0 & 0 \\
\hline Residential -- Electricity & 0 & -14.96 & -23.87 & -39.28 & -61.54 & -203.48 & -504.69 & -625.64 & -762.9 & -919.02 \\
\hline Residential -- Water & 0 & 0 & 0 & 0 & 0 & 0 & 0 & 0 & 0 & 0 \\
\hline Commercial -- Oil & 0 & 0 & 0 & 0 & 0 & 0 & 0 & 0 & 0 & 0 \\
\hline Commercial -- Natural Gas & 0 & 0 & 0 & 0 & 0 & 0 & 0 & 0 & 0 & 0 \\
\hline Commercial -- Electricity & 0 & 0 & 0 & 0 & 0 & 0 & 0 & 0 & 0 & 0 \\
\hline Commercial -- Water & 0 & 0 & 0 & 0 & 0 & 0 & 0 & 0 & 0 & 0 \\
\hline Industrial -- Oil & 0 & 0 & 0 & 0 & 0 & 0 & 0 & 0 & 0 & 0 \\
\hline Industrial -- Natural gas & 0 & 0 & 0 & 0 & 0 & 0 & 0 & 0 & 0 & 0 \\
\hline Industrial -- Electricity & 0 & 0 & 0 & 0 & 0 & 0 & 0 & 0 & 0 & 0 \\
\hline Industrial -- Water & 0 & 0 & 0 & 0 & 0 & 0 & 0 & 0 & 0 & 0 \\
\hline Transportation -- Oil & 0 & 0 & 0 & 0 & 0 & 0 & 0 & 0 & 0 & 0 \\
\hline $\begin{array}{l}\text { Transportation -- Natural } \\
\text { Gas }\end{array}$ & 0 & 0 & 0 & 0 & 0 & 0 & 0 & 0 & 0 & 0 \\
\hline Transportation -- Electricity & 0 & 0 & 0 & 0 & 0 & 0 & 0 & 0 & 0 & 0 \\
\hline Transportation -- Water & 0 & 0 & 0 & 0 & 0 & 0 & 0 & 0 & 0 & 0 \\
\hline \multicolumn{11}{|c|}{ O\&M Cost Increase (+) or Savings (-) (Million \$) } \\
\hline Residential & 0 & 0 & 0 & 0 & 0 & 0 & 0 & 0 & 0 & 0 \\
\hline Commercial & 0 & 0 & 0 & 0 & 0 & 0 & 0 & 0 & 0 & 0 \\
\hline Industrial & 0 & 0 & 0 & 0 & 0 & 0 & 0 & 0 & 0 & 0 \\
\hline Transportation & 0 & 0 & 0 & 0 & 0 & 0 & 0 & 0 & 0 & 0 \\
\hline \multicolumn{11}{|c|}{ Energy/Resource Units Saved (-) or Used (For System Investment) } \\
\hline Oil $\left(10^{12} \mathrm{Btu}\right)$ & 0 & 0 & 0 & 0 & 0 & 0 & 0 & 0 & 0 & 0 \\
\hline Natural Gas $\left(10^{12} \mathrm{Btu}\right)$ & 0 & 0 & 0 & 0 & 0 & 0 & 0 & 0 & 0 & 0 \\
\hline Electricity $\left(10^{12} \mathrm{Btu}\right)$ & 0 & -0.67 & -1.09 & -1.78 & -2.81 & -9.3 & -22.93 & -28.22 & -34.18 & -40.9 \\
\hline Water (10 $0^{9}$ Gallons $)$ & 0 & 0 & 0 & 0 & 0 & 0 & 0 & 0 & 0 & 0 \\
\hline
\end{tabular}


Table A.2. EPACT Standards Base Case

\begin{tabular}{|c|c|c|c|c|c|c|c|c|c|c|}
\hline \multirow[b]{2}{*}{ Base Case } & \multicolumn{10}{|c|}{ EPACT Standards } \\
\hline & 2003 & 2004 & 2005 & 2006 & 2007 & 2010 & 2015 & 2020 & 2025 & 2030 \\
\hline \multicolumn{11}{|c|}{ Installation Cost Increase (+) or Savings (-) Million \$ } \\
\hline & 0 & 0 & 0 & 0 & 0 & 0 & 0 & 0 & 0 & 0 \\
\hline \multicolumn{11}{|c|}{ Installation Cost Increase (+) or Savings (-) Million \$ } \\
\hline & 0 & 0 & 0 & 0 & 0 & 0 & 0 & 0 & 0 & 0 \\
\hline \multicolumn{11}{|c|}{ Energy/Resource Cost Increase (+) or Savings (-) Million \$ } \\
\hline Residential -- Oil & 0 & 0 & 0 & 0 & 0 & 0 & 0 & 0 & 0 & 0 \\
\hline $\begin{array}{l}\text { Residential -- Natural } \\
\text { gas }\end{array}$ & 0 & 0 & 0 & 0 & 0 & 0 & 0 & 0 & 0 & 0 \\
\hline \begin{tabular}{|l} 
Residential -- \\
Electricity
\end{tabular} & 0 & 0 & 0 & 0 & 0 & 0 & 0 & 0 & 0 & 0 \\
\hline Residential -- Water & 0 & 0 & 0 & 0 & 0 & 0 & 0 & 0 & 0 & 0 \\
\hline Commercial -- Oil & 0 & 0 & 0 & 0 & 0 & 0 & 0 & 0 & 0 & 0 \\
\hline $\begin{array}{l}\text { Commercial -- Natural } \\
\text { gas }\end{array}$ & 0 & 0 & 0 & 0 & 0 & -15.95 & -43.45 & -74.23 & -100.51 & -127.87 \\
\hline \begin{tabular}{|l} 
Commercial -- \\
Electricity
\end{tabular} & $\overline{0}$ & 0 & -48.95 & -95.35 & -145.36 & -535.95 & -1321.91 & -2152.66 & -2447.39 & -2752.04 \\
\hline Commercial -- Water & 0 & 0 & 0 & 0 & 0 & 0 & 0 & 0 & 0 & 0 \\
\hline Industrial -- Oil & 0 & 0 & 0 & 0 & 0 & 0 & 0 & 0 & 0 & 0 \\
\hline $\begin{array}{l}\text { Industrial -- Natural } \\
\text { gas }\end{array}$ & 0 & 0 & 0 & 0 & 0 & 0 & 0 & 0 & 0 & 0 \\
\hline Industrial -- Electricity & 0 & 0 & 0 & 0 & 0 & 0 & 0 & 0 & 0 & 0 \\
\hline Industrial -- Water & 0 & 0 & 0 & 0 & 0 & 0 & 0 & 0 & 0 & 0 \\
\hline Transportation -- Oil & 0 & 0 & 0 & 0 & 0 & 0 & 0 & 0 & 0 & 0 \\
\hline
\end{tabular}


Table A.2. (contd)

\begin{tabular}{|c|c|c|c|c|c|c|c|c|c|c|}
\hline \multirow[b]{2}{*}{ Base Case } & \multicolumn{10}{|c|}{ Heat Pump Water Heater } \\
\hline & 2003 & 2004 & 2005 & 2006 & 2007 & 2010 & 2015 & 2020 & 2025 & 2030 \\
\hline $\begin{array}{l}\text { Transportation -- } \\
\text { Natural gas }\end{array}$ & 0 & 0 & 0 & 0 & 0 & 0 & 0 & 0 & 0 & 0 \\
\hline $\begin{array}{l}\text { Transportation -- } \\
\text { Electricity }\end{array}$ & 0 & 0 & 0 & 0 & 0 & 0 & 0 & 0 & 0 & 0 \\
\hline $\begin{array}{l}\text { Transportation -- } \\
\text { Water }\end{array}$ & 0 & 0 & 0 & 0 & 0 & 0 & 0 & 0 & 0 & 0 \\
\hline \multicolumn{11}{|c|}{ O\&M Cost Increase (+) or Savings (-) (Million \$) } \\
\hline Residential & 0 & 0 & 0 & 0 & 0 & 0 & 0 & 0 & 0 & 0 \\
\hline Commercial & 0 & 0 & 0 & 0 & 0 & 0 & 0 & 0 & 0 & 0 \\
\hline Industrial & 0 & 0 & 0 & 0 & 0 & 0 & 0 & 0 & 0 & 0 \\
\hline Transportation & 0 & 0 & 0 & 0 & 0 & 0 & 0 & 0 & 0 & 0 \\
\hline \multicolumn{11}{|c|}{ Energy/Resource Units Saved (-) or Used (For System Investment) } \\
\hline Oil $\left(10^{12} \mathrm{Btu}\right)$ & 0 & 0 & 0 & 0 & 0 & 0 & 0 & 0 & 0 & 0 \\
\hline $\begin{array}{l}\text { Natural gas }\left(10^{12}\right. \\
\text { Btu) }\end{array}$ & 0 & 0 & 0 & 0 & 0 & -2.9 & -7.9 & -13 & -17.3 & -21.6 \\
\hline $\begin{array}{l}\text { Electricity }\left(10^{12}\right. \\
\text { Btu })\end{array}$ & 0 & 0 & -2.5 & -5 & -7.9 & -30.4 & -74.6 & -118.8 & -133.3 & -147.8 \\
\hline $\begin{array}{l}\text { Water }\left(10^{9}\right. \\
\text { Gallons })\end{array}$ & 0 & 0 & 0 & 0 & 0 & 0 & 0 & 0 & 0 & 0 \\
\hline
\end{tabular}


Table A.3. Residential Technology R\&D Base Case

\begin{tabular}{|c|c|c|c|c|c|c|c|c|c|c|}
\hline \multirow[b]{2}{*}{ Base Case } & \multicolumn{10}{|c|}{ Residential Technology Research and Development } \\
\hline & 2003 & 2004 & 2005 & 2006 & 2007 & 2010 & 2015 & 2020 & 2025 & 2030 \\
\hline \multicolumn{11}{|c|}{ Installation Cost Increase (+) or Savings(-) Million \$ } \\
\hline & 18.16 & 22.7 & 37.71 & 65.48 & 86.42 & 124.04 & 76.63 & 33.22 & 27.21 & 27.21 \\
\hline \multicolumn{11}{|c|}{ Installation Cost Increase (+) or Savings(-) Million \$ } \\
\hline & 0 & 0 & 0 & 0 & 0 & 0 & 0 & 0 & 0 & 0 \\
\hline \multicolumn{11}{|c|}{ Energy/Resource Cost Increase (+) or Savings (-) Million \$ } \\
\hline Residential -- Oil & -0.04 & -0.09 & -0.2 & -0.35 & -0.6 & -1.81 & -3.78 & -4.86 & -5.54 & -6.26 \\
\hline Residential -- Natural gas & -0.59 & -1.45 & -3.15 & -6.29 & -10.56 & -30.71 & -59.65 & -74.59 & -82.62 & -90.57 \\
\hline Residential -- Electricity & -0.61 & -1.5 & -2.92 & -6.06 & -10.45 & -31.35 & -67.61 & -89.58 & -99.68 & -109.78 \\
\hline Residential -- Water & 0 & 0 & 0 & 0 & 0 & 0 & 0 & 0 & 0 & 0 \\
\hline Commercial -- Oil & 0 & 0 & 0 & 0 & 0 & 0 & 0 & 0 & 0 & 0 \\
\hline Commercial -- Natural gas & 0 & 0 & 0 & 0 & 0 & 0 & 0 & 0 & 0 & 0 \\
\hline Commercial -- Electricity & 0 & 0 & 0 & 0 & 0 & 0 & 0 & 0 & 0 & 0 \\
\hline Commercial -- Water & 0 & 0 & 0 & 0 & 0 & 0 & 0 & 0 & 0 & 0 \\
\hline Industrial -- Oil & 0 & 0 & 0 & 0 & 0 & 0 & 0 & 0 & 0 & 0 \\
\hline Industrial -- Natural gas & 0 & 0 & 0 & 0 & 0 & 0 & 0 & 0 & 0 & 0 \\
\hline Industrial -- Electricity & 0 & 0 & 0 & 0 & 0 & 0 & 0 & 0 & 0 & 0 \\
\hline Industrial -- Water & 0 & 0 & 0 & 0 & 0 & 0 & 0 & 0 & 0 & 0 \\
\hline Transportation -- Oil & 0 & 0 & 0 & 0 & 0 & 0 & 0 & 0 & 0 & 0 \\
\hline $\begin{array}{l}\text { Transportation -- Natural } \\
\text { gas }\end{array}$ & 0 & 0 & 0 & 0 & 0 & 0 & 0 & 0 & 0 & 0 \\
\hline Transportation -- Electricity & 0 & 0 & 0 & 0 & 0 & 0 & 0 & 0 & 0 & 0 \\
\hline Transportation -- Water & 0 & 0 & 0 & 0 & 0 & 0 & 0 & 0 & 0 & 0 \\
\hline \multicolumn{11}{|c|}{ O\&M Cost Increase (+) or Savings(-) (Million \$) } \\
\hline Residential & 0 & 0 & 0 & 0 & 0 & 0 & 0 & 0 & 0 & 0 \\
\hline Commercial & 0 & 0 & 0 & 0 & 0 & 0 & 0 & 0 & 0 & 0 \\
\hline Industrial & 0 & 0 & 0 & 0 & 0 & 0 & 0 & 0 & 0 & 0 \\
\hline Transportation & 0 & 0 & 0 & 0 & 0 & 0 & 0 & 0 & 0 & 0 \\
\hline \multicolumn{11}{|c|}{ Energy/Resource units Saved (-) or Used (For System Investment) } \\
\hline Oil (10^12 Btu) & 0 & -0.01 & -0.03 & -0.05 & -0.08 & -0.24 & -0.48 & -0.61 & -0.67 & -0.74 \\
\hline Natural gas $\left(10^{\wedge} 12 \mathrm{Btu}\right)$ & -0.09 & -0.22 & -0.47 & -0.95 & -1.6 & -4.7 & -9.26 & -11.39 & -12.59 & -13.79 \\
\hline Electricity $\left(10^{\wedge} 12 \mathrm{Btu}\right)$ & -0.03 & -0.07 & -0.13 & -0.27 & -0.48 & -1.43 & -3.07 & -4.04 & -4.47 & -4.89 \\
\hline Water $\left(10^{\wedge} 9\right.$ Gallons $)$ & 0 & 0 & 0 & 0 & 0 & 0 & 0 & 0 & 0 & 0 \\
\hline
\end{tabular}




\section{Appendix B}

\section{Sectoral Detail}

Table B.1. Cross Reference Between ImBuild Sectors and 1992 U.S. Input-Output Table Sectors

\begin{tabular}{|c|c|c|c|}
\hline \multicolumn{4}{|c|}{$\begin{array}{c}\text { Correspondence Between IMBUILD II Sectors and } \\
\text { Benchmark } 1992 \text { Input-Output Table }\end{array}$} \\
\hline $\begin{array}{l}\text { IMBUILD } \\
\text { Sector \# }\end{array}$ & $\begin{array}{l}\text { IMBUILD } \\
\text { Title }\end{array}$ & $\begin{array}{l}\text { I/O 2-Digit } \\
\text { Category }\end{array}$ & $\begin{array}{l}\text { I/O Industry } \\
\text { Number }\end{array}$ \\
\hline 1 & Agriculture, Forestry and Fisheries & 01 through 04 & $010100-040002$ \\
\hline 2 & Mining except Nonmetallic minerals & $\begin{array}{l}05 \text { through } 08 \text {; part of } 09 \\
\text { plus } 10\end{array}$ & $050001-100000$ X $090001-090003$ \\
\hline 3 & Nonmetallic mineral mining & Part of 09 & $090001-090003$ \\
\hline 4 & Residential Construction & Parts of 11 and 12 & $\begin{array}{l}110101,110102,110105 \\
110108,120101\end{array}$ \\
\hline 5 & Commercial Construction & Parts of 11 and 12 & 110800,120300 \\
\hline 6 & Other Construction & Parts of 11 and 12 & $\begin{array}{l}110400,110501,110601,110602 \\
110603,110900,120214,120215\end{array}$ \\
\hline 7 & Food and Tobacco Products & 14 and 15 & $140101-150200$ \\
\hline 8 & Fabrics and Yarn & 16 & $160100-160400$ \\
\hline 9 & Other Textiles & 17 & $170100-171100$ \\
\hline 10 & Apparel & 18 & $180101-180400$ \\
\hline 11 & Fabricated Textile Products & 19 & $190100-190306$ \\
\hline 12 & Other Wood Products & Part of 20,21 & $\begin{array}{l}200100-200400,200502-200701 \\
200800-210000\end{array}$ \\
\hline 13 & Millwork & Part of 20 & 200501 \\
\hline 14 & Fabricated Buildings & Part of 20 & 200702,200703 \\
\hline 15 & Furniture and Fixtures & $22+23$ & $220101-230700$ \\
\hline 16 & $\begin{array}{l}\text { Paper and Products except } \\
\text { Containers }\end{array}$ & 24 & $240100-240800$ \\
\hline 17 & Containers and Boxes & 25 & 250000 \\
\hline 18 & Newspapers and Other Printing & $26 \mathrm{~A}+26 \mathrm{~B}$ & $260100-260806$ \\
\hline 19 & Industrial Chemicals & $27 \mathrm{~A}$ & $270100-270406$ \\
\hline 20 & Agricultural Chemicals & $27 \mathrm{~B}$ & $270201-270300$ \\
\hline 21 & Plastics & Part of 28 & 280100 \\
\hline 22 & Synthetic Materials & Part of 28 & $280200-280400$ \\
\hline 23 & Drugs and Cleaning & $29 A+29 B$ & $290100-290300$ \\
\hline 24 & Paints and Allied Products & 30 & 300000 \\
\hline 25 & Petroleum Refining & Part of 31 & 310101 \\
\hline 26 & Other Petrol Products & Part of 31 & $310102-310300$ \\
\hline 27 & Rubber and Plastic Products & 32 & $320100-320600$ \\
\hline 28 & Foot-ware and Leather & $33+34$ & $330001-340305$ \\
\hline
\end{tabular}

B. 1 
Table B.1. (contd)

\begin{tabular}{|c|c|c|c|}
\hline \multicolumn{4}{|c|}{$\begin{array}{c}\text { Correspondence Between IMBUILD II Sectors and } \\
\text { Benchmark } 1992 \text { Input-Output Table }\end{array}$} \\
\hline $\begin{array}{l}\text { IMBUILD } \\
\text { Sector \# }\end{array}$ & $\begin{array}{l}\text { IMBUILD } \\
\text { Title }\end{array}$ & $\begin{array}{l}\text { I/O 2-Digit } \\
\text { Category }\end{array}$ & $\begin{array}{l}\text { I/O Industry } \\
\text { Number }\end{array}$ \\
\hline 29 & Other Glass Products & Part of 35 & 350100 \\
\hline 30 & Glass Containers & Part of 35 & 350200 \\
\hline 31 & Cement & Part of 36 & 360100 \\
\hline 32 & Lime and Gypsum & Part of 36 & $361300-361400$ \\
\hline 33 & Mineral Wool & Part of 36 & 362000 \\
\hline 34 & Other Nonmetallic Minerals & Part of 36 & $\begin{array}{l}360200-361200,361500-361900, \\
362100,362200\end{array}$ \\
\hline 35 & Iron and Steel & 37 & $370101-370402$ \\
\hline 36 & Aluminum & Part of 38 & $380400,380800,381100$ \\
\hline 37 & Other Nonferrous Metals & Part of 38 & All of 380000 except above \\
\hline 38 & Metal Containers & 39 & 390100,390200 \\
\hline 39 & Heating Equipment & Part of 40 & 400300 \\
\hline 40 & Structural metal & Part of 40 & 400400 \\
\hline 41 & Metal Doors, etc. & Part of 40 & 400500 \\
\hline 42 & Sheet Metal Work & Part of 40 & 400700 \\
\hline 43 & Other Structural Metal Products & Part of 40 & $400100-400200,400800-40902$ \\
\hline 44 & Screw Machine Products & 41 & $410100-410203$ \\
\hline 45 & Other Fabricated Metal Products & 42 & $420100-421100$ \\
\hline 46 & Engines and Turbines & 43 & $430100-430200$ \\
\hline 47 & Machinery \& Equipment & $44-50$ & $440100-500400$ \\
\hline 48 & Computer and Office Equipment & 51 & $510102-510400$ \\
\hline 49 & Commercial Laundry Equipment & Part of 52 & 5202000 \\
\hline 50 & $\begin{array}{l}\text { Commercial Refrigeration and } \\
\text { Heating Equipment }\end{array}$ & Part of 52 & 520300 \\
\hline 51 & Other Service Equipment & Part of 52 & $520100,520400,520500$ \\
\hline 52 & Power Equipment & Part of 53 & 530200 \\
\hline 53 & Motors and Generators & Part of 53 & 530400 \\
\hline 54 & Relays and Industrial Controls & Part of 53 & 530500 \\
\hline 55 & Other Electrical Equipment & Part of 53 & $530300,530700,530800$ \\
\hline 56 & Household Cooking & Part of 54 & 540100 \\
\hline 57 & HH Refrigeration and Freezers & Part of 54 & 540200 \\
\hline 58 & HH Laundry & Part of 54 & 540300 \\
\hline 59 & Electric House-wares and Fans & Part of 54 & 540400 \\
\hline 60 & HH Vacuum Cleaners & Part of 54 & 540500 \\
\hline 61 & HH Appliances, n.e.c. & Part of 54 & 540700 \\
\hline 62 & Lighting Bulbs and Tubes & Part of 55 & 550100 \\
\hline
\end{tabular}


Table B.1. (contd)

\begin{tabular}{|c|c|c|c|}
\hline \multicolumn{4}{|c|}{$\begin{array}{l}\text { Correspondence Between IMBUILD II Sectors and } \\
\text { Benchmark } 1992 \text { Input-Output Table }\end{array}$} \\
\hline $\begin{array}{l}\text { IMBUILD } \\
\text { Sector \# }\end{array}$ & $\begin{array}{l}\text { IMBUILD } \\
\text { Title }\end{array}$ & $\begin{array}{l}\text { I/O 2-Digit } \\
\text { Category }\end{array}$ & $\begin{array}{l}\text { I/O Industry } \\
\text { Number }\end{array}$ \\
\hline 63 & Other Lighting and Wiring & Part of 55 & 550200,550300 \\
\hline 64 & Communications Equip & 56 & $560100-560500$ \\
\hline 65 & Electronic Components & 57 & $570100-570300$ \\
\hline 66 & Misc. Electric Supplies & 58 & $580100-580700$ \\
\hline 67 & Motor Vehicles & $59 \mathrm{~A}$ & 590301 \\
\hline 68 & Bodies, Trailers \& Parts & $59 \mathrm{~B}$ & $590100,590200,500302$ \\
\hline 69 & Aircraft and Parts & 60 & $600100-600400$ \\
\hline 70 & Other Transport Equipment & 61 & $610100-610700$ \\
\hline 71 & Measuring and Control Devices & Part of 62 & $620200,620300,621100$ \\
\hline 72 & Other Manufacturing & 13, Part of 62,6364 & $\begin{array}{l}130100-130700 ; \text { All of } 620000 \\
\text { except above; } 630200-641200\end{array}$ \\
\hline 73 & Rail Transport & $65 \mathrm{~A}$ & 650100,650200 \\
\hline 74 & Motor Freight Transport & $65 \mathrm{~B}$ & 650301,650302 \\
\hline 75 & Water Transport & $65 \mathrm{C}$ & 650400 \\
\hline 76 & Air Transport & $65 \mathrm{D}$ & 650500 \\
\hline 77 & Pipelines & $65 \mathrm{E}$ & $650600-650702,680201$ \\
\hline 78 & Communications & $66+67$ & $660100-670000$ \\
\hline 79 & Electric Utilities & $68 \mathrm{~A}$ & $680100,780200,790200$ \\
\hline 80 & Gas Utilities & $68 \mathrm{~B}$ & 680202 \\
\hline 81 & Water Utilities & $68 \mathrm{C}$ & 680301,680302 \\
\hline 82 & Wholesale and Retail Trade & 69 & 690100,690200 \\
\hline 83 & Finance and Insurance & 70 & $700100-700500$ \\
\hline 84 & Owner Occupied Dwellings & $71 \mathrm{~A}$ & 710100 \\
\hline 85 & Real Estate and Royalties & $71 \mathrm{~B}$ & 710201,710202 \\
\hline 86 & Hotels and other lodging & $72 \mathrm{~A}$ & 720101 \\
\hline 87 & Personal and Repair Svc & $72 \mathrm{~B}$ & $720201-720300$ \\
\hline 88 & Other Services & 73 & $730101-730303$ \\
\hline 89 & Eating and Drinking Places & 74 & 740000 \\
\hline 90 & Auto Repair and Svc & 75 & $750001-750003$ \\
\hline 91 & Amusements & 76 & $760101-760205$ \\
\hline 92 & Health Services & $77 \mathrm{~A}$ & $770100-770305$ \\
\hline 93 & Education and Other Svc & $77 \mathrm{~B}$ & $770401-770900$ \\
\hline 94 & Federal Enterprises & Part of 78 & 780100,780500 \\
\hline 95 & S\&L Enterprises & Part of 79 & 790100,790300 \\
\hline 96 & Non-comparable Imports & 80 & 800000 \\
\hline 97 & Miscellany & $81,83,84,85$ & $\begin{array}{l}810001,810002,830000,840000, \\
850000\end{array}$ \\
\hline 98 & General Govt. Industry & 82 & 820000 \\
\hline
\end{tabular}


Table B.2. Detailed 1992 Input-Output Sectors

\begin{tabular}{|c|c|}
\hline $\begin{array}{c}\text { Sector } \\
\text { Number }\end{array}$ & 1992 Input-Output Sector Description \\
\hline \multicolumn{2}{|c|}{01 Livestock and livestock products } \\
\hline 010100 & Dairy farm products \\
\hline 010200 & Poultry and eggs \\
\hline 010301 & Meat animals \\
\hline 010302 & Miscellaneous livestock \\
\hline \multicolumn{2}{|c|}{ 02 Other agricultural products } \\
\hline 020100 & Cotton \\
\hline 020201 & Food grains \\
\hline 020202 & Feed grains \\
\hline 020203 & Grass seeds \\
\hline 020300 & Tobacco \\
\hline 020401 & Fruits \\
\hline 020402 & Tree nuts \\
\hline 020501 & Vegetables \\
\hline 020502 & Sugar crops \\
\hline 020503 & Miscellaneous crops \\
\hline 020600 & Oil bearing crops \\
\hline 020701 & Forest products \\
\hline 020702 & Greenhouse and nursery products \\
\hline \multicolumn{2}{|c|}{03 Forestry and fishery products } \\
\hline 030001 & Forestry products \\
\hline 030002 & Commercial fishing \\
\hline \multicolumn{2}{|c|}{ 04 Agricultural, forestry, and fishery services } \\
\hline 040001 & Agricultural, forestry, and fishery services \\
\hline 040002 & Landscape and horticultural services \\
\hline \multicolumn{2}{|c|}{ 05+06 Metallic ores mining } \\
\hline 050001 & Iron and ferroalloy ores, and miscellaneous metal ores, n.e.c. \\
\hline 060100 & Copper ore \\
\hline 060200 & Nonferrous metal ores, except copper \\
\hline \multicolumn{2}{|c|}{ 07 Coal mining } \\
\hline 070000 & Coal \\
\hline \multicolumn{2}{|c|}{08 Crude petroleum and natural gas } \\
\hline 080001 & Crude petroleum and natural gas \\
\hline
\end{tabular}


Table B.2. (contd)

\begin{tabular}{|c|c|}
\hline $\begin{array}{c}\text { Sector } \\
\text { Number }\end{array}$ & 1992 Input-Output Sector Description \\
\hline \multicolumn{2}{|c|}{ 09+10 Nonmetallic minerals mining } \\
\hline 090001 & Dimension, crushed and broken stone \\
\hline 090002 & Sand and gravel \\
\hline 090003 & Clay, ceramic, and refractory minerals \\
\hline 090004 & Nonmetallic mineral services and miscellaneous \\
\hline 100000 & Chemical and fertilizer minerals \\
\hline \multicolumn{2}{|c|}{11 New construction } \\
\hline 110101 & New residential 1 unit structures, nonfarm \\
\hline 110102 & New residential 2-4 unit structures, nonfarm \\
\hline 110105 & New residential additions and alterations, nonfarm \\
\hline 110108 & New residential garden and high-rise apartments construction \\
\hline 110400 & New highways, bridges, and other horizontal construction \\
\hline 110501 & New farm residential construction \\
\hline 110601 & Petroleum and natural gas well drilling \\
\hline 110602 & Petroleum, natural gas, and solid mineral exploration \\
\hline 110603 & Access structures for solid mineral development \\
\hline 110800 & New office, industrial and commercial buildings construction \\
\hline 110900 & Other new construction \\
\hline \multicolumn{2}{|c|}{12 Maintenance and repair construction } \\
\hline 120101 & Maintenance and repair of farm and nonfarm residential structures \\
\hline 120214 & Maintenance and repair of highways \& streets \\
\hline 120215 & Maintenance and repair of petroleum and natural gas wells \\
\hline 120300 & Other repair and maintenance construction \\
\hline \multicolumn{2}{|c|}{13 Ordnance and accessories } \\
\hline 130100 & Guided missiles and space vehicles \\
\hline 130200 & Ammunition, except for small arms, n.e.c. \\
\hline 130300 & Tanks and tank components \\
\hline 130500 & Small arms \\
\hline 130600 & Small arms ammunition \\
\hline 130700 & Ordnance and accessories, n.e.c. \\
\hline
\end{tabular}


Table B.2. (contd)

\begin{tabular}{|c|c|}
\hline $\begin{array}{c}\text { Sector } \\
\text { Number }\end{array}$ & 1992 Input-Output Sector Description \\
\hline \multicolumn{2}{|c|}{14 Food and kindred products } \\
\hline 140101 & Meat packing plants \\
\hline 140102 & Sausages and other prepared meat products \\
\hline 140105 & Poultry slaughtering and processing \\
\hline 140200 & Creamery butter \\
\hline 140300 & Natural, processed, and imitation cheese \\
\hline 140400 & Dry, condensed, and evaporated dairy products \\
\hline 140500 & Ice cream and frozen desserts \\
\hline 140600 & Fluid milk \\
\hline 140700 & Canned and cured fish and seafoods \\
\hline 140800 & Canned specialties \\
\hline 140900 & Canned fruits, vegetables, preserves, jams, and jellies \\
\hline 141000 & Dehydrated fruits, vegetables, and soups \\
\hline 141100 & Pickles, sauces, and salad dressings \\
\hline 141200 & Prepared fresh or frozen fish and seafoods \\
\hline 141301 & Frozen fruits, fruit juices, and vegetables \\
\hline 141302 & Frozen specialties, n.e.c. \\
\hline 141401 & Flour and other grain mill products \\
\hline 141402 & Cereal breakfast foods \\
\hline 141403 & Prepared flour mixes and doughs \\
\hline 141501 & Dog and cat food \\
\hline 141502 & Prepared feeds, n.e.c. \\
\hline 141600 & Rice milling \\
\hline 141700 & Wet corn milling \\
\hline 141801 & Bread, cake, and related products \\
\hline 141802 & Cookies and crackers \\
\hline 141803 & Frozen bakery products, except bread \\
\hline 141900 & Sugar \\
\hline 142002 & Chocolate and cocoa products \\
\hline 142004 & Salted and roasted nuts and seeds \\
\hline 142005 & Candy and other confectionery products \\
\hline 142101 & Malt beverages \\
\hline 142102 & Malt \\
\hline 142103 & Wines, brandy, and brandy spirits \\
\hline
\end{tabular}


Table B.2. (contd)

\begin{tabular}{|c|c|}
\hline $\begin{array}{c}\text { Sector } \\
\text { Number }\end{array}$ & 1992 Input-Output Sector Description \\
\hline 142104 & Distilled and blended liquors \\
\hline 142200 & Bottled and canned soft drinks \\
\hline 142300 & Flavoring extracts and flavoring syrups, n.e.c. \\
\hline 142400 & Cottonseed oil mills \\
\hline 142500 & Soybean oil mills \\
\hline 142600 & Vegetable oil mills, n.e.c. \\
\hline 142700 & Animal and marine fats and oils \\
\hline 142800 & Roasted coffee \\
\hline 142900 & Edible fats and oils, n.e.c. \\
\hline 143000 & Manufactured ice \\
\hline 143100 & Macaroni, spaghetti, vermicelli, and noodles \\
\hline 143201 & Potato chips and similar snacks \\
\hline 143202 & Food preparations, n.e.c. \\
\hline \multicolumn{2}{|c|}{15 Tobacco products } \\
\hline 150101 & Cigarettes \\
\hline 150102 & Cigars \\
\hline 150103 & Chewing and smoking tobacco and snuff \\
\hline 150200 & Tobacco stemming and redrying \\
\hline \multicolumn{2}{|c|}{16 Broad and narrow fabrics, yarn and thread mills } \\
\hline 160100 & Broadwoven fabric mills and fabric finishing plants \\
\hline 160200 & Narrow fabric mills \\
\hline 160300 & Yarn mills and finishing of textiles, n.e.c. \\
\hline 160400 & Thread mills \\
\hline \multicolumn{2}{|c|}{17 Miscellaneous textile goods and floor coverings } \\
\hline 170100 & Carpets and rugs \\
\hline 170600 & Coated fabrics, not rubberized \\
\hline 170700 & Tire cord and fabrics \\
\hline 170900 & Cordage and twine \\
\hline 171001 & Nonwoven fabrics \\
\hline 171100 & Textile goods, n.e.c. \\
\hline
\end{tabular}


Table B.2. (contd)

\begin{tabular}{|c|c|}
\hline $\begin{array}{c}\text { Sector } \\
\text { Number }\end{array}$ & 1992 Input-Output Sector Description \\
\hline \multicolumn{2}{|l|}{18 Apparel } \\
\hline 180101 & Women's hosiery, except socks \\
\hline 180102 & Hosiery, n.e.c. \\
\hline 180201 & Knit outerwear mills \\
\hline 180202 & Knit underwear and nightwear mills \\
\hline 180203 & Knitting mills, n.e.c. \\
\hline 180300 & Knit fabric mills \\
\hline 180400 & Apparel made from purchased materials \\
\hline \multicolumn{2}{|c|}{19 Miscellaneous fabricated textile products } \\
\hline 190100 & Curtains and draperies \\
\hline 190200 & Housefurnishings, n.e.c. \\
\hline 190301 & Textile bags \\
\hline 190302 & Canvas and related products \\
\hline 190303 & Pleating and stitching \\
\hline 190304 & Automotive and apparel trimmings \\
\hline 190305 & Schiffli machine embroideries \\
\hline 190306 & Fabricated textile products, n.e.c. \\
\hline \multicolumn{2}{|l|}{$\begin{array}{l}20+21 \\
\text { Lumber and } \\
\text { wood } \\
\text { products }\end{array}$} \\
\hline 200100 & Logging \\
\hline 200200 & Sawmills and planing mills, general \\
\hline 200300 & Hardwood dimension and flooring mills \\
\hline 200400 & Special product sawmills, n.e.c. \\
\hline 200501 & Millwork \\
\hline 200502 & Wood kitchen cabinets \\
\hline 200600 & Veneer and plywood \\
\hline 200701 & Structural wood members, n.e.c. \\
\hline 200702 & Prefabricated wood buildings and components \\
\hline 200703 & Mobile homes \\
\hline 200800 & Wood preserving \\
\hline 200901 & Wood pallets and skids \\
\hline
\end{tabular}


Table B.2. (contd)

\begin{tabular}{|c|c|}
\hline $\begin{array}{c}\text { Sector } \\
\text { Number }\end{array}$ & 1992 Input-Output Sector Description \\
\hline 200903 & Wood products, n.e.c. \\
\hline 200904 & Reconstituted wood products \\
\hline 210000 & Wood containers, n.e.c. \\
\hline \multicolumn{2}{|c|}{$22+23$ Furniture and fixtures } \\
\hline 220101 & Wood household furniture, except upholstered \\
\hline 220102 & Household furniture, n.e.c. \\
\hline 220103 & Wood television and radio cabinets \\
\hline 220200 & Upholstered household furniture \\
\hline 220300 & Metal household furniture \\
\hline 220400 & Mattresses and bedsprings \\
\hline 230100 & Wood office furniture \\
\hline 230200 & Office furniture, except wood \\
\hline 230300 & Public building and related furniture \\
\hline 230400 & Wood partitions and fixtures \\
\hline 230500 & Partitions and fixtures, except wood \\
\hline 230600 & Drapery hardware and window blinds and shades \\
\hline 230700 & Furniture and fixtures, n.e.c. \\
\hline \multicolumn{2}{|c|}{24 Paper and allied products, except containers } \\
\hline 240100 & Pulp mills \\
\hline 240400 & Envelopes \\
\hline 240500 & Sanitary paper products \\
\hline 240701 & Paper coating and glazing \\
\hline 240702 & Bags, except textile \\
\hline 240703 & Die-cut paper and paperboard and cardboard \\
\hline 240705 & Stationery, tablets, and related products \\
\hline 240706 & Converted paper products, n.e.c. \\
\hline 240800 & Paper and paperboard mills \\
\hline \multicolumn{2}{|c|}{25 Paperboard containers and boxes } \\
\hline 250000 & Paperboard containers and boxes \\
\hline \multicolumn{2}{|c|}{ 26A Newspapers and periodicals } \\
\hline 260100 & Newspapers \\
\hline 260200 & Periodicals \\
\hline
\end{tabular}


Table B.2. (contd)

\begin{tabular}{|c|c|}
\hline $\begin{array}{c}\text { Sector } \\
\text { Number }\end{array}$ & 1992 Input-Output Sector Description \\
\hline \multicolumn{2}{|c|}{ 26B Other printing and publishing } \\
\hline 260301 & Book publishing \\
\hline 260302 & Book printing \\
\hline 260400 & Miscellaneous publishing \\
\hline 260501 & Commercial printing \\
\hline 260601 & Manifold business forms \\
\hline 260602 & Blankbooks, looseleaf binders and devices \\
\hline 260700 & Greeting cards \\
\hline 260802 & Bookbinding and related work \\
\hline 260803 & Typesetting \\
\hline 260806 & Platemaking and related services \\
\hline \multicolumn{2}{|c|}{ 27A Industrial and other chemicals } \\
\hline 270100 & Industrial inorganic and organic chemicals \\
\hline 270401 & Gum and wood chemicals \\
\hline 270402 & Adhesives and sealants \\
\hline 270403 & Explosives \\
\hline 270404 & Printing ink \\
\hline 270405 & Carbon black \\
\hline 270406 & Chemicals and chemical preparations, n.e.c. \\
\hline \multicolumn{2}{|c|}{ 27B Agricultural fertilizers and chemicals } \\
\hline 270201 & Nitrogenous and phosphatic fertilizers \\
\hline 270202 & Fertilizers, mixing only \\
\hline 270300 & Pesticides and agricultural chemicals, n.e.c. \\
\hline \multicolumn{2}{|c|}{28 Plastics and synthetic materials } \\
\hline 280100 & Plastics materials and resins \\
\hline 280200 & Synthetic rubber \\
\hline 280300 & Cellulosic manmade fibers \\
\hline 280400 & Manmade organic fibers, except cellulosic \\
\hline \multicolumn{2}{|l|}{ 29A Drugs } \\
\hline 290100 & Drugs \\
\hline
\end{tabular}


Table B.2. (contd)

\begin{tabular}{|c|c|}
\hline $\begin{array}{c}\text { Sector } \\
\text { Number }\end{array}$ & 1992 Input-Output Sector Description \\
\hline \multicolumn{2}{|c|}{ 29B Cleaning and toilet preparations } \\
\hline 290201 & Soap and other detergents \\
\hline 290202 & Polishes and sanitation goods \\
\hline 290203 & Surface active agents \\
\hline 290300 & Toilet preparations \\
\hline \multicolumn{2}{|c|}{30 Paints and allied products } \\
\hline 300000 & Paints and allied products \\
\hline \multicolumn{2}{|c|}{31 Petroleum refining and related products } \\
\hline 310101 & Petroleum refining \\
\hline 310102 & Lubricating oils and greases \\
\hline 310103 & Products of petroleum and coal, n.e.c. \\
\hline 310200 & Asphalt paving mixtures and blocks \\
\hline 310300 & Asphalt felts and coatings \\
\hline \multicolumn{2}{|c|}{32 Rubber and miscellaneous plastics products } \\
\hline 320100 & Tires and inner tubes \\
\hline 320200 & Rubber and plastics footwear \\
\hline 320300 & Fabricated rubber products, n.e.c. \\
\hline 320400 & Miscellaneous plastics products, n.e.c. \\
\hline 320500 & Rubber and plastics hose and belting \\
\hline 320600 & Gaskets, packing, and sealing devices \\
\hline \multicolumn{2}{|c|}{ 33+34 Footwear, leather, and leather products } \\
\hline 330001 & Leather tanning and finishing \\
\hline 340100 & Boot and shoe cut stock and findings \\
\hline 340201 & Shoes, except rubber \\
\hline 340202 & House slippers \\
\hline 340301 & Leather gloves and mittens \\
\hline 340302 & Luggage \\
\hline 340303 & Women's handbags and purses \\
\hline 340304 & Personal leather goods, n.e.c. \\
\hline 340305 & Leather goods, n.e.c. \\
\hline \multicolumn{2}{|l|}{$\begin{array}{l}\text { 35 Glass } \\
\text { and glass } \\
\text { products }\end{array}$} \\
\hline 350100 & Glass and glass products, except containers \\
\hline 350200 & Glass containers \\
\hline
\end{tabular}

B. 11 
Table B.2. (contd)

\begin{tabular}{|c|c|}
\hline $\begin{array}{c}\text { Sector } \\
\text { Number }\end{array}$ & 1992 Input-Output Sector Description \\
\hline $\begin{array}{l}\text { 36 Stone } \\
\text { and clay } \\
\text { products }\end{array}$ & \\
\hline 360100 & Cement, hydraulic \\
\hline 360200 & Brick and structural clay tile \\
\hline 360300 & Ceramic wall and floor tile \\
\hline 360400 & Clay refractories \\
\hline 360500 & Structural clay products, n.e.c. \\
\hline 360600 & Vitreous china plumbing fixtures \\
\hline 360701 & Vitreous china table and kitchenware \\
\hline 360702 & Fine earthenware table and kitchenware \\
\hline 360800 & Porcelain electrical supplies \\
\hline 360900 & Pottery products, n.e.c. \\
\hline 361000 & Concrete block and brick \\
\hline 361100 & Concrete products, except block and brick \\
\hline 361200 & Ready-mixed concrete \\
\hline 361300 & Lime \\
\hline 361400 & Gypsum products \\
\hline 361500 & Cut stone and stone products \\
\hline 361600 & Abrasive products \\
\hline 361700 & Asbestos products \\
\hline 361900 & Minerals, ground or treated \\
\hline 362000 & Mineral wool \\
\hline 362100 & Nonclay refractories \\
\hline 362200 & Nonmetallic mineral products, n.e.c. \\
\hline \multicolumn{2}{|c|}{37 Primary iron and steel manufacturing } \\
\hline 370101 & Blast furnaces and steel mills \\
\hline 370102 & Electrometallurgical products, except steel \\
\hline 370103 & Steel wiredrawing and steel nails and spikes \\
\hline 370104 & Cold-rolled steel sheet, strip, and bars \\
\hline 370105 & Steel pipe and tubes \\
\hline 370200 & Iron and steel foundries \\
\hline 370300 & Iron and steel forgings \\
\hline 370401 & Metal heat treating \\
\hline 370402 & Primary metal products, n.e.c. \\
\hline
\end{tabular}

B. 12 
Table B.2. (contd)

\begin{tabular}{|c|c|}
\hline $\begin{array}{c}\text { Sector } \\
\text { Number }\end{array}$ & 1992 Input-Output Sector Description \\
\hline \multicolumn{2}{|c|}{38 Primary nonferrous metals manufacturing } \\
\hline 380100 & Primary smelting and refining of copper \\
\hline 380400 & Primary aluminum \\
\hline 380501 & Primary nonferrous metals, n.e.c. \\
\hline 380600 & Secondary nonferrous metals \\
\hline 380700 & Rolling, drawing, and extruding of copper \\
\hline 380800 & Aluminum rolling and drawing \\
\hline 380900 & Nonferrous rolling and drawing, n.e.c. \\
\hline 381000 & Nonferrous wiredrawing and insulating \\
\hline 381100 & Aluminum castings \\
\hline 381200 & Copper foundries \\
\hline 381300 & Nonferrous castings, n.e.c. \\
\hline 381400 & Nonferrous forgings \\
\hline \multicolumn{2}{|c|}{39 Metal containers } \\
\hline 390100 & Metal cans \\
\hline 390200 & Metal shipping barrels, drums, kegs, and pails \\
\hline \multicolumn{2}{|c|}{40 Heating, plumbing, and fabricated structural metal products } \\
\hline 400100 & Enameled iron and metal sanitary ware \\
\hline 400200 & Plumbing fixture fittings and trim \\
\hline 400300 & Heating equipment, except electric and warm air furnaces \\
\hline 400400 & Fabricated structural metal \\
\hline 400500 & Metal doors, sash, frames, molding, and trim \\
\hline 400600 & Fabricated plate work (boiler shops) \\
\hline 400700 & Sheet metal work \\
\hline 400800 & Architectural and ornamental metal work \\
\hline 400901 & Prefabricated metal buildings and components \\
\hline 400902 & Miscellaneous structural metal work \\
\hline \multicolumn{2}{|c|}{41 Screw machine products and stampings } \\
\hline 410100 & Screw machine products, bolts, etc. \\
\hline 410201 & Automotive stampings \\
\hline 410202 & Crowns and closures \\
\hline 410203 & Metal stampings, n.e.c. \\
\hline
\end{tabular}


Table B.2. (contd)

\begin{tabular}{|c|c|}
\hline $\begin{array}{c}\text { Sector } \\
\text { Number }\end{array}$ & 1992 Input-Output Sector Description \\
\hline \multicolumn{2}{|c|}{42 Other fabricated metal products } \\
\hline 420100 & Cutlery \\
\hline 420201 & Hand and edge tools, except machine tools and handsaws \\
\hline 420202 & Saw blades and handsaws \\
\hline 420300 & Hardware, n.e.c. \\
\hline 420401 & Plating and polishing \\
\hline 420402 & Coating, engraving, and allied services, n.e.c. \\
\hline 420500 & Miscellaneous fabricated wire products \\
\hline 420700 & Steel springs, except wire \\
\hline 420800 & Pipe, valves, and pipe fittings \\
\hline 421000 & Metal foil and leaf \\
\hline 421100 & Fabricated metal products, n.e.c. \\
\hline \multicolumn{2}{|c|}{43 Engines and turbines } \\
\hline 430100 & Turbines and turbine generator sets \\
\hline 430200 & Internal combustion engines, n.e.c. \\
\hline \multicolumn{2}{|c|}{ 44+45 Farm, construction, and mining machinery } \\
\hline 440001 & Farm machinery and equipment \\
\hline 440002 & Lawn and garden equipment \\
\hline 450100 & Construction machinery and equipment \\
\hline 450200 & Mining machinery, except oil field \\
\hline 450300 & Oil and gas field machinery and equipment \\
\hline \multicolumn{2}{|c|}{46 Materials handling machinery and equipment } \\
\hline 460100 & Elevators and moving stairways \\
\hline 460200 & Conveyors and conveying equipment \\
\hline 460300 & Hoists, cranes, and monorails \\
\hline 460400 & Industrial trucks and tractors \\
\hline \multicolumn{2}{|c|}{47 Metalworking machinery and equipment } \\
\hline 470100 & Machine tools, metal cutting types \\
\hline 470200 & Machine tools, metal forming types \\
\hline 470300 & Special dies and tools and machine tool accessories \\
\hline 470401 & Power-driven handtools \\
\hline 470402 & Rolling mill machinery and equipment \\
\hline
\end{tabular}


Table B.2. (contd)

\begin{tabular}{|c|c|}
\hline $\begin{array}{c}\text { Sector } \\
\text { Number }\end{array}$ & 1992 Input-Output Sector Description \\
\hline 470404 & Electric and gas welding and soldering equipment \\
\hline 470405 & Industrial patterns \\
\hline 470500 & Metalworking machinery, n.e.c. \\
\hline \multicolumn{2}{|c|}{48 Special industry machinery and equipment } \\
\hline 480100 & Food products machinery \\
\hline 480200 & Textile machinery \\
\hline 480300 & Woodworking machinery \\
\hline 480400 & Paper industries machinery \\
\hline 480500 & Printing trades machinery and equipment \\
\hline 480600 & Special industry machinery, n.e.c. \\
\hline \multicolumn{2}{|c|}{49 General industrial machinery and equipment } \\
\hline 490100 & Pumps and compressors \\
\hline 490200 & Ball and roller bearings \\
\hline 490300 & Blowers and fans \\
\hline 490500 & Mechanical power transmission equipment \\
\hline 490600 & Industrial process furnaces and ovens \\
\hline 490700 & General industrial machinery and equipment, n.e.c. \\
\hline 490800 & Packaging machinery \\
\hline \multicolumn{2}{|c|}{50 Miscellaneous machinery, except electrical } \\
\hline 500100 & Carburetors, pistons, rings, and valves \\
\hline 500200 & Fluid power equipment \\
\hline 500300 & Scales and balances, except laboratory \\
\hline 500400 & Industrial and commercial machinery and equipment, n.e.c. \\
\hline \multicolumn{2}{|c|}{51 Computer and office equipment } \\
\hline 510102 & Calculating and accounting machines \\
\hline 510103 & Electronic computers \\
\hline 510104 & Computer peripheral equipment \\
\hline 510400 & Office machines, n.e.c. \\
\hline \multicolumn{2}{|c|}{52 Service industry machinery } \\
\hline 520100 & Automatic vending machines \\
\hline 520200 & Commercial laundry equipment \\
\hline 520300 & Refrigeration and heating equipment \\
\hline 520400 & Measuring and dispensing pumps \\
\hline 520500 & Service industry machinery, n.e.c. \\
\hline
\end{tabular}


Table B.2. (contd)

\begin{tabular}{|c|c|}
\hline $\begin{array}{c}\text { Sector } \\
\text { Number }\end{array}$ & 1992 Input-Output Sector Description \\
\hline \multicolumn{2}{|c|}{53 Electrical industrial equipment and apparatus } \\
\hline 530200 & Power, distribution, and specialty transformers \\
\hline 530300 & Switchgear and switchboard apparatus \\
\hline 530400 & Motors and generators \\
\hline 530500 & Relays and industrial controls \\
\hline 530700 & Carbon and graphite products \\
\hline 530800 & Electrical industrial apparatus, n.e.c. \\
\hline \multicolumn{2}{|l|}{$\begin{array}{c}54 \\
\text { Household } \\
\text { appliances }\end{array}$} \\
\hline 540100 & Household cooking equipment \\
\hline 540200 & Household refrigerators and freezers \\
\hline 540300 & Household laundry equipment \\
\hline 540400 & Electric housewares and fans \\
\hline 540500 & Household vacuum cleaners \\
\hline 540700 & Household appliances, n.e.c. \\
\hline \multicolumn{2}{|c|}{55 Electric lighting and wiring equipment } \\
\hline 550100 & Electric lamp bulbs and tubes \\
\hline 550200 & Lighting fixtures and equipment \\
\hline 550300 & Wiring devices \\
\hline \multicolumn{2}{|c|}{56 Audio, video, and communication equipment } \\
\hline 560100 & Household audio and video equipment \\
\hline 560200 & Prerecorded records and tapes \\
\hline 560300 & Telephone and telegraph apparatus \\
\hline 560500 & Communication equipment \\
\hline \multicolumn{2}{|c|}{57 Electronic components and accessories } \\
\hline 570100 & Electron tubes \\
\hline 570200 & Semiconductors and related devices \\
\hline 570300 & Other electronic components \\
\hline \multicolumn{2}{|c|}{58 Miscellaneous electrical machinery and supplies } \\
\hline 580100 & Storage batteries \\
\hline 580200 & Primary batteries, dry and wet \\
\hline 580400 & Electrical equipment for internal combustion engines \\
\hline 580600 & Magnetic and optical recording media \\
\hline 580700 & Electrical machinery, equipment, and supplies, n.e.c. \\
\hline
\end{tabular}

B. 16 
Table B.2. (contd)

\begin{tabular}{|c|c|}
\hline $\begin{array}{c}\text { Sector } \\
\text { Number }\end{array}$ & 1992 Input-Output Sector Description \\
\hline \multicolumn{2}{|c|}{ 59A Motor vehicles (passenger cars and trucks) } \\
\hline 590301 & Motor vehicles and passenger car bodies \\
\hline \multicolumn{2}{|c|}{ 59B Truck and bus bodies, trailers, and motor vehicles parts } \\
\hline 590100 & Truck and bus bodies \\
\hline 590200 & Truck trailers \\
\hline 590302 & Motor vehicle parts and accessories \\
\hline \multicolumn{2}{|c|}{60 Aircraft and parts } \\
\hline 600100 & Aircraft \\
\hline 600200 & Aircraft and missile engines and engine parts \\
\hline 600400 & Aircraft and missile equipment, n.e.c. \\
\hline \multicolumn{2}{|c|}{61 Other transportation equipment } \\
\hline 610100 & Ship building and repairing \\
\hline 610200 & Boat building and repairing \\
\hline 610300 & Railroad equipment \\
\hline 610500 & Motorcycles, bicycles, and parts \\
\hline 610601 & Travel trailers and campers \\
\hline 610603 & Motor homes \\
\hline 610700 & Transportation equipment, n.e.c. \\
\hline \multicolumn{2}{|c|}{62 Scientific and controlling instruments } \\
\hline 620101 & Search and navigation equipment \\
\hline 620102 & Laboratory apparatus and furniture \\
\hline 620200 & Mechanical measuring devices \\
\hline 620300 & Environmental controls \\
\hline 620400 & Surgical and medical instruments and apparatus \\
\hline 620500 & Surgical appliances and supplies \\
\hline 620600 & Dental equipment and supplies \\
\hline 620700 & Watches, clocks, watchcases, and parts \\
\hline 620800 & X-ray apparatus and tubes \\
\hline 620900 & Electromedical and electrotherapeutic apparatus \\
\hline 621000 & Laboratory and optical instruments \\
\hline 621100 & Instruments to measure electricity \\
\hline \multicolumn{2}{|c|}{63 Ophthalmic and photographic equipment } \\
\hline 630200 & Ophthalmic goods \\
\hline 630300 & Photographic equipment and supplies \\
\hline
\end{tabular}


Table B.2. (contd)

\begin{tabular}{|c|c|}
\hline $\begin{array}{c}\text { Sector } \\
\text { Number }\end{array}$ & 1992 Input-Output Sector Description \\
\hline \multicolumn{2}{|c|}{64 Miscellaneous manufacturing } \\
\hline 640101 & Jewelry, precious metal \\
\hline 640102 & Jewelers' materials and lapidary work \\
\hline 640104 & Silverware and plated ware \\
\hline 640105 & Costume jewelry \\
\hline 640200 & Musical instruments \\
\hline 640301 & Games, toys, and children's vehicles \\
\hline 640302 & Dolls and stuffed toys \\
\hline 640400 & Sporting and athletic goods, n.e.c. \\
\hline 640501 & Pens, mechanical pencils, and parts \\
\hline 640502 & Lead pencils and art goods \\
\hline 640503 & Marking devices \\
\hline 640504 & Carbon paper and inked ribbons \\
\hline 640700 & Fasteners, buttons, needles, and pins \\
\hline 640800 & Brooms and brushes \\
\hline 640900 & Hard surface floor coverings, n.e.c. \\
\hline 641000 & Burial caskets \\
\hline 641100 & Signs and advertising specialties \\
\hline 641200 & Manufacturing industries, n.e.c. \\
\hline \multicolumn{2}{|c|}{ 65A Railroads and related services; passenger ground transport } \\
\hline 650100 & Railroads and related services \\
\hline 650200 & Local and suburban transit and interurban highway passenger transportation \\
\hline \multicolumn{2}{|c|}{ 65B Motor freight transportation and warehousing } \\
\hline 650301 & Trucking and courier services, except air \\
\hline 650302 & Warehousing and storage \\
\hline \multicolumn{2}{|c|}{ 65C Water transportation } \\
\hline 650400 & Water transportation \\
\hline \multicolumn{2}{|c|}{ 65D Air transportation } \\
\hline 650500 & Air transportation \\
\hline \multicolumn{2}{|c|}{ 65E Pipelines, freight forwarders, and related services } \\
\hline 650600 & Pipelines, except natural gas \\
\hline 650701 & Freight forwarders and other transportation services \\
\hline 650702 & Arrangement of passenger transportation \\
\hline
\end{tabular}


Table B.2. (contd)

\begin{tabular}{|c|c|}
\hline $\begin{array}{c}\text { Sector } \\
\text { Number }\end{array}$ & 1992 Input-Output Sector Description \\
\hline \multicolumn{2}{|c|}{66 Communications, except radio and TV } \\
\hline 660100 & Telephone, telegraph communications, and communications services, n.e.c \\
\hline 660200 & Cable and other pay television services. \\
\hline \multicolumn{2}{|c|}{67 Radio and TV broadcasting } \\
\hline 670000 & Radio and TV broadcasting \\
\hline \multicolumn{2}{|c|}{ 68A Electric services (utilities) } \\
\hline 680100 & Electric services (utilities) \\
\hline \multicolumn{2}{|c|}{ 68B Gas production and distribution (utilities) } \\
\hline 680201 & Natural gas transportation \\
\hline 680202 & Natural gas distribution \\
\hline \multicolumn{2}{|c|}{ 68C Water and sanitary services } \\
\hline 680301 & Water supply and sewerage systems \\
\hline 680302 & Sanitary services, steam supply, and irrigation systems \\
\hline \multicolumn{2}{|c|}{ 69A Wholesale trade } \\
\hline 690100 & Wholesale trade \\
\hline \multicolumn{2}{|c|}{ 69B Retail trade } \\
\hline 690200 & Retail trade, except eating and drinking \\
\hline \multicolumn{2}{|c|}{ 70A Finance } \\
\hline 700100 & Banking \\
\hline 700200 & Credit agencies other than banks \\
\hline 700300 & Security and commodity brokers \\
\hline \multicolumn{2}{|c|}{ 70B Insurance } \\
\hline 700400 & Insurance carriers \\
\hline 700500 & Insurance agents, brokers, and services \\
\hline \multicolumn{2}{|c|}{ 71A Owner-occupied dwellings } \\
\hline 710100 & Owner-occupied dwellings \\
\hline \multicolumn{2}{|c|}{ 71B Real estate and royalties } \\
\hline 710201 & Real estate agents, managers, operators, and lessors \\
\hline 710202 & Royalties \\
\hline \multicolumn{2}{|c|}{ 72A Hotels and lodging places } \\
\hline 720101 & Hotels \\
\hline 720102 & Other lodging places \\
\hline
\end{tabular}


Table B.2. (contd)

\begin{tabular}{|c|c|}
\hline $\begin{array}{c}\text { Sector } \\
\text { Number }\end{array}$ & 1992 Input-Output Sector Description \\
\hline \multicolumn{2}{|c|}{ 72B Personal and repair services (except auto) } \\
\hline 720201 & Laundry, cleaning, garment services, and shoe repair \\
\hline 720202 & Funeral service and crematories \\
\hline 720203 & Portrait photographic studios, and other miscellaneous personal services \\
\hline 720204 & Electrical repair shops \\
\hline 720205 & Watch, clock, jewelry, and furniture repair \\
\hline 720300 & Beauty and barber shops \\
\hline \multicolumn{2}{|c|}{ 73A Computer and data processing services } \\
\hline 730104 & Computer and data processing services \\
\hline \multicolumn{2}{|c|}{ 73B Legal, engineering, accounting, and related services } \\
\hline 730301 & Legal services \\
\hline 730302 & Engineering, architectural, and surveying services \\
\hline 730303 & Accounting, auditing and bookkeeping, and miscellaneous services, n.e.c. \\
\hline \multicolumn{2}{|c|}{ 73C Other business and professional services, except medical } \\
\hline 730101 & Miscellaneous repair shops \\
\hline 730102 & Services to dwellings and other buildings \\
\hline 730103 & Personnel supply services \\
\hline 730106 & Detective and protective services \\
\hline 730107 & Miscellaneous equipment rental and leasing \\
\hline 730108 & Photofinishing labs and commercial photography \\
\hline 730109 & Other business services \\
\hline 730111 & Management and public relations services \\
\hline 730112 & Research, development, and testing services, except noncommercial \\
\hline \multicolumn{2}{|c|}{ 73D Advertising } \\
\hline 730200 & Advertising \\
\hline \multicolumn{2}{|c|}{74 Eating and drinking places } \\
\hline 740000 & Eating and drinking places \\
\hline \multicolumn{2}{|c|}{75 Automotive repair and services } \\
\hline 750001 & Automotive rental and leasing, without drivers \\
\hline 750002 & Automotive repair shops and services \\
\hline 750003 & Automobile parking and car washes \\
\hline
\end{tabular}


Table B.2. (contd)

\begin{tabular}{|c|c|}
\hline $\begin{array}{c}\text { Sector } \\
\text { Number }\end{array}$ & 1992 Input-Output Sector Description \\
\hline \multicolumn{2}{|c|}{76 Amusements } \\
\hline 760101 & Motion picture services and theaters \\
\hline 760102 & Video tape rental \\
\hline 760201 & Theatrical producers (except motion picture), bands, orchestras and entertainers \\
\hline 760202 & Bowling centers \\
\hline 760203 & Professional sports clubs and promoters \\
\hline 760204 & Racing, including track operation \\
\hline 760205 & Physical fitness facilities and membership sports and recreation clubs \\
\hline 760206 & Other amusement and recreation services \\
\hline \multicolumn{2}{|c|}{ 77A Health services } \\
\hline 770100 & Doctors and dentists \\
\hline 770200 & Hospitals \\
\hline 770301 & Nursing and personal care facilities \\
\hline 770303 & Other medical and health services \\
\hline 770304 & Veterinary services \\
\hline 770305 & Other medical and health services \\
\hline \multicolumn{2}{|c|}{ 77B Educational and social sve, and membership organizations } \\
\hline 770401 & Elementary and secondary schools \\
\hline 770402 & Colleges, universities, and professional schools \\
\hline 770403 & Private libraries, vocational schools, and educational services, n.e.c. \\
\hline 770501 & Business associations and professional membership organizations \\
\hline 770502 & Labor organizations, civic, social, and fraternal associations \\
\hline 770503 & Religious organizations \\
\hline 770504 & Other membership organizations \\
\hline 770600 & Job training and related services \\
\hline 770700 & Child day care services \\
\hline 770800 & Residential care \\
\hline 770900 & Social services, n.e.c. \\
\hline \multicolumn{2}{|c|}{78 Federal Government enterprises } \\
\hline 780100 & U.S. Postal Service \\
\hline 780200 & Federal electric utilities \\
\hline 780500 & Other Federal Government enterprises \\
\hline
\end{tabular}


Table B.2. (contd)

\begin{tabular}{|c|c|}
\hline $\begin{array}{c}\text { Sector } \\
\text { Number }\end{array}$ & 1992 Input-Output Sector Description \\
\hline \multicolumn{2}{|c|}{79 State and local government enterprises } \\
\hline 790100 & State and local government passenger transit \\
\hline 790200 & State and local government electric utilities \\
\hline 790300 & Other State and local government enterprises \\
\hline \multicolumn{2}{|c|}{80 Noncomparable imports } \\
\hline 800000 & Noncomparable imports \\
\hline \multicolumn{2}{|c|}{81 Scrap, used and secondhand goods } \\
\hline 810001 & Scrap \\
\hline 810002 & Used and secondhand goods \\
\hline \multicolumn{2}{|c|}{82 General government industry } \\
\hline 820000 & General government industry \\
\hline \multicolumn{2}{|c|}{83 Rest of the world adjustment to final uses } \\
\hline 830001 & Rest of the world adjustment to final uses \\
\hline \multicolumn{2}{|c|}{84 Household industry } \\
\hline 840000 & Household industry \\
\hline \multicolumn{2}{|c|}{85 Inventory valuation adjustment } \\
\hline 850000 & Inventory valuation adjustment \\
\hline \multicolumn{2}{|c|}{88 Compensation of employees } \\
\hline 880000 & Compensation of employees \\
\hline \multicolumn{2}{|c|}{89 Indirect business tax and nontax liability } \\
\hline 890000 & Indirect business tax and nontax liability \\
\hline \multicolumn{2}{|c|}{90 Other value added } \\
\hline 900000 & Other value added \\
\hline \multicolumn{2}{|c|}{91 Personal consumption expenditures } \\
\hline 910000 & Personal consumption expenditures \\
\hline \multicolumn{2}{|c|}{92 Gross private fixed investment } \\
\hline 920000 & Gross private fixed investment \\
\hline \multicolumn{2}{|c|}{93 Change in business inventories } \\
\hline 930000 & Change in business inventories \\
\hline \multicolumn{2}{|c|}{94 Exports of goods and services } \\
\hline 940000 & Exports of goods and services \\
\hline \multicolumn{2}{|c|}{95 Imports of goods and services } \\
\hline 950000 & Imports of goods and services investment \\
\hline
\end{tabular}


Table B.2. (contd)

\begin{tabular}{|c|c|}
\hline \multicolumn{2}{|c|}{ 96C Federal Government consumption expend: National defense } \\
\hline $9600 \mathrm{C} 0$ & Federal Government consumption expenditures, national defense, \\
\hline \multicolumn{2}{|c|}{ 96I Federal Government gross investment: National defense } \\
\hline 9600I0 & Federal Government gross investment, national defense, gross \\
\hline \multicolumn{2}{|c|}{ 97C Federal Government consumption expenditures: Nondefense } \\
\hline $9700 \mathrm{C} 0$ & Federal Government consumption expenditures, nondefense, consumption \\
\hline \multicolumn{2}{|c|}{ 97I Federal Government gross investment: Nondefense } \\
\hline 9700I0 & Federal Government gross investment, nondefense expenditures \\
\hline \multicolumn{2}{|c|}{ 98C State and local government consumption expend: Education } \\
\hline $9800 \mathrm{C} 1$ & $\begin{array}{l}\text { State and local government consumption expenditures, elementary and secondary } \\
\text { public school systems, consumption expenditures }\end{array}$ \\
\hline $9800 \mathrm{C} 2$ & $\begin{array}{l}\text { State and local government consumption expenditures, public educational facilities } \\
\text { beyond high school, consumption expenditures }\end{array}$ \\
\hline 9800C3 & $\begin{array}{l}\text { State and local government consumption expenditures, other education and libraries, } \\
\text { consumption expenditures }\end{array}$ \\
\hline \multicolumn{2}{|c|}{ 98I State and local government gross investment: Education } \\
\hline $9800 \mathrm{I} 1$ & $\begin{array}{l}\text { State and local government gross investment, elementary and secondary public school } \\
\text { systems, gross investment }\end{array}$ \\
\hline $9800 \mathrm{I} 2$ & $\begin{array}{l}\text { State and local government gross investment, public educational facilities beyond } \\
\text { high school, gross investment }\end{array}$ \\
\hline 9800I3 & $\begin{array}{l}\text { State and local government gross investment, other education and libraries, gross } \\
\text { investment }\end{array}$ \\
\hline \multicolumn{2}{|c|}{ 99C State and local government consumption expenditures: Other } \\
\hline $9910 \mathrm{C} 1$ & $\begin{array}{l}\text { State and local government consumption expenditures, hospitals and categorical } \\
\text { health programs, consumption expenditures }\end{array}$ \\
\hline $9910 \mathrm{C} 2$ & $\begin{array}{l}\text { State and local government consumption expenditures, public welfare institutions and } \\
\text { activities, consumption expenditures }\end{array}$ \\
\hline 9910C4 & $\begin{array}{l}\text { State and local government consumption expenditures, sanitation, consumption } \\
\text { expenditures }\end{array}$ \\
\hline $9920 \mathrm{I3}$ & $\begin{array}{l}\text { State and local government gross investment, correctional institutions, gross } \\
\text { investment }\end{array}$ \\
\hline 9920C1 & $\begin{array}{l}\text { State and local government consumption expenditures, police, consumption } \\
\text { expenditures }\end{array}$ \\
\hline $9920 \mathrm{C} 2$ & $\begin{array}{l}\text { State and local government consumption expenditures, fire fighting organizations and } \\
\text { auxiliary services, consumption expenditures }\end{array}$ \\
\hline 9920C3 & $\begin{array}{l}\text { State and local government consumption expenditures, correctional institutions, } \\
\text { consumption expenditures }\end{array}$ \\
\hline
\end{tabular}


Table B.2. (contd)

\begin{tabular}{|c|c|}
\hline $\begin{array}{c}\text { Sector } \\
\text { Number }\end{array}$ & 1992 Input-Output Sector Description \\
\hline $9930 \mathrm{C} 1$ & $\begin{array}{l}\text { State and local government consumption expenditures, public highways (non-capital } \\
\text { expenditures of toll roads), consumption expenditures }\end{array}$ \\
\hline 9930C8 & $\begin{array}{l}\text { State and local government consumption expenditures, natural and agricultural } \\
\text { resources and recreation facilities, consumption expenditures }\end{array}$ \\
\hline 9930C9 & $\begin{array}{l}\text { State and local government consumption expenditures, other general government } \\
\text { activities, n.e.c, consumption expenditures }\end{array}$ \\
\hline \multicolumn{2}{|c|}{ 99I State and local government gross investment: Other } \\
\hline $9910 \mathrm{I1}$ & $\begin{array}{l}\text { State and local government gross investment, hospitals and categorical health } \\
\text { programs, gross investment }\end{array}$ \\
\hline $9910 \mathrm{I} 2$ & $\begin{array}{l}\text { State and local government institutions and activities, gross investment, public } \\
\text { welfare investment }\end{array}$ \\
\hline $9910 \mathrm{I3}$ & $\begin{array}{l}\text { State and local government gross investment, public sewerage systems, gross } \\
\text { investment }\end{array}$ \\
\hline $9910 \mathrm{I} 4$ & State and local government gross investment, sanitation, gross investment \\
\hline $9920 \mathrm{I1}$ & State and local government gross investment, police, gross investment \\
\hline $9920 \mathrm{I} 2$ & $\begin{array}{l}\text { State and local government gross investment, fire fighting organizations and auxiliary } \\
\text { services, gross investment }\end{array}$ \\
\hline 9930I1 & State and local government gross investment, public highways, gross investment \\
\hline $9930 \mathrm{I} 2$ & $\begin{array}{l}\text { State and local government gross investment, water sports and airports, gross } \\
\text { investment }\end{array}$ \\
\hline $9930 \mathrm{I3}$ & $\begin{array}{l}\text { State and local government gross investment, government-operated transit systems, } \\
\text { gross investment }\end{array}$ \\
\hline $9930 \mathrm{I} 4$ & $\begin{array}{l}\text { State and local government gross investment, other commerce activities n.e.c., gross } \\
\text { investment }\end{array}$ \\
\hline $9930 I 5$ & $\begin{array}{l}\text { State and local government gross investment, gas and electric utilities, gross } \\
\text { investment }\end{array}$ \\
\hline $9930 \mathrm{I} 6$ & $\begin{array}{l}\text { State and local government gross investment, government-operated water supply } \\
\text { facilities, gross investment }\end{array}$ \\
\hline $9930 \mathrm{I7}$ & $\begin{array}{l}\text { State and local government gross investment, redevelopment projects, gross } \\
\text { investment }\end{array}$ \\
\hline 9930I8 & $\begin{array}{l}\text { State and local government gross investment, natural and agricultural resources and } \\
\text { recreation facilities, gross investment }\end{array}$ \\
\hline 9930I9 & $\begin{array}{l}\text { State and local government gross investment, other general government activities, } \\
\text { n.e.c, gross investment }\end{array}$ \\
\hline
\end{tabular}




\section{Appendix C}

\section{FORTRAN Calculator}

This appendix describes the input file generated by the Visual Basic program IBLD20, three FORTRAN routines used to do the calculations, and the output file that returns the calculations to IBLD20.

\section{C.1 The Input File}

The FORTRAN calculator is designed to process a data stream generated by the program ImBuild 2.0. Such a file, labeled "qminput.txt," is shown below in the box.

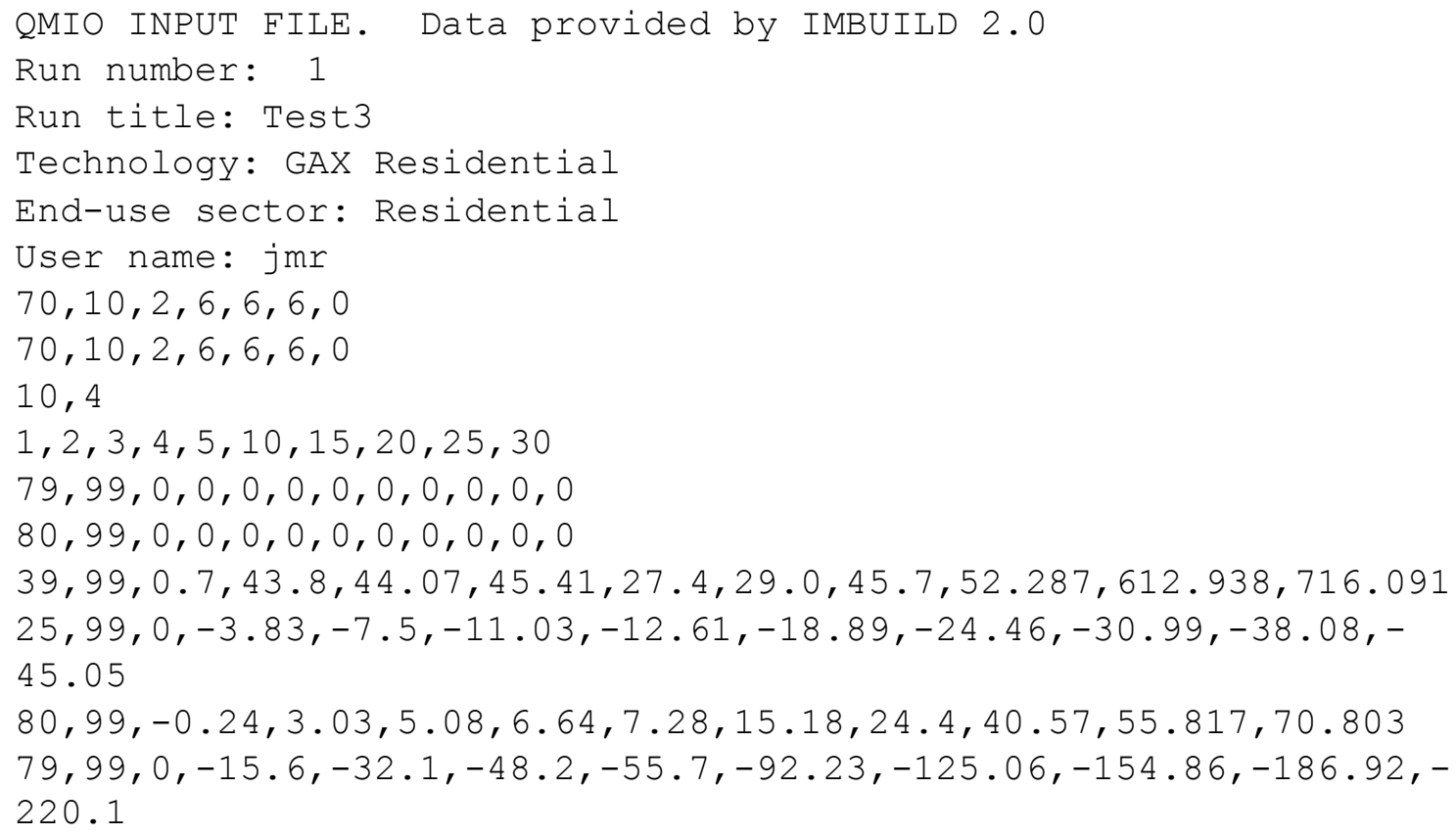

The file contains six lines of text ending with the user name. The text is followed by two sets of seven weights (the two lines beginning with 70,10 , etc.), a line that tells the calculator how many years of data are included (10) and the number of changes to read (4), and the year numbers $(1,2$, etc.). These year numbers are added to 2000 so the results are reported as 2001, 2002, etc. Following the year numbers, there are two lines that report the capacity adjustments as a result of energy savings, one for electricity (79) and one for gas utilities (80). In this case, there are no changes to capacity, so all ten of the numbers are zero. Following these capacity changes are four sets of changes to the data, one for each of the sectors 39, 25, 80, and 79. Cross referencing these sectors (see Appendix A) reveals that the changes are 
for heating equipment (39), petroleum products, gas, and electricity sectors. For a gas heat pump, the equipment purchases and incremental gas use are positive, while this equipment saves on electricity and heating oil.

The second index number, 99, indicates that these changes are to be made to the final demand vector. If commercial equipment was considered rather than residential equipment, there would be changes to other industry sectors which would be represented by the second index number and would be one of the 98 industries identified in Appendix B.

\section{C.2 The FORTRAN Programs}

There is a FORTRAN main program, IBLDCALC, which calls two FORTRAN subroutines, QM3 and DEMAND. The main program reads in the data file described above and transfers the data to the calculating subroutine QM3, which returns the results to the main program and writes the data file that is then read by the VB program. The subroutine QM3 first reads the core data from a binary file that holds the 1992 Benchmark I-O data, then calculates the base period employment, earnings, and output. It then loops through each of the years to be processed, changing the Use matrix data or the final demand data, then recalculating the employment, earnings and output. When all years are processed, the routine transfers the results back to the main program. In the course of this processing, QM3 calls the DEMAND subroutine to make adjustments to final demands and assure that the final demand vector is appropriately rescaled. In addition, there are five other routines that multiply, add, and invert matrices, which are briefly described but not shown here.

\section{C.2.1 The Main Program, IBLDCALC}

The main program, IBLDCALC, is shown in the text boxes on the next two pages. While comments in the code explain most of the operations, this explanation will be cued to the input file, shown above. After a number of parameter and variable definitions, the program opens two files, the input file above, and the file to which the results will be printed, QM-CHG.DAT. The program then skips over the six lines of text that are not used by the calculator. The next read statements put the first set of seven weights into the variable iwgt, and the second set of weights into the variable jwgt. Since these are read in as integer percentages, they are converted to floating point decimal numbers in the loop that begins, DO 14. The next two read statements assign the number of years processed to JYR and the number of changes to be made to $\mathrm{N}$.

The continuation text box begins with reading the capacity changes into the variable $y$ and all the I-O changes into X. Two other variables, inx and indx, hold the set of industry or final demand indexes.

At this point the program has input the data stream and turns over processing to QM3. When the results are returned from QM3, they are contained in six variables: SUMJ, SUMH, and SUMQ contain the base period jobs, earnings and total output. The vectors SJ, SH, and SQ contain the calculated model results, one for each year, of which there are JYR $(=10)$ years. The program next prints the base period values to the output file, then calculates and prints out the difference between subsequent year calculated values and the base period values to this same file. 
The program is then completed, so control is transferred back to the VB program.

\section{C.2.2. The Calculator - QM32}

The lengthy text box on pages C.6 through C.8 is a listing of the calculation routine, QM3. The first set of comments explains how the naming convention changes from the main program within this routine. Parameters and variables are than defined and the binary file that contains the 1992 Benchmark I-O data is opened. The variables read from this file are $\mathrm{D}$, the market share matrix (derived from the make matrix), U, the use matrix, Q, the vector of industry outputs, DF, the final demand matrix, and EI, the matrix of employment and earnings intensity by industry. The dimensionality of each of these variables can be determined from the variable definitions at the beginning of the program.

Once the I-O data is returned, the data are used to construct the base period employment, earnings and output. Base period results are constructed by multiplying industry output, the first column of Q, by two sets of industry intensities. These intensities are found in the variable EI, with the first column job intensities and the second earnings intensities. Multiplying each industry's output by these intensities yields jobs and earning, which are cumulated over all industries. Total output is also cumulated and returned in the scalar variables SUJ, SUE, and SUQ, as indicated in the comments on page C.6 in the comments after statement numbered 63. The last set of statements on this page first zero out the set of variables used to differentiate between changes to capital purchases, changes to fuel use and changes in water use. Then, beginning on page C.7, vectors are defined that allow the program to identify which changes fall into each of these categories. These are the vectors, FL, KL, and WL, consisting of zeros and ones, where the units identify the change as falling into the specific categories, with $\mathrm{F}, \mathrm{K}$, and $\mathrm{W}$ referencing fuel, capital and water respectively.

After these assignments, QM3 begins processing each year's data. The processing of each year begins by rewinding and re-reading the binary file that contains the I-O data, to assure that any changes will be made to the original data, since the changes to this data will be different for each year. Then after zeroing out two variables to hold the sum of final demand and the sum of changes to value added, identified by fuel type, the total to capacity adjustment is calculated for this year. That is stored in the variable ADJK. Then the changes to final demand and the use matrix are made, identifying the capital, fuel, and water final demand changes separately. The value-added changes to the use matrix are made to each of the appropriate columns, then cumulated by fuel. While specific industries have their use of the fuels adjusted within the use matrix, the impact on the fuel supplying industry is applied to the final demand vector.

Once these changes are made and results for this year have been zeroed out, I-O data are processed to create a total requirements matrix. This is done by creating a matrix, $\mathrm{B}$, which is derived from the use matrix by dividing each element in the columns by that industry's output. This loop is also used to create the identity matrix ai. Then B is premultiplied by $\mathrm{D}$, the market share matrix - this is derived from the make matrix. This matrix multiplication relies on a call to a matrix multiply subroutine, MMULT, which multiplies a ( $\mathrm{kx} \mathrm{n})$ matrix by a second $(\mathrm{n} \times \mathrm{m})$ matrix and returns a $(\mathrm{k} \times \mathrm{m})$ matrix. A similar routine, MMULT1, multiplies a ( $\mathrm{kx} \mathrm{n})$ matrix by an ( $\mathrm{n} \times 1)$ vector to create a $(\mathrm{k} \times 1)$ vector. This $\mathrm{B} * \mathrm{D}$ matrix (called " $\mathrm{a}$ " in the program) is then subtracted from the identity matrix, ai, using the subroutine MADD 
(which adds or subtracts, depending on the value of $\mathrm{j},-1$ in this case for subtraction). The result, which replaces the Use matrix, is then inverted using two subroutine from Numerical Recipes ${ }^{(a)}$. The resulting inverse (replacing ai) then is premultiplied by the market share matrix to yield the total requirements matrix, labeled $t$. At this point, we are ready to create the final demand vector, so a call is made to the subroutine DEMAND. This returns the final demand vector $\mathrm{x}$, which is then premultiplied by the total requirements matrix, $t$, to yield the output vector, $y$. Output then is multiplied by each column of the intensity matrix to yield this year's jobs, and earnings. This period's output is then just the sum of all of the industry outputs. When each of the JYRs of data have been processed, the big loop is complete and the results are returned to the main program.

(a) Press, William H., et al. 1986. Numerical Recipes: The Art of Scientific Computing. New York: Cambridge University Press. For matrix inversion, see p. 38. 


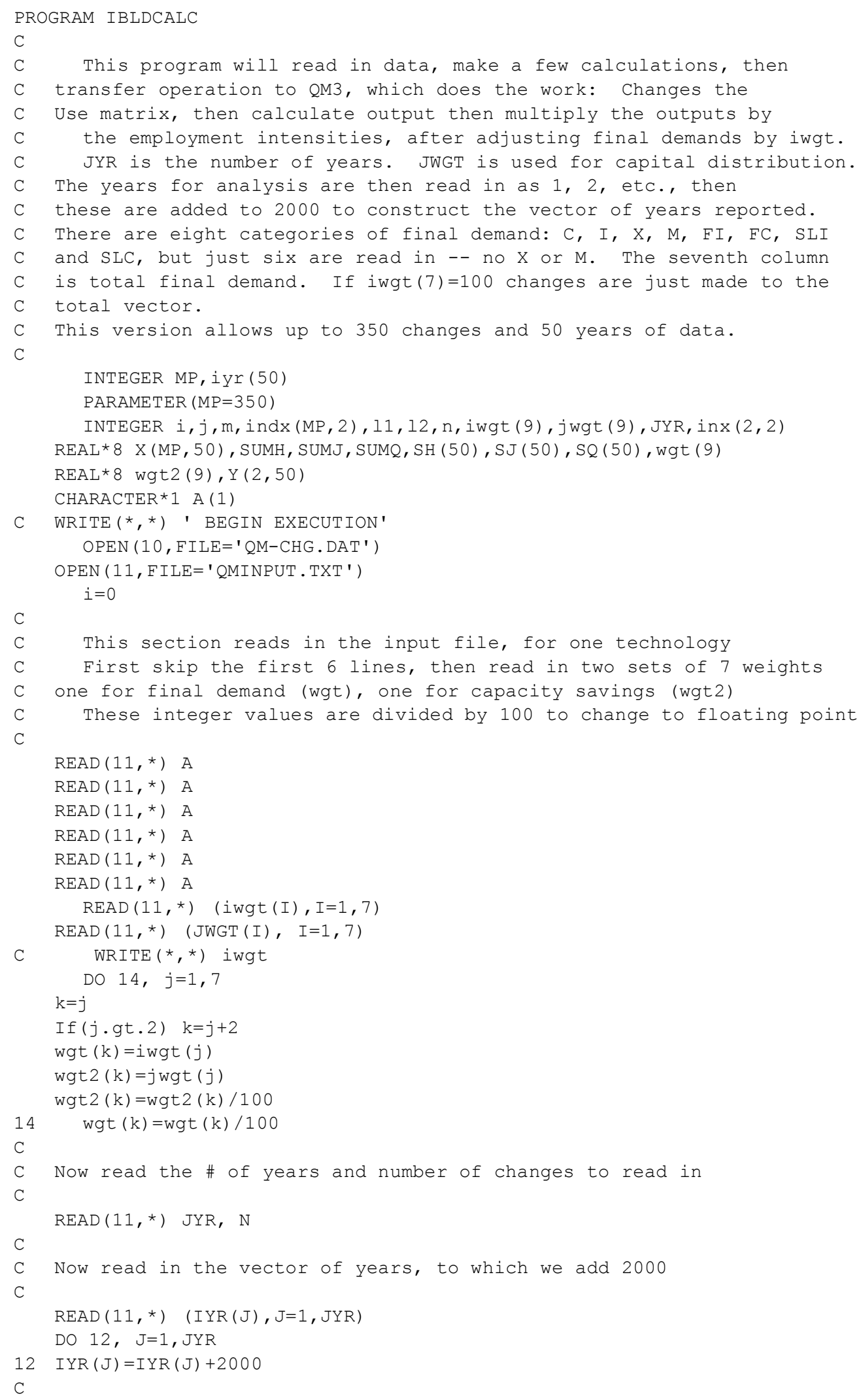




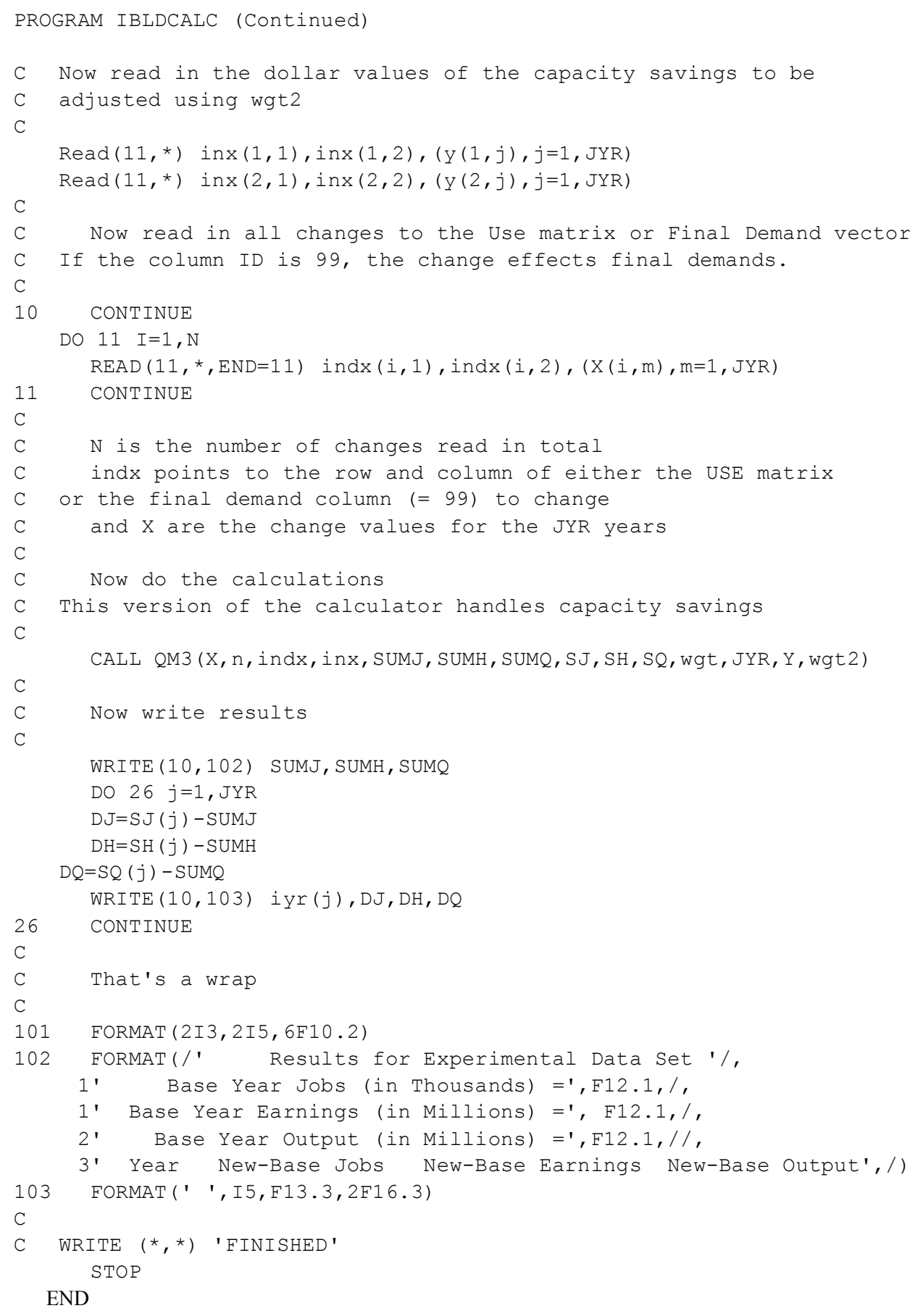




\section{C.2.3 Changing Final Demands -- DEMAND}

The call to this transfers the changes to final demand read in by the main program, contained in the vectors $\mathrm{CV}, \mathrm{CF}, \mathrm{CK}$, and $\mathrm{CW}$, and the array of final demands, $\mathrm{DF}$, read in from the binary file. In addition, the weights to distribute the financing charges and the weights to allocate the capacity changes are transferred in the wgt and WGT2, along with the value of the capacity changes, contained in ADJK. Finally, all the value-added variables, a total and a variable for each of the fuel changes, are transferred. The first set of statements below the initial comments zero out cumulators, aggregate the finance and capacity weights, and sum each of the components of final demand. The ninth column in this array is the total final demand vector, with the other columns corresponding to consumption, investment, exports, imports, Federal government investment and consumption and state and local investment and consumption. The next block of calculations zero out the vector of final demands to be returned and cumulates the changes to final demand partitioning these changes into capital purchases, which affect investment, and fuel and water purchases, which affect consumption.

The next block of code treats the case where final demand is treated as an aggregate rather than being concerned about the financing being distributed across components of final demand. This case first checks to see if the final weight associated with financing is one. If not, the routine branches to statement 15 near the end of the page and continues on the next page. Otherwise, the changes to final demand are combined with the total final demand vector. Recall that in the case of investment purchases, these will be positive, while energy savings will be negative. All final demand savings to consumption are renormalized back to the original consumption total while the investments are financed according to the total finance weight, sw. Then if there are capacity adjustments to be made, these are subtracted from the "Other Investment" activity that is in row six of the final demand vector. The two scalars created to make these adjustments are used to expand (or contract) the vector of final demand so it is scaled appropriately. 


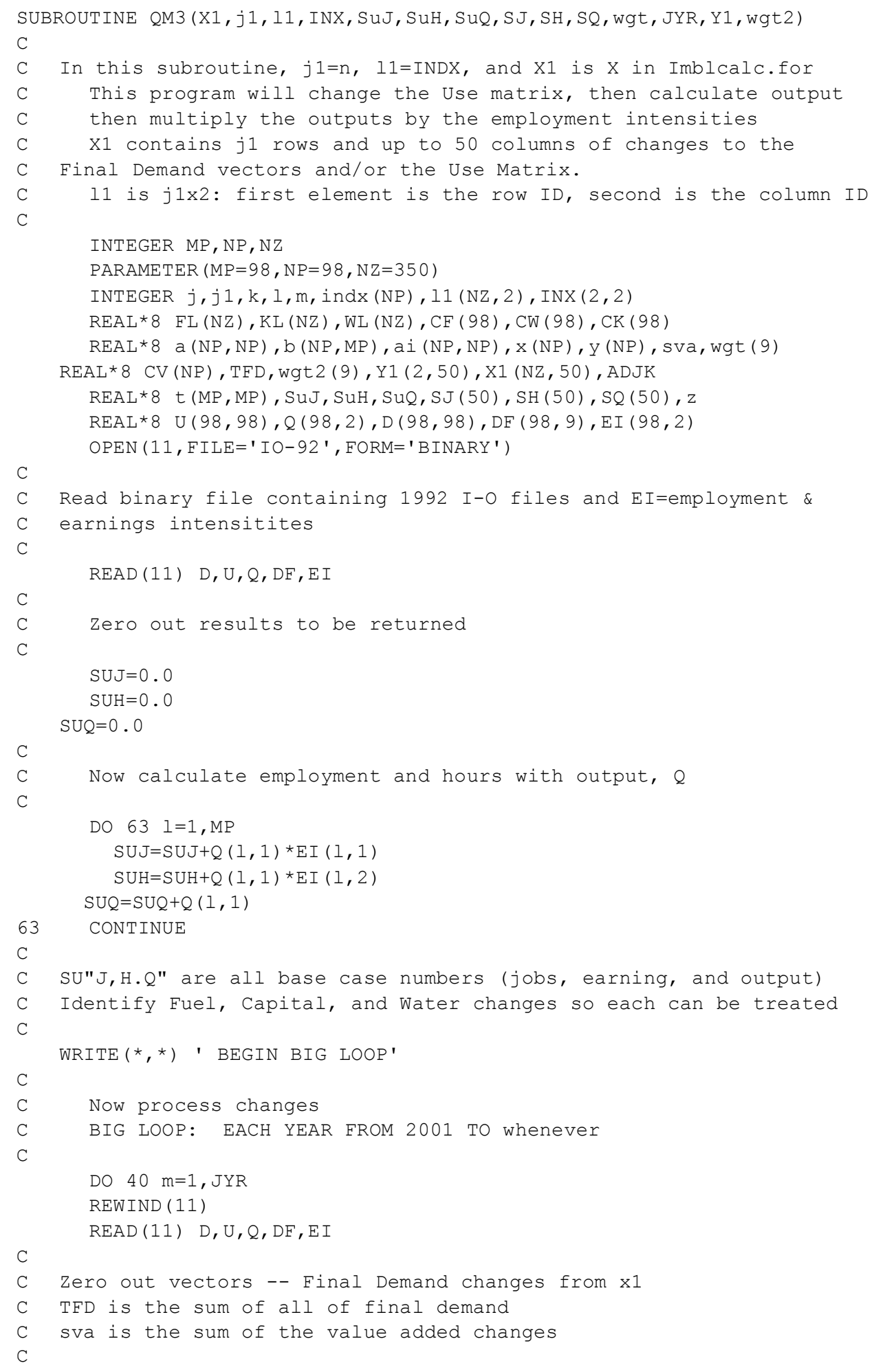




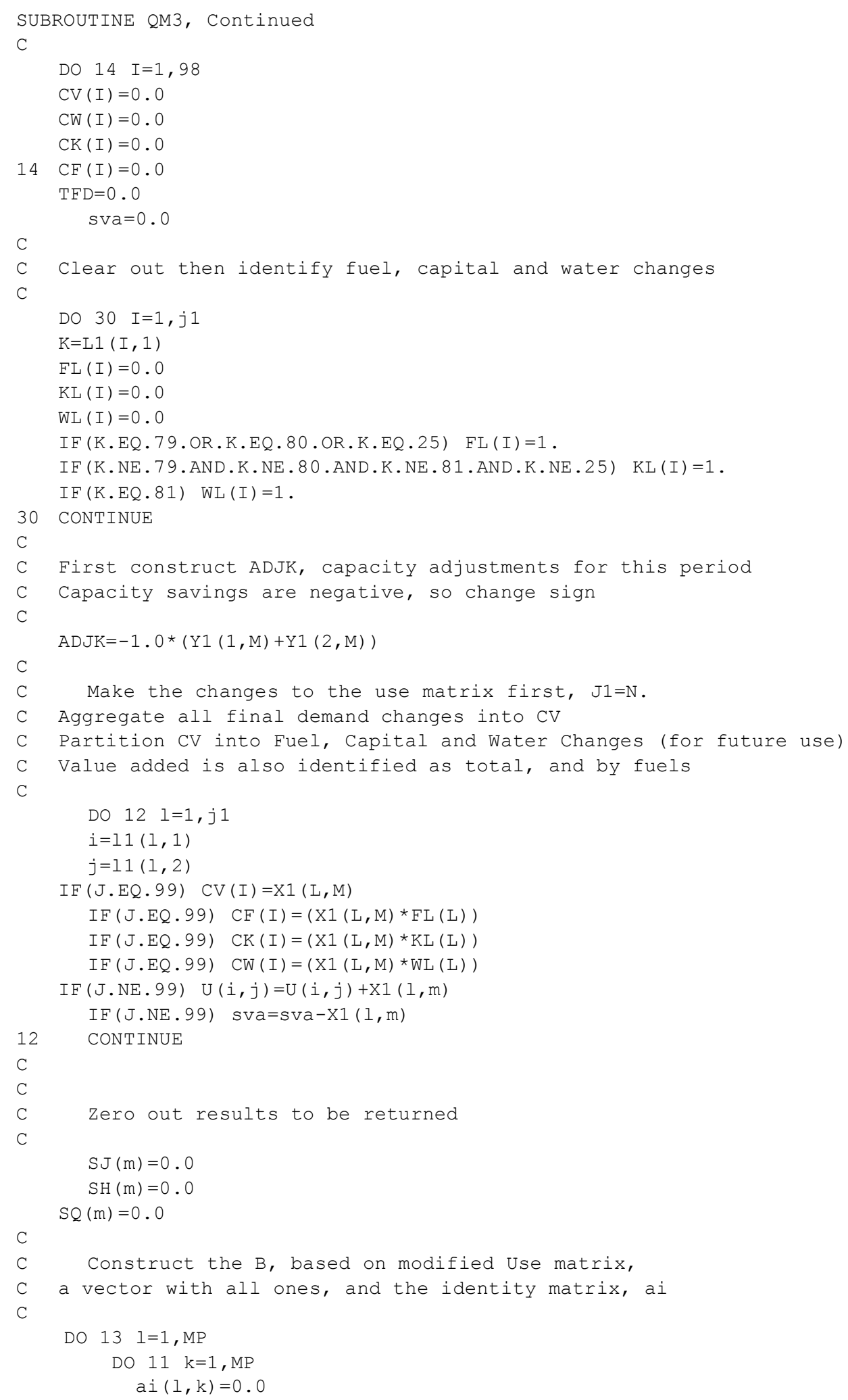




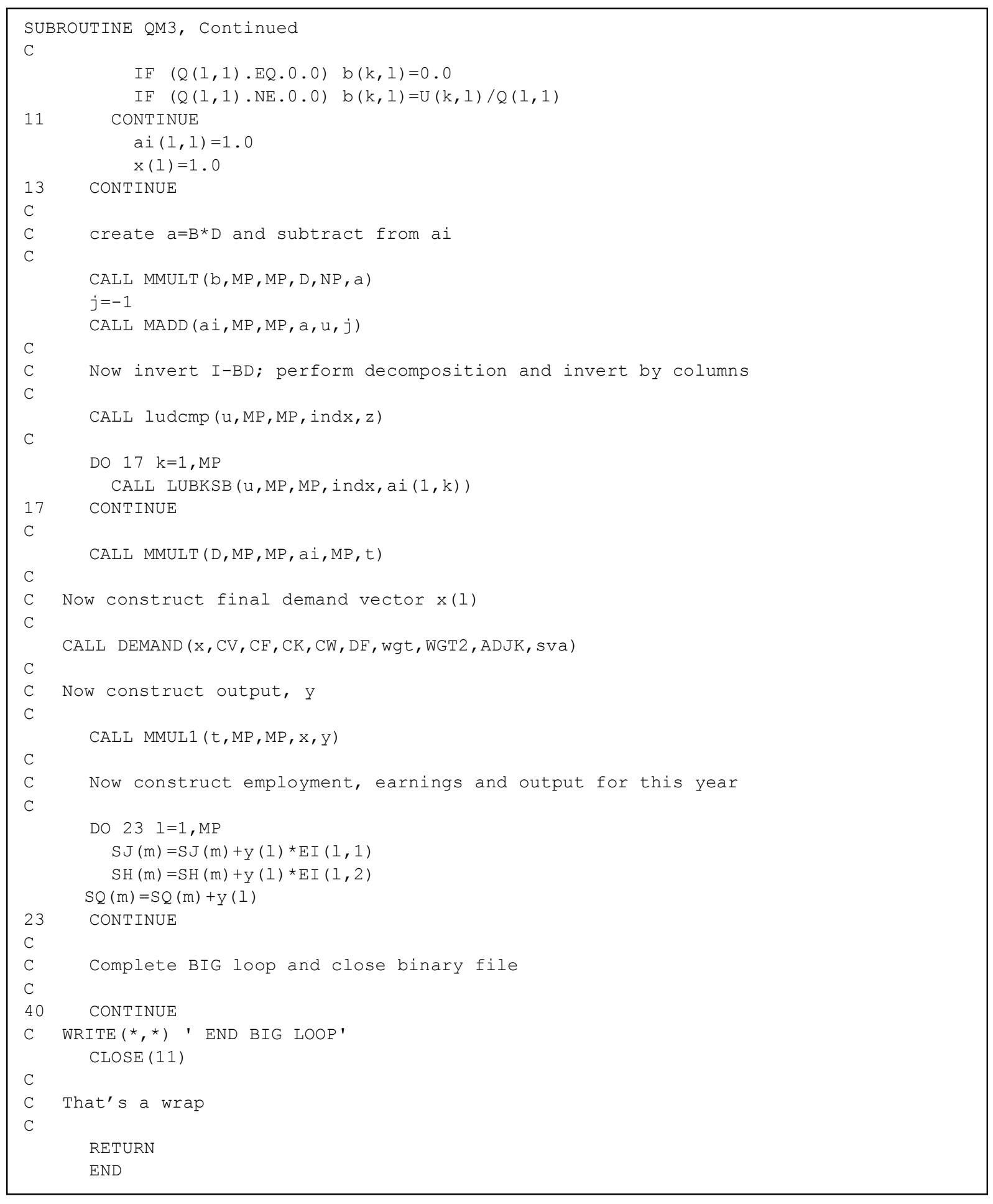


These capacity adjustments might not be fully added back in, depending on sum of the capacity weights. This scalar adjusts the vector of final demand that will be returned and the program branches to the concluding section that makes adjustments to this vector of final demand to correct for value added changes. These changes will be considered after we handle the case where final demand is not handled as a single vector, which begins on page C.10.

In the event that weights are specified, financing of capital expenditures (i.e., the source of these funds) is to be extracted from other final demand sectors according to those weights. Similarly, if weights are defined for capacity savings, these must be redistributed (i.e., returned) to the categories of final demand specified by the weights. Either of these reallocations will alter the distributions of the separate categories of final demand which will, in turn, affect the aggregated final demand vector slightly differently than if the total vector was adjusted. Recall that all fuel savings to consumption are redistributed back to consumptions. These adjustments begin with the creation of a new variable, Y, which is structured like the eight columns of final demand.

The first step is to "add" (usually subtract, since these costs are saved) the fuel and water expenditure changes to consumption expenditures and the capital expenditures to the investment column. Then these expenditures are added to each of the columns of final demand. First we adjust consumption to reflect that savings are reallocated. Then a vector of adjustment scalars is constructed that allocates the cost of the equipment among the components of final demand, according to the weights. Then each component of final demand is scaled to adjust for the changes made to investment and new totals (sy1) are calculated.

The next step adjusts for capacity changes. Capacity savings reduce "other" (heavy industrial) construction, which is row six of the investment vector. The sum of this vector is also adjusted and these savings are reallocated to other sectors according to the vector wgt2. This reallocation requires the calculation of another set of adjustment multipliers, which are used to scale each of the final demand vectors again. After these two adjustments have been made, the eight columns of final demand are added to construct the total final demand vector, $\mathrm{x}$, and cumulate the sum in the scalar SCV. The remaining task is the adjustment for changes in value-added if changes were made to the use matrix. (The continuation statement 45 shows the entry point from the section where final demand is treated as a single vector; recall that the same variable, SCV, was used to sum total final demand.) A scaling multiplier, $\mathrm{z} 1$, is constructed by adding the sum of value added, SVA, to SCV, then dividing by SCV. Z1 is then used to multiply each element of the final demand vector $\mathrm{x}$, which is then returned to QM3. 


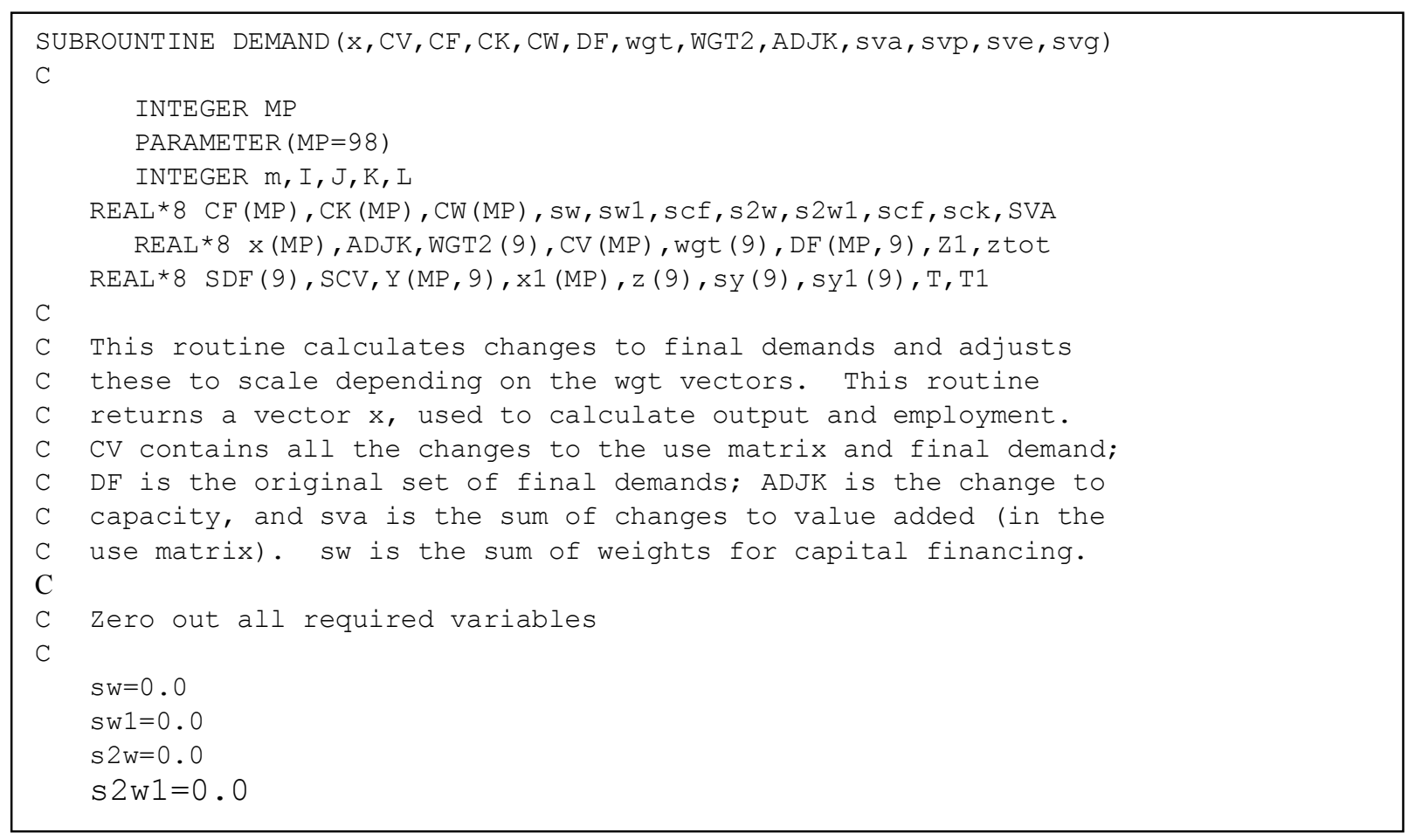

\section{12}




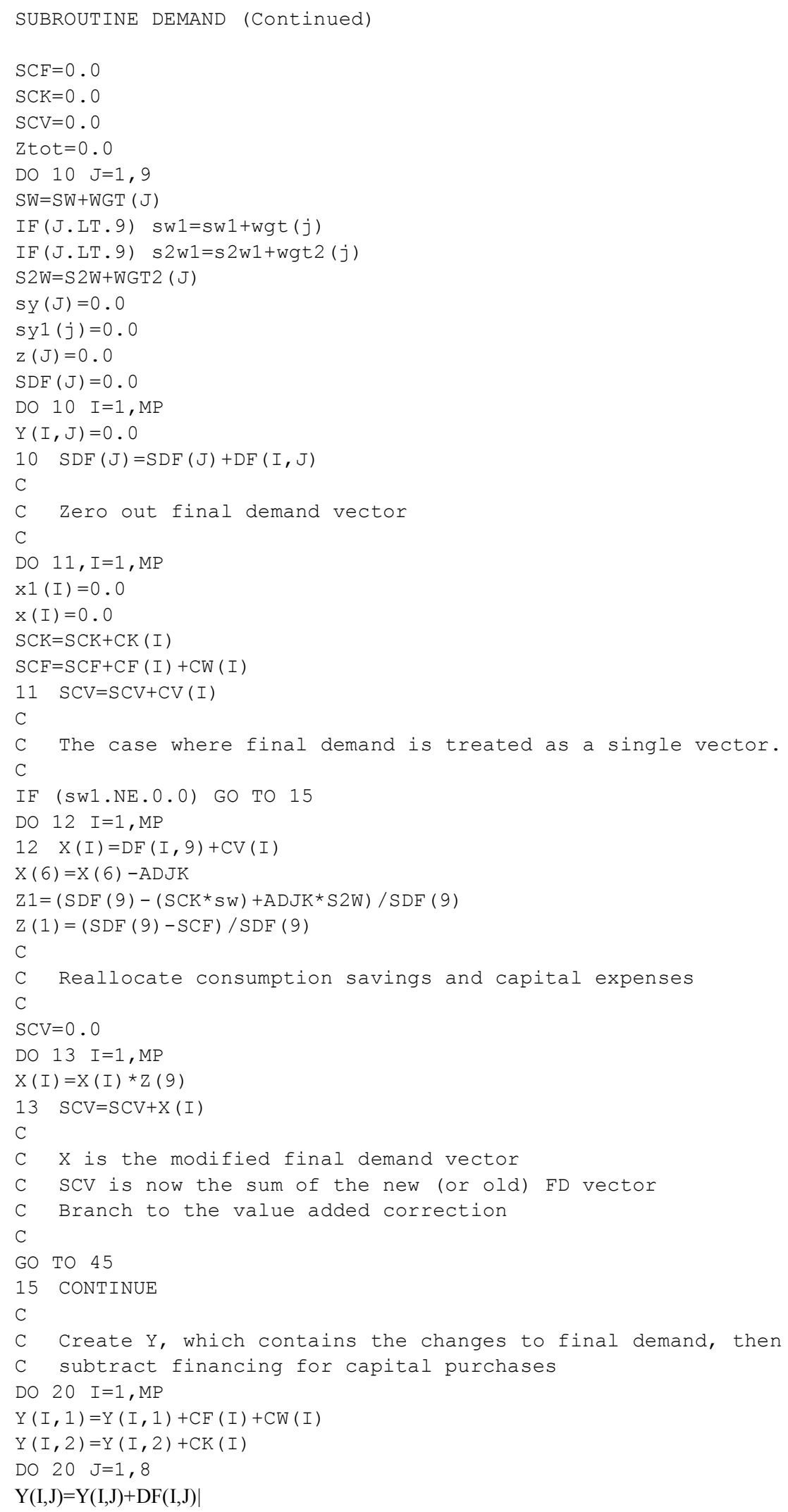

C. 13 


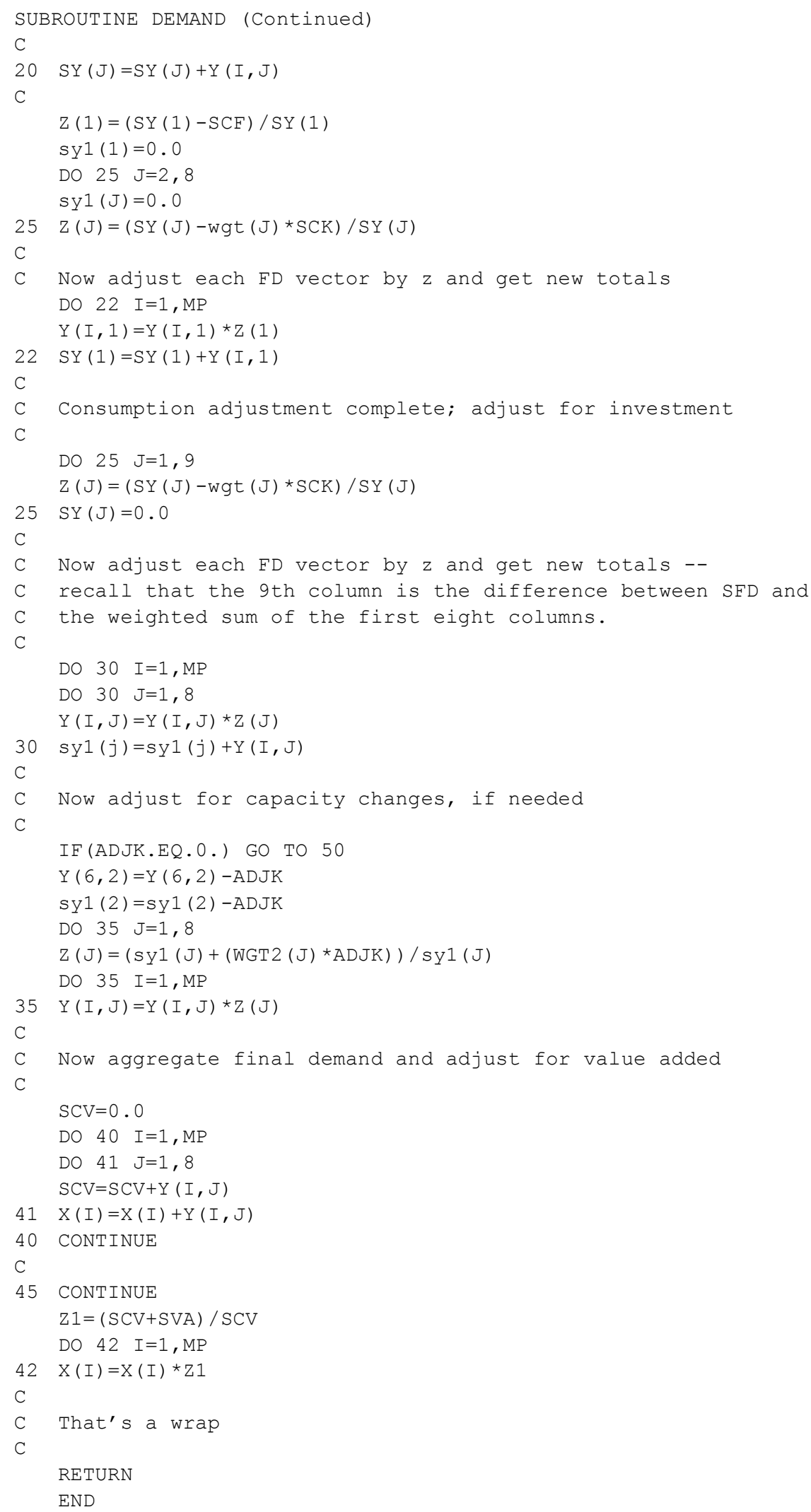

\section{14}

